\title{
An Overview of Geologic Carbon Sequestration Potential in California
}

CGS Special Report 183

\author{
Topical Report \\ West Coast Regional Carbon Sequestration Partnership \\ (WESTCARB) \\ Contract Period: October 1, 2003-September 30, 2005
}

Cameron Downey and John Clinkenbeard

September 30, 2005

DOE Contract No.: DE-FC26-03NT41984

\author{
Submitted by: \\ Larry Myer \\ PIER Program \\ California Energy Commission \\ 1516 Ninth Street, MS 43 \\ Sacramento, CA 95814 \\ Prepared by: \\ Cameron Downey and John Clinkenbeard \\ California Geological Survey \\ 801 K Street, MS 13-40 \\ Sacramento, CA 95814
}




\section{United States Government Disclaimer}

This report was prepared as an account of work sponsored by an agency of the United States Government. Neither the United States Government nor any agency thereof, nor any of their employees, makes any warranty, express or implied, or assumes any legal liability or responsibility for the accuracy, completeness, or usefulness of any information, apparatus, product, or process disclosed, or represents that its use would not infringe privately owned rights. Reference herein to any specific commercial product, process, or service by trade name, trademark, manufacturer, or otherwise does not necessarily constitute or imply its endorsement, recommendation, or favoring by the United States Government or any agency thereof. The views and opinions of authors expressed herein do not necessarily state or reflect those of the United States Government or any agency thereof.

\section{California Energy Commission Disclaimer}

This report was prepared as a result of work sponsored by the California Energy Commission (Energy Commission). It does not necessarily present the views of the Energy Commission, its employees, or the State of California. The Energy Commission, the State of California, its employees, contractors, and subcontractors make no warranty, express or implied, and assume no legal liability for the information in this report; nor does any party represent that the use of this information will not infringe upon privately owned rights. This report has not been approved or disapproved by the Energy Commission, nor has the Energy Commission passed upon the accuracy or adequacy of this information in this report.

\section{California Department of Conservation Disclaimer}

This report was prepared by the California Department of Conservation, California Geological Survey. The Department of Conservation makes no warranties as to the suitability of this product for any particular purpose. 


\begin{abstract}
As part of the West Coast Regional Carbon Sequestration Partnership (WESTCARB), the California Geological Survey (CGS) conducted an assessment of geologic carbon sequestration potential in California. An inventory of sedimentary basins was screened for preliminary suitability for carbon sequestration. Criteria included porous and permeable strata, seals, and depth sufficient for critical state carbon dioxide $\left(\mathrm{CO}_{2}\right)$ injection. Of 104 basins inventoried, 27 met the criteria for further assessment. Petrophysical and fluid data from oil and gas reservoirs was used to characterize both saline aquifers and hydrocarbon reservoirs. Where available, well log or geophysical information was used to prepare basin-wide maps showing depth-to-basement and gross sand distribution. California's Cenozoic marine basins were determined to possess the most potential for geologic sequestration. These basins contain thick sedimentary sections, multiple saline aquifers and oil and gas reservoirs, widespread shale seals, and significant petrophysical data from oil and gas operations. Potential sequestration areas include the San Joaquin, Sacramento, Ventura, Los Angeles, and Eel River basins, followed by the smaller Salinas, La Honda, Cuyama, Livermore, Orinda, and Sonoma marine basins. California's terrestrial basins are generally too shallow for carbon sequestration. However, the Salton Trough and several smaller basins may offer opportunities for localized carbon sequestration.
\end{abstract}




\section{Table of Contents}

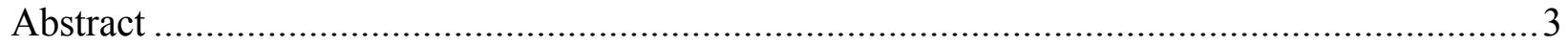

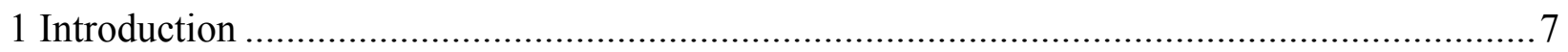

1.1 Background ................................................................................................. 7

1.2 The West Coast Regional Carbon Sequestration Partnership...................................... 8

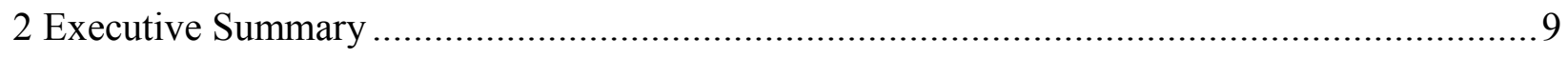

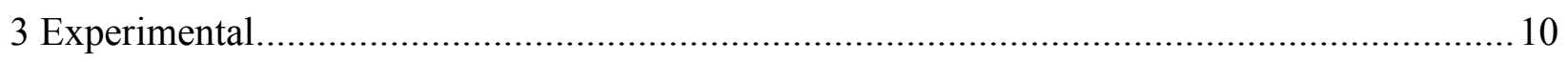

3.1 Scope of Investigation and Project Constraints .................................................. 10

3.2 Project Approach and Methods of Work ................................................................ 11

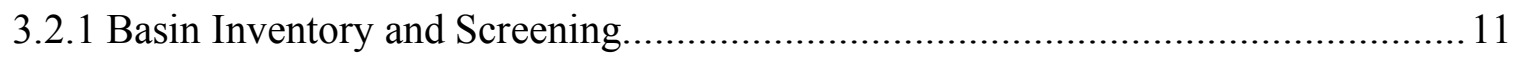

3.2.2 Oil \& Gas Reservoirs and Formation Properties ............................................... 12

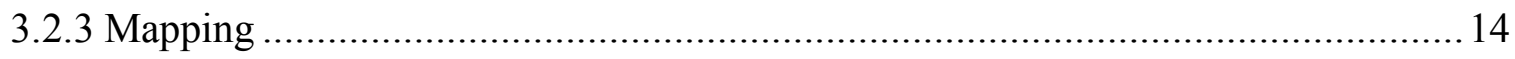

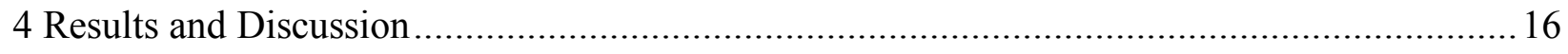

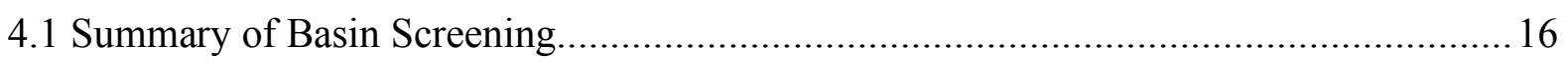

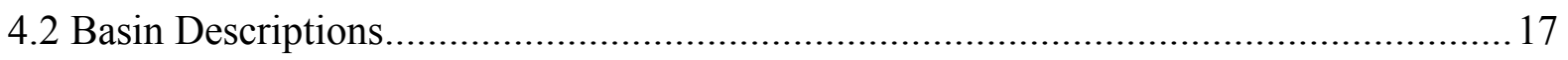

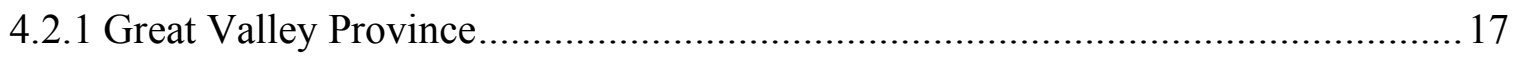

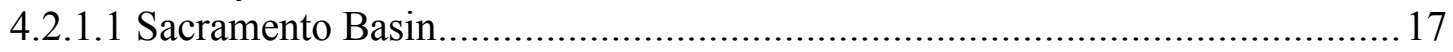

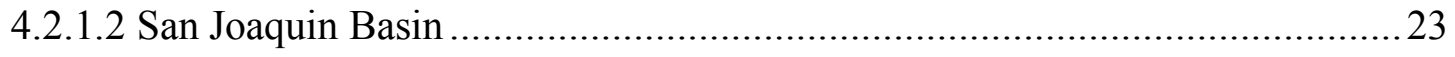

4.2.2 Transverse Ranges Province ....................................................................... 31

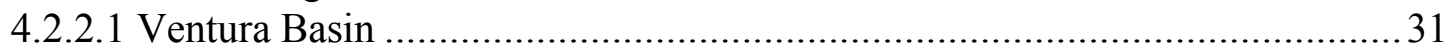

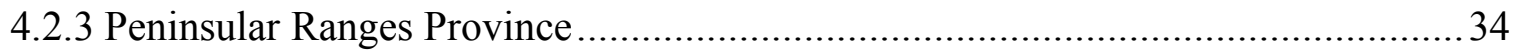

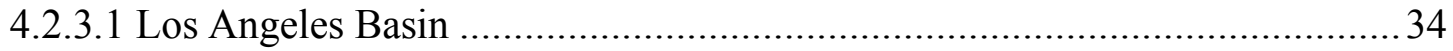

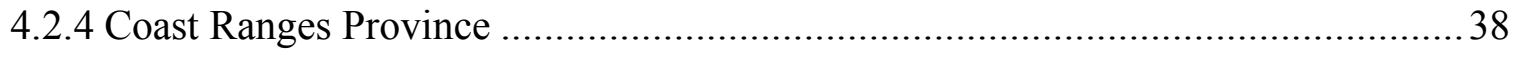

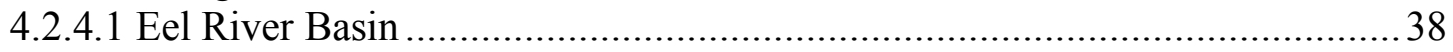

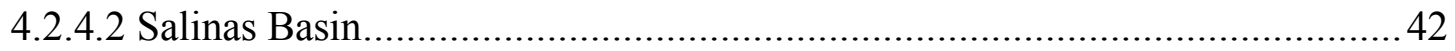

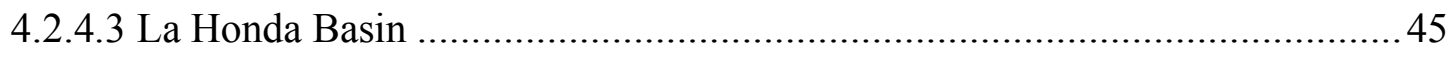

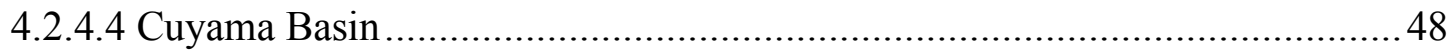

4.2.4.5 Livermore, Orinda, and Sonoma Basins .............................................. 50

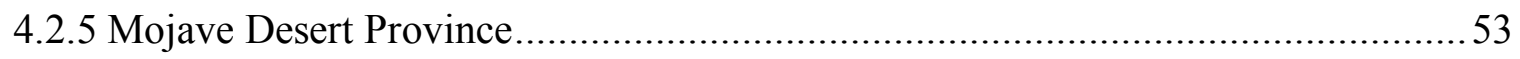

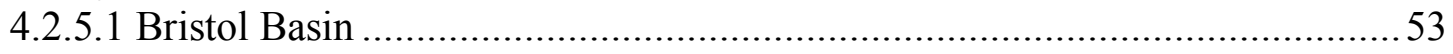

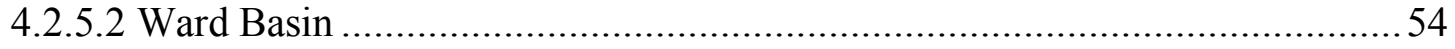

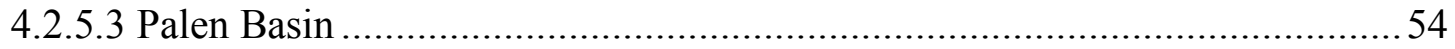

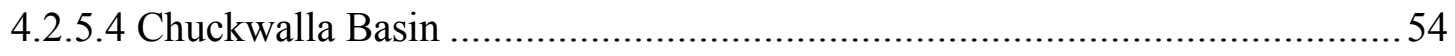

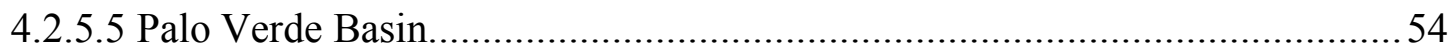

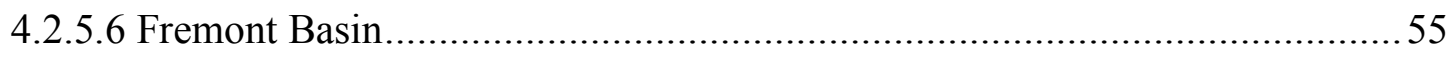

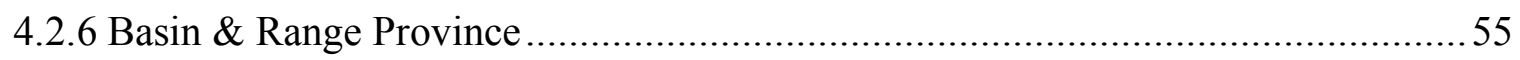

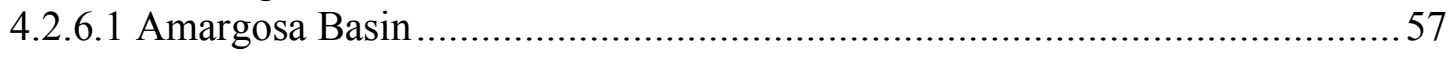

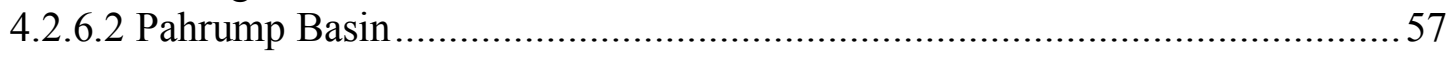

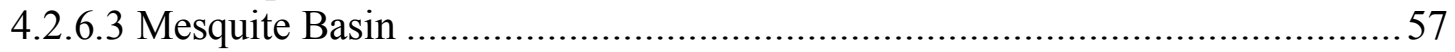

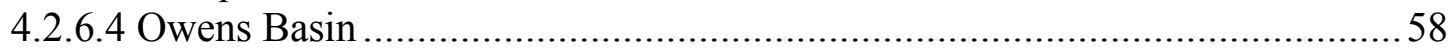

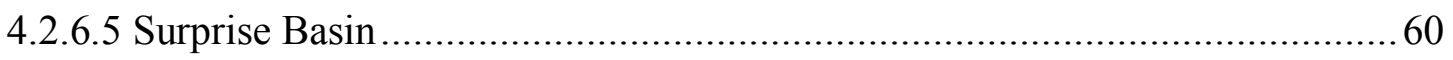

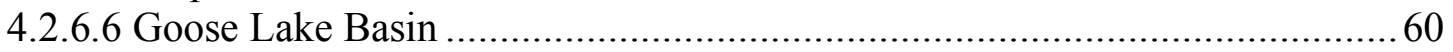




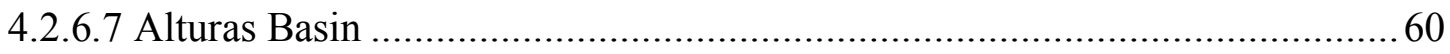

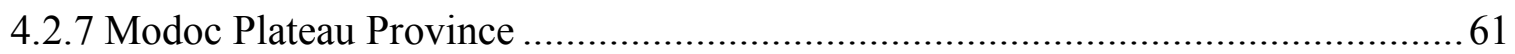

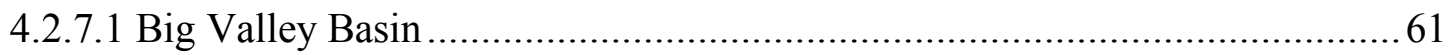

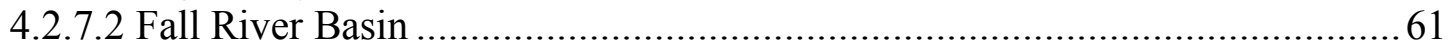

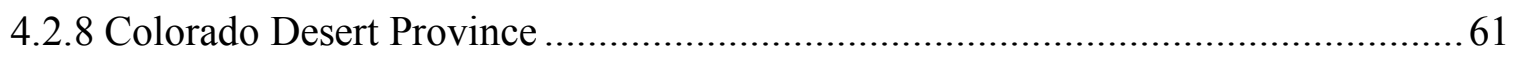

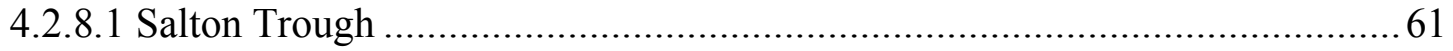

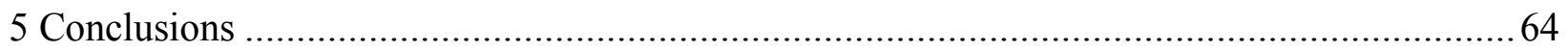

6 References

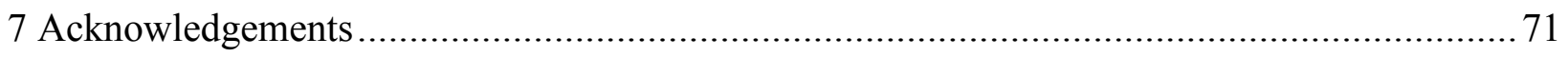

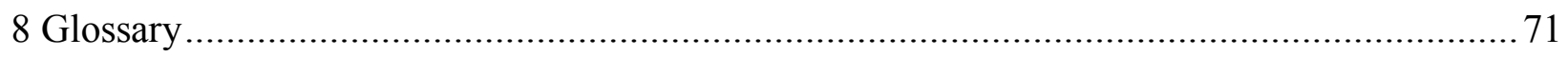

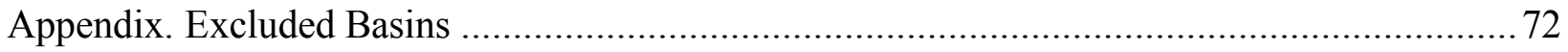

\section{List of Figures}

Figure 1. California sedimentary basins with oil and gas fields...............................................13

Figure 2. Sacramento and San Joaquin basins - depth-to-basement map...................................18

Figure 3. Sacramento and San Joaquin basins - gross sandstone isopach map for depth interval 800-3,050 m (2,625-10,000 ft; or basement).................................24

Figure 4. Ventura Basin - depth-to-basement map. ……....................................................... 31

Figure 5. Ventura Basin - gross sandstone isopach map for depth interval 800-

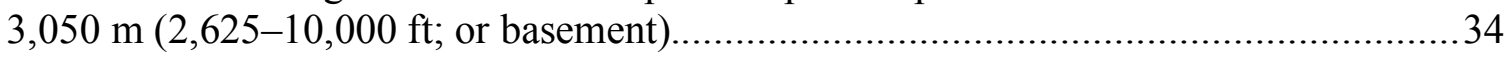

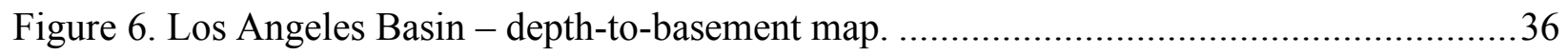

Figure 7. Los Angeles Basin - gross sandstone isopach map for depth interval 800-3,050 m (2,625-10,000 ft; or basement).......................................................... 39

Figure 8. Eel River Basin - depth-to-basement map............................................................. 41

Figure 9. Eel River Basin - gross sandstone isopach map for depth interval

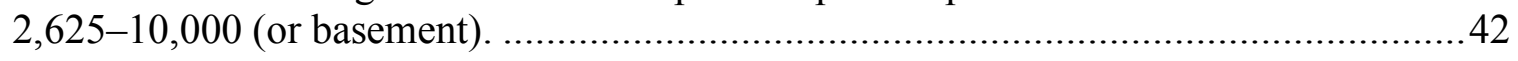

Figure 10. Salinas and La Honda basins - depth-to-basement map..........................................45

Figure 11. Salinas and La Honda basins - gross sandstone isopach map for

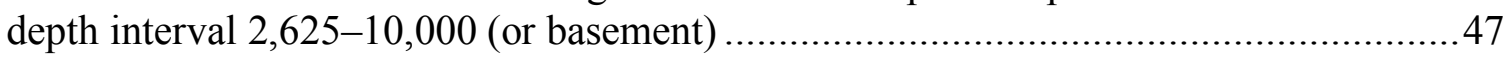

Figure 12. Cuyama Basin - gross sandstone isopach map for depth interval $800-3,050 \mathrm{~m}(2,625-10,000 \mathrm{ft}$; or basement).

Figure 13. Livermore and Orinda basins - gross sandstone isopach map for depth interval 800-3,050 m (2,625-10,000 ft; or basement)......................................52

Figure 14. Bristol, Ward, Palen, Chuckwalla, and Palo Verde basins - depth-

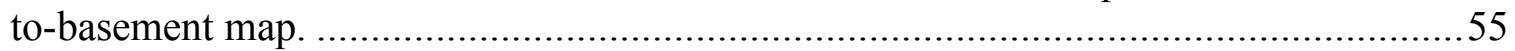

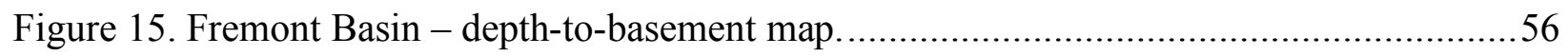

Figure 16. Amargosa, Pahrump, and Mesquite basins - depth-to-basement map. 
Figure 17. Owens Basin - depth-to-basement map. ...............................................5

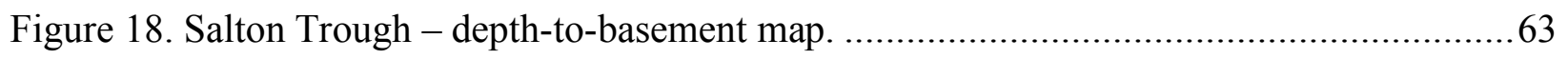

Figure 19. Salton Trough - gross sandstone isopach map for depth interval 800-3,050 m (2,625-10,000 ft; or basement).

\section{List of Tables}

Table 1. Sample content of a Field Table database record................................................. 14

Table 2. Sample content of a Zone Table database record.................................................... 15 


\section{Introduction}

As part of the West Coast Regional Carbon Sequestration Partnership (WESTCARB) Phase I effort, the California Department of Conservation, California Geological Survey (CGS) has developed preliminary baseline information concerning geologic options for carbon dioxide $\left(\mathrm{CO}_{2}\right)$ sequestration in California. This preliminary screening involved identifying and characterizing porous and permeable rock formations in the numerous sedimentary basins of California and defining areas within these basins that may be geologically suitable for storage of $\mathrm{CO}_{2}$. This information will be used by other members of WESTCARB in evaluating a variety of potential sequestration options for the WESTCARB region as a whole.

\subsection{Background}

Over the last several decades, concern has been raised over the potential impacts of anthropogenic greenhouse gasses on global climate (Hansen, 2004). Greenhouse gasses, such as $\mathrm{CO}_{2}$, trap infrared radiation that would otherwise escape into space and reflect it back to the Earth's surface in a manner similar to how a greenhouse traps infrared radiation that would otherwise be lost to the surrounding environment.

$\mathrm{CO}_{2}$ is a byproduct of the combustion of fossil fuels such as coal, oil, and natural gas. Its concentration in the atmosphere has been increasing since the Industrial Revolution. The increase in the concentration of $\mathrm{CO}_{2}$ in the atmosphere is projected to continue as the world's population increases and more countries become industrialized. The United States currently produces about $85 \%$ of its commercial energy with fossil fuels (Herzog and Golomb, 2004).

Slowing or reducing anthropogenic $\mathrm{CO}_{2}$ emissions to the atmosphere will be difficult and it is likely that multiple tactics will be needed to achieve this goal. Possible tactics for slowing or reducing $\mathrm{CO}_{2}$ emissions include:

- increasing the efficiency of power generation;

- using less carbon-rich fuels such as natural gas in place of oil or coal;

- using alternative energy sources such as solar, wind, or nuclear energy; and,

- carbon sequestration.

Carbon sequestration may play an important role in slowing anthropogenic-made $\mathrm{CO}_{2}$ emissions to the atmosphere in the near future. Carbon sequestration is the process of collecting $\mathrm{CO}_{2}$ emissions and isolating them from the atmosphere to prevent buildup of this greenhouse gas and its associated climatic effects. There are two broad categories of sequestration, terrestrial and geologic.

Terrestrial sequestration is achieved when plants absorb $\mathrm{CO}_{2}$ from the atmosphere during photosynthesis and incorporate the carbon into their structure or transfer it to the soil. Changing the way that forests, rangeland, agricultural lands, and wetlands are managed to either increase the amount of $\mathrm{CO}_{2}$ removed from the atmosphere and stored as biomass, or decrease the $\mathrm{CO}_{2}$ emissions from these areas is one way of reducing atmospheric $\mathrm{CO}_{2}$. Terrestrial sequestration can isolate $\mathrm{CO}_{2}$ from the atmosphere for decades. 
Geologic sequestration involves capturing $\mathrm{CO}_{2}$ from point sources such as power plants and industrial facilities and storing it in geologic formations. This can be achieved in several ways including injection into depleted or abandoned oil or gas reservoirs or deep saline aquifers; injection into deep, unmineable coal beds; or conversion to carbonate minerals by reaction with ultramafic rocks or serpentinite. Geologic sequestration has the potential to isolate $\mathrm{CO}_{2}$ from the atmosphere over very long timeframes ranging from hundreds to thousands of years or longer.

\subsection{The West Coast Regional Carbon Sequestration Partnership}

Myer and Birkinshaw (2005) describe WESTCARB and its goals as follows:

"The West Coast Regional Carbon Sequestration Partnership is one of seven partnerships that have been established by the U.S. Department of Energy (DOE) to evaluate carbon capture and sequestration (CCS) technologies best suited for different regions of the country. The West Coast Region includes Arizona, California, Nevada, Oregon, Washington, and the North Slope of Alaska. Led by the California Energy Commission, West Coast Regional Carbon Sequestration Partnership is a consortium of over 35 organizations, including state natural resource and environmental protection agencies; national laboratories and universities; private companies working on $\mathrm{CO}_{2}$ capture, transportation, and storage technologies; utilities; oil and gas companies; nonprofit organizations; and policy/governance coordinating organizations. In an 18-month Phase I project, the Partnership will evaluate both terrestrial and geologic sequestration options. Work will focus on five major objectives:

1. Collect data to characterize major $\mathrm{CO}_{2}$ point sources, the transportation options, and the terrestrial and geologic sinks in the region, and then compile and organize this data via a geographic information system (GIS) database.

2. Address key issues affecting deployment of CCS technologies, including storage-site permitting and monitoring, injection regulations, and health and environmental risks.

3. Conduct public outreach and maintain an open dialogue with stakeholders in CSS technologies through public meetings, joint research, and education work.

4. Integrate and analyze data and information from the above tasks to develop supply curves and cost-effective, environmentally acceptable sequestration options, both near and long term.

5. Identify appropriate terrestrial and geologic demonstration projects consistent with the options defined above, and create action plans for their safe and effective implementation."

Additional information on WESTCARB can be found on its web page at http://www.westcarb.org. 


\section{Executive Summary}

As part of the West Coast Regional Carbon Sequestration Partnership, the California Geological Survey (CGS) conducted a preliminary assessment of geologic carbon sequestration potential in California. This involved identifying and characterizing porous and permeable rock formations and defining areas within the state's sedimentary basins that may be geologically suitable for carbon sequestration in saline aquifers or producing or abandoned oil and gas reservoirs. Information was compiled in digital and GIS formats to facilitate spatial analysis and use by other partnership participants.

The CGS identified and cataloged sedimentary basins within California's 11 geomorphic provinces. Inventoried basins included all large or hydrocarbon-producing marine basins, as well as other smaller basins identified from the statewide geologic map of California. The resulting 104 basins were screened to determine preliminary suitability for carbon sequestration. Criteria included the presence of significant porous and permeable strata, seals, and sediment thickness sufficient for critical state carbon dioxide injection. Of the 104 basins, 27 met the criteria for further assessment.

Since saline aquifers have little economic value, no quantitative data is available to measure their capacity for sequestration. To characterize the physical rock and fluid properties of both saline aquifers and hydrocarbon reservoirs, oil and gas field reservoir data was assembled from publications of the California Division of Oil, Gas, and Geothermal Resources and other available sources. Data compiled included location, depth, field area, cumulative production, and depth to base of fresh water. In basins containing oil or gas reservoirs, physical rock and fluid properties for each reservoir unit within each field were compiled. These data included reservoir fluid, zone status, average depth, average thickness, producing area, porosity, permeability, initial pressure and temperature, formation water salinity, seal thickness, trap type, and history of secondary and tertiary recovery efforts. These data were used to characterize rock and fluid properties and evaluated to identify potential saline aquifers and reservoirs for carbon sequestration. Where adequate well bore or geophysical information was available, basin-wide maps showing depth-to-basement and gross sand distribution were prepared to identify promising areas for carbon sequestration.

This preliminary assessment indicates that California's Cenozoic marine sedimentary basins possess the most potential for geologic carbon sequestration. As a group, these basins exhibit a widespread areal distribution, thick sedimentary sections containing multiple widespread saline aquifers and oil and gas reservoirs, thick and laterally persistent shale seals, and an abundance of petrophysical data available through oil and gas development. The most promising basins include the San Joaquin, Sacramento, Ventura, Los Angeles, and Eel River basins. Smaller marine basins, including the Salinas, La Honda, Cuyama, Livermore, Orinda, and Sonoma basins, are also promising but more restricted in terms of size and available geological information. California's terrestrial basins are generally too shallow for carbon sequestration. However, the large Salton Trough and several smaller terrestrial basins may offer some opportunities for localized carbon sequestration and cannot be excluded from consideration given the limited currently available information. Additional geological information and characterization of these basins will be required before their sequestration potential can be more accurately assessed. 


\section{Experimental}

\subsection{Scope of Investigation and Project Constraints}

The CGS's role in Phase I involved the preliminary screening and inventorying of potential sites for geologic $\mathrm{CO}_{2}$ sequestration. The goal was to provide baseline geologic data and identify potentially suitable areas for geologic sequestration in California. This involved evaluating the $\mathrm{CO}_{2}$ sequestration potential of sedimentary rock units within California's many sedimentary basins.

The decision to focus this initial study on the evaluation of California's sedimentary basins was based on the state's geology and the current state of sequestration technology. Currently, three major methods of geologic carbon sequestration are being studied:

- Injection into deep, unmineable coal beds,

- Conversion to carbonate minerals by reaction with ultramafic rocks or serpentinite, and

- Injection of $\mathrm{CO}_{2}$ into depleted or abandoned oil or gas reservoirs or deep saline aquifers.

While coal has been mined in California in the past, mostly prior to 1900, the state has only scattered coal occurrences. Most are of limited extent and low grade, making them unlikely targets for sequestration.

Ultramafic rock and serpentinite make up approximately $1.4 \%$ of the state's area and are most common in the foothills of the Sierra Nevada, the Coast Ranges, and northwestern California. While the processes of converting ultramafic rock or serpentinite to carbonate minerals (mineral carbonation) occur in nature (Hansen and Dipple, 2005) and has been proposed as a means of carbon sequestration (Goff and Lackner, 1998; Eilperin, 2005), a cost effective commercial process for mineral carbonation is still being researched and has yet to be demonstrated.

California has numerous sedimentary basins containing saline aquifers and/or oil or gas fields. An initial evaluation identified 104 sedimentary basins making up approximately $33 \%$ of the area of the state. These basins contain 465 oil and gas fields for which varying amounts of subsurface geological and petrophysical information are available to aid in the evaluation of sequestration potential.

California's geology is complex owing to its history as a convergent continental margin. Accordingly, a systematic effort to map the many potential sequestration horizons or associated seals was beyond the scope of this effort. Rather, the goal of the investigation was to provide a timely preliminary screening of California's sedimentary basins.

Subsurface sequestration in sedimentary rocks can be accomplished through $\mathrm{CO}_{2}$ injection into saline aquifers, or where conditions permit, injection into idle or abandoned oil and gas fields. Carbon dioxide injection as a form of Enhanced Oil Recovery (EOR) in producing oil fields has been in use for many years. In a typical EOR operation, some of the injected $\mathrm{CO}_{2}$ is recovered at the surface with the oil produced. It is possible that an EOR operation could be designed to increase the amount of $\mathrm{CO}_{2}$ that would remain in the geologic reservoir while still enhancing the 
production of oil, and possibly natural gas.

Saline aquifers have little economic value and are seldom the objective of exploration or production drilling. Hence, while they are of considerable interest for potential $\mathrm{CO}_{2}$ sequestration, little is known about their direct petrophysical properties on a regional level. Since hydrocarbon accumulations frequently occur in localized structural and/or stratigraphic traps within saline aquifers, information obtained through geophysical logging, coring, and production testing of oil and gas reservoirs gives us our best insights into the potential properties of saline aquifers as a whole. Recognizing that geologic units are heterogeneous and petrophysical properties may vary considerably within a given aquifer, oil and gas reservoir data was used as a surrogate for characterizing stratigraphically correlative saline aquifers for the purposes of this appraisal. Physical rock and fluid data for depleted and producing oil and gas reservoirs used in this investigation were taken largely from publications of the California Department of Conservation, Division of Oil, Gas, and Geothermal Resources (DOGGR).

In most of California's mature hydrocarbon producing basins, geophysical well log control is usually sufficient to identify and map porous and permeable sandstones and sealing shales. However, in some basins where oil and gas production is limited or absent, subsurface control may be limited or absent. This is evident in the nonmarine basins of the Mojave Desert and Basin and Range provinces, where only regional gravity data was available to provide some measure of basin depth in many cases.

\subsection{Project Approach and Methods of Work}

\subsubsection{Basin Inventory and Screening}

The CGS identified and cataloged sedimentary basins within California's 11 geomorphic provinces. Selected basins included all large or hydrocarbon producing basins as well as numerous smaller basins identified from the 1:750,000 scale geologic map of California (Jennings et al., 1977). Where basins extended offshore, only the onshore portions were considered. This resulted in an inventory of 104 basins, outlines of which were digitized to produce a California sedimentary basin GIS layer. This layer was combined with a California oil and gas field layer to illustrate the distribution of known oil and gas fields (Figure 1). Basins were screened to determine preliminary suitability for potential $\mathrm{CO}_{2}$ sequestration, with those basins not meeting the screening criteria being excluded from further consideration. Screening involved literature searches and analysis of available well logs. Criteria included the presence of significant porous and permeable strata, thick and pervasive seals, and sufficient sediment thickness to provide critical state pressures for $\mathrm{CO}_{2}$ injection ( $>800 \mathrm{~m}$ or 2,625 ft)). Accessibility was also considered, with basins overlain by national and state parks and monuments, wilderness areas, Bureau of Indian Affairs administered lands, and military installations being excluded. Most of the basins excluded for this reason are located in the arid desert valleys of the Basin and Range and Mojave Desert geomorphic provinces.

Almost all saline aquifers and oil and gas reservoirs in California are relatively young (upper Cretaceous - Pleistocene in age) and exhibit relatively high porosities and a wide range of permeabilities. Therefore, no constraints were placed on these parameters with the exception of fractured saline aquifers or reservoirs, which were considered poor candidates for sequestration. 
For this reason, the Santa Maria Basin, in which most porosity and permeability occurs in fractured Miocene shale, was excluded from further consideration at this time.

Finally, structural closure or stratigraphic trapping was not considered a prerequisite for saline aquifers at the screening level. Generally, hydrodynamic forces and fluid residence times within regional saline aquifers may be sufficient to effectively trap $\mathrm{CO}_{2}$ for hundreds or thousands of years in the larger and more regional aquifers. Reliability of hydrodynamic containment in smaller basins where outcrop recharge areas are nearby may be considerably less.

\subsubsection{Oil and Gas Reservoirs and Formation Properties}

To characterize potential saline aquifers and hydrocarbon reservoirs, oil and gas field and reservoir data was assembled for depleted and producing fields from publications of the DOGGR and other available sources. Data was occasionally inconsistent or inaccurate. Where it could be determined with certainty, inaccurate data was omitted. Also, rock properties such as porosity and permeability are often reported as measured, average, calculated, or estimated values. No effort was made to standardize these data. 


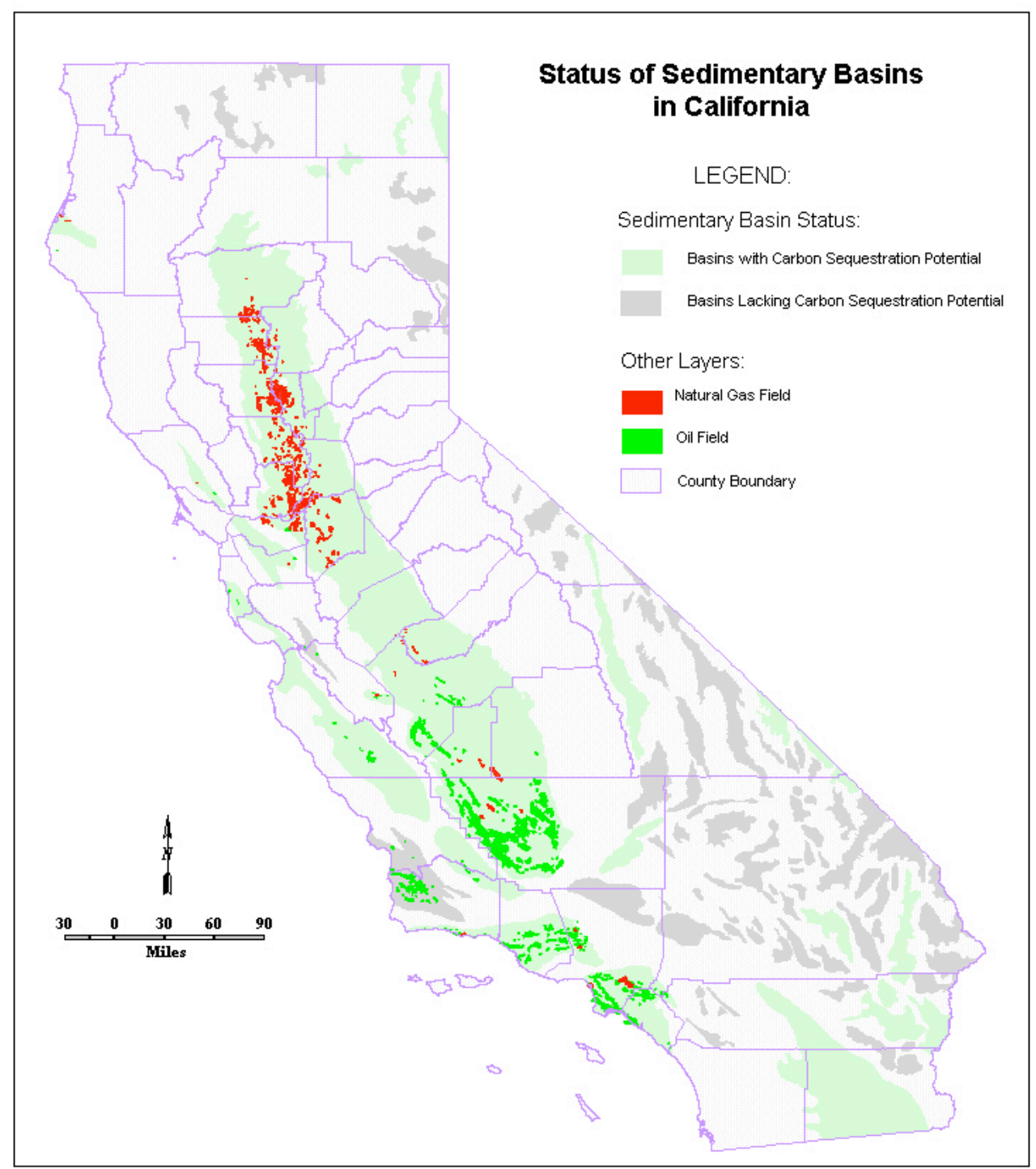

Figure 1. California sedimentary basins with oil and gas fields

Data was compiled in field-level and reservoir-level databases and attributed to the California oil and gas field GIS layer for manipulation and spatial analysis by other WESTCARB participants. Field level data included information such as location, depth, field area, cumulative production, and depth to base of fresh water. Field level database parameters are shown in Table 1.

Reservoir-specific parameters for producing, abandoned, or shut-in reservoirs in each field were compiled in the reservoir level database. These data included reservoir fluid (oil, gas, water), zone status (producing, abandoned, shut-in), average depth, average thickness, producing area, porosity, permeability, initial pressure and temperature, formation water salinity, seal thickness, trap type (structural or stratigraphic), and history of secondary and tertiary recovery efforts. A measure of "fracture intensity" was assigned for most reservoirs to instill a general sense of fracturing and/or faulting. This subjective measure was assigned a value of Low, Medium, and 
High, based solely on the number of mapped faults illustrated in published DOGGR field maps ( $\mathrm{L}=0-1$ fault; $\mathrm{M}=2-3$ faults; $\mathrm{H}=4+$ faults). An example of reservoir database parameters is shown in Table 2.

Table 1. Sample content of a Field Table database record

\begin{tabular}{|ll|}
\hline Field Code: & VE024 \\
Field: & Honor Rancho Oil \\
Discovery Well Operator: & The Texas Co. \\
Discovery Well: & Honor Rancho A -1 \\
Section: & 6 \\
Township: & $4 \mathrm{~N}$ \\
Range: & $16 \mathrm{~W}$ \\
Meridian: & SB \\
Discovery Date: & $8 / 1 / 1950$ \\
Deepest Well Operator: & So. California Gas Co. \\
Deepest Well: & Wayside Unit 28 \\
Section: & 7 \\
Township: & $4 \mathrm{~N}$ \\
Range: & $16 \mathrm{~W}$ \\
Meridian: & SB \\
Depth & $11,747 \mathrm{ft}$. \\
Field Area & 450 acres \\
Cum. Oil Prod. (MBO) & 31,098 \\
Cum. Gas Prod. (MMCF) & 52,992 \\
Base Fresh Water: & $1,150 \mathrm{ft}$. \\
\hline
\end{tabular}

\subsubsection{Mapping}

Sufficient burial depth to ensure critical state injection pressures for carbon dioxide is an important prerequisite for subsurface $\mathrm{CO}_{2}$ sequestration. The minimum depth is generally accepted to be $800 \mathrm{~m}(2,625 \mathrm{ft})$. Some of California's oil and gas producing Cenozoic marine basins contain sufficient well control to allow regional subsurface mapping. To identify areas of adequate sedimentary fill, depth-to-basement contour maps were prepared for those basins containing sufficient basement penetrations. This included the Sacramento, San Joaquin, and Salinas basins. In some producing basins, where basement well control is limited or absent, basement contour maps were extrapolated from shallower structure maps (Eel River Basin) or published geophysical depth-to-basement maps were used (Los Angeles, Ventura Basins). In other producing basins, no deep well log or geophysical data was available, and depth-tobasement maps could not be prepared.

In non-producing basins (generally Cenozoic terrestrial basins), basement well control is rarely available, and depth-to-basement maps were almost exclusively adapted from the published gravity based depth-to-basement maps. Since these maps used a 1-kilometer contour interval, for 
the sake of convenience, basins with less than 1 kilometer (rather than 800 meters) of fill were excluded. This had the effect of eliminating a number of remote shallow terrestrial basins that might have slightly more than minimum fill, while retaining those that more clearly contained thicker sedimentary sequences. Gravity depth-to-basement maps were the primary source for depth information in the Salton Trough and the numerous basins of the Mojave Desert and Basin and Range provinces.

Table 2. Sample content of a Zone Table database record

\begin{tabular}{|c|c|c|c|}
\hline Field Code: & VE024 & Perm.: & $20 \mathrm{md}$ \\
\hline Zone: & Modelo Fm. & Perm. Range Min.: & $179 \mathrm{md}$ \\
\hline Age: & U. Miocene & Perm. Range Max.: & \\
\hline Oil or Gas: & $\mathrm{O}$ & Pressure: & $2,962 \mathrm{lb} / \mathrm{ft}^{2}$ \\
\hline Date of Discovery: & $12 / 1 / 1950$ & Press. Range Min.: & $4,500 \mathrm{lb} / \mathrm{ft}^{2}$ \\
\hline Zone Status $(\mathrm{P} / \mathrm{A} / \mathrm{SI})$ : & $\mathrm{P}$ & Press. Range Min.: & $190 \mathrm{lb} / \mathrm{ft}^{2}$ \\
\hline API Gravity: & & Temperature: & \\
\hline API Range Min.: & 35 & Temp. Range Min.: & \\
\hline $\begin{array}{l}\text { API Range Max.: } \\
\text { GOR: }\end{array}$ & 39 & $\begin{array}{l}\text { Temp. Range Max.: } \\
\text { Salinity: }\end{array}$ & \\
\hline GOR Range Min.: & 220 & Sal. Range Min.: & $\begin{array}{l}11,200 \mathrm{ppm} \\
\mathrm{NaCl}\end{array}$ \\
\hline GOR Range Max.: & 1,250 & Sal. Range Max.: & $\begin{array}{l}24,800 \mathrm{ppm} \\
\mathrm{NaCl}\end{array}$ \\
\hline Sp. Gravity: & & TDS: & $\begin{array}{l}20,200 \mathrm{ppm} \\
\mathrm{NaCl}\end{array}$ \\
\hline Sp. Gravity Min.: & 0.470 & TDS Range Min.: & \\
\hline Sp. Gravity Max.: & 0.765 & TDS Range Max.: & \\
\hline BTU: & 1,066 & Seal: & Modelo Fm. \\
\hline BTU Range Min.: & & Seal Thickness: & \\
\hline BTU Range Max.: & & Seal Thickness Min.: & $5 \mathrm{ft}$. \\
\hline Cum. Oil (MBO): & 29,094 & Seal Thickness Max.: & $50 \mathrm{ft}$. \\
\hline Cum. Gas (MMCF): & 47,601 & Trap Type: & Stratigraphic \\
\hline No Pool Breakdown: & & Fault Intensity: & $\mathrm{L}$ \\
\hline Depth: & & ERP 1: & Gas Injection \\
\hline Depth Range Min.: & $6,481 \mathrm{ft}$. & ERP 1 Start: & 1954 \\
\hline Depth Range Max.: & $10,000 \mathrm{ft}$. & ERP 1 Stop: & 1956 \\
\hline Thickness: & & ERP 2: & Waterflood \\
\hline Thickness Range Min.: & $94 \mathrm{ft}$. & ERP 2 Start: & 1959 \\
\hline Thickness Range Max.: & $310 \mathrm{ft}$. & ERP 2 Stop: & 1966 \\
\hline Producing Area: & 400 acres & ERP 3: & Waterflood \\
\hline Porosity (\%): & & ERP 3 Start: & 1972 \\
\hline $\begin{array}{l}\text { Porosity Range Min. } \\
(\%) \text { : }\end{array}$ & 7 & ERP 3 Stop: & 1975 \\
\hline $\begin{array}{l}\text { Porosity Range Max. } \\
(\%) \text { : }\end{array}$ & 26 & & \\
\hline
\end{tabular}


The reconnaissance nature of this study precluded a systematic effort to map the many potential aquifers, reservoirs, or sealing formations, or, to prepare basin-wide sand-shale ratio maps. Instead, to identify areas of thick sand development in basins with adequate well log control, a single gross sandstone isopach map was constructed for the interval between 800 and 3,050 m $(2,625$ and 10,000 ft) (or basement if shallower than 3,050 $\mathrm{m}(10,000 \mathrm{ft}))$. The upper isopach limit comprises the minimum depth for critical state $\mathrm{CO}_{2}$ injection, while the lower limit was selected to incorporate a reasonable number of deeper well logs in the larger Sacramento, San Joaquin, Los Angeles, and Ventura basins. While this approach lumps many disparate sand bodies and is not accurate from a rock, time, or sequence stratigraphic standpoint, it does provide a broad measure of the more sand-rich areas.

\section{Results and Discussion}

\subsection{Summary of Basin Screening}

Screening and follow-up geologic reviews resulted in 27 of the original 104 basins being identified as having geologic sequestration potential. The remaining 77 basins failed to meet at least one of the screening criteria. Most of these basins are shallow nonmarine basins that lack sufficient fill, are too small, or are overlain by national parks, military installations, or Indian reservations. The majority of these basins are located in the arid desert regions of the Mojave Desert and Basin and Range provinces. A table listing each excluded basin and the basis for each determination is attached as Appendix A.

Of the 27 basins which met the screening criteria, the most promising are the larger Cenozoic marine basins, including the San Joaquin, Sacramento, Los Angeles, Ventura, and Salinas basins, followed by the smaller Eel River, La Honda, Cuyama, Livermore, and Orinda marine basins. Favorable attributes of these basins include (1) geographic diversity; (2) thick sedimentary fill with multiple porous and permeable aquifers and hydrocarbon reservoirs; (3) thick, laterally persistent marine shale seals; (4) locally abundant geological, petrophysical, and fluid data from oil and gas operations; and (5) numerous abandoned or mature oil and gas fields which might be reactivated for $\mathrm{CO}_{2}$ sequestration or benefit from $\mathrm{CO}_{2}$ enhanced recovery operations. Most of these basins contain multiple oil and gas reservoirs and saline aquifers that met the initial screening criteria, the most important of which are discussed in the following sections. The zones were selected for their greater areal distributions and/or thicknesses, significant sealing formations, and hydrocarbon production.

Additionally, a number of nonmarine Cenozoic basins were determined to have variable sequestration potential. Since nonmarine basins are generally hydrocarbon poor, little subsurface well information is available making a stratigraphic or petrophysical assessment of a basin's saline aquifers impossible. However, in most cases, geophysical data was available to ascertain depth-to-basement and identify those basins containing sufficient sedimentary fill to meet the minimum depth requirement. Where available, shallow well or outcrop information was used to supplement the depth determinations, but in general, subsurface geology remains unknown. Much more information is needed to properly assess the sequestration potential of all the identified nonmarine basins, including the large Salton Trough. 
Final selection of a sequestration site in any of these basins would require more detailed, sitespecific, analysis of the geologic characteristics of the site and subsurface. Additionally, detailed analyses of permitting issues, monitoring system design, potential health and environmental risks, transportation issues, and economics will need to be performed prior to operation of a sequestration project.

The following section describes the 27 basins that met the initial geologic screening criteria in this study.

\subsection{Basin Descriptions}

\subsubsection{Great Valley Province}

The Great Valley province is an elongate topographic valley approximately $725 \mathrm{~km}$ (450 mi.) long lying between the Sierra Nevada and the Coast Ranges, and extending from the Klamath Mountains in the north to the Transverse Ranges in the south. The Great Valley consists of a large depositional basin that has received sediments almost continuously since the late Jurassic and contains, by some estimates, as much as 12,195 m (40,000 ft) of mostly marine, sedimentary rocks (Magoon and Valin, 1995). In the subsurface, the Great Valley is divided into the Sacramento Basin on the north and the San Joaquin Basin to the south, the point of division being the buried Stockton Arch south of the City of Stockton. Due to Cenozoic regional uplift of the northern Great Valley, Miocene through Pliocene strata has been stripped from all but the southernmost Sacramento Basin.

\subsubsection{Sacramento Basin}

The Sacramento Basin measures approximately $386 \mathrm{~km}$ (240 mi.) long and averages about 81 $\mathrm{km}$ (50 mi.) wide. In contrast to the oil-prone San Joaquin Basin, the Sacramento Basin is a natural gas-producing basin. It includes the state's largest natural gas field, the Rio Vista Field, which has produced more than $99 \mathrm{Gm}^{3}$ gas (3.5 TCFG, or trillion cubic feet of gas).

In conjunction with the northern San Joaquin Basin, the Sacramento Basin formed as part of an upper Jurassic-Paleogene forearc basin between the Sierra magmatic arc and the Franciscan subduction complex to the west. During the upper Jurassic through Cretaceous, the basin filled with a thick sequence of marine slope and submarine fan facies and fringing prograding shelf, deltaic, and nonmarine facies derived largely from the Sierran arc. This sequence is collectively called the Great Valley Sequence. On the eastern side of the basin the rocks are largely shallow marine and deltaic deposits whereas farther basinward, sediments are dominated by deep marine shale and basin plain turbidite deposits.

In its current form, the basin comprises an asymmetric trough with a westerly dipping basement surface ranging from surface exposures in the Sierra foothills to depths estimated to be greater than 6,710 m (22,000 ft) (Figure 2). The western flank is structurally complex, its dominant features being the westerly dipping Coast Range Thrust Fault, numerous associated faults, and steeply dipping beds. 
The lowermost upper Cretaceous formations in the basin, the Sites, Guinda, and Dobbins formations, are dominantly basin plain shales in which sandstones are scarce. The oldest sandstones that might be considered for $\mathrm{CO}_{2}$ sequestration are those of the upper Cretaceous Forbes Formation, which was deposited as a southward prograding, mud rich, basin plain-deep sea fan and slope turbidite system (Imperato et al., 1990). It outcrops on the west side of the basin in the foothills of the Coast Ranges and onlaps Sierran granitic basement to the east. In the southern part of the basin, the Forbes beds plunge below a thickening wedge of younger Cretaceous and Tertiary rocks.

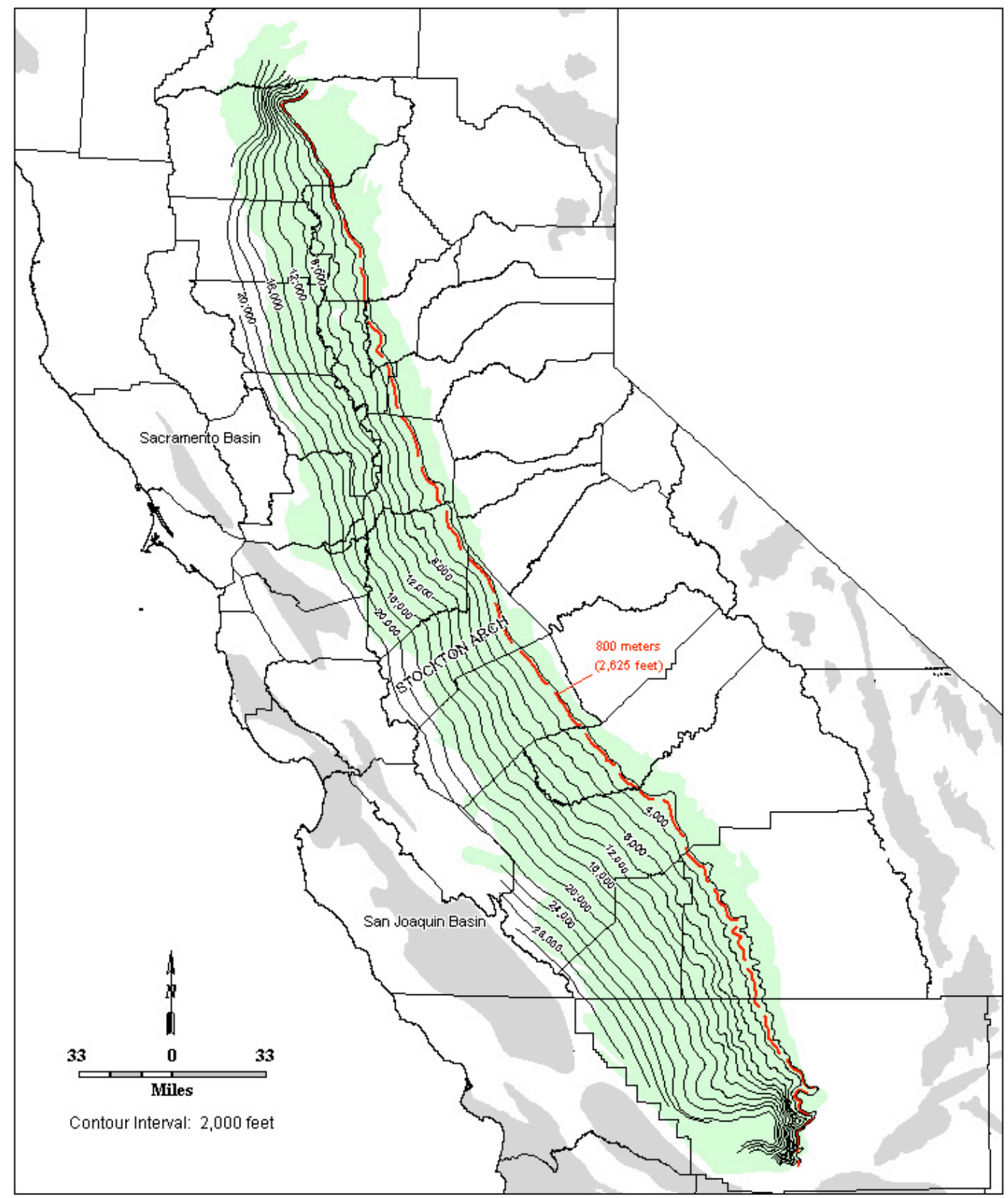

Figure 2. Sacramento and San Joaquin basins - depth-to-basement map. 
Forbes Formation sandstones are highly lenticular and erratic in distribution. Sand bodies represent turbidite channel, channel levee, and fan lobes enveloped in surrounding marine shale. Sandstone reservoirs are often measured in tens or hundreds of acres and are frequently absent in closely spaced offsetting wells. Vertical stacking of multiple reservoirs is often responsible for considerable gas reserves. Forbes Formation producing fields include the state's second largest gas field, Grimes Field, in which a number of individual sand bodies have collectively produced over $18.1 \mathrm{Gm}^{3}$ gas (638 BCFG, or billion cubic feet of gas). Sandstones are typically a few feet to a few hundred feet) thick. Depths range from about $610 \mathrm{~m}(2,000 \mathrm{ft})$ in the north basin and in the vicinity of the Sutter Buttes in Sutter County, to deeper than 3,384 m (11,100 ft) in Solano County. Porosities generally range between 15-30 percent with permeabilities in the range of $1.5 \times 10^{-14}$ to $1.1 \times 10^{-13} \mathrm{~m}^{2}$ (15-108 millidarcies (md)) (DOG, 1983).

The upper Cretaceous Kione Formation consists of a sequence of deltaic sandstones that prograded to the south and west over the Forbes Formation slope and turbidite deposits. Kione sandstones are present throughout much of the basin, but grade southward into distal prodeltaic mud and shale in southern Colusa County. To the north, in parts of Tehama County, the Kione Formation is truncated by regional angular unconformity. Kione sandstones are also absent in a northeast - southwest trend extending from eastern Tehama County through Yolo County where they have been eroded and replaced by mudstone infilling of the Paleocene Princeton Submarine Canyon.

With the exception of a narrow corridor along the basin axis, Kione sandstones are too shallow for carbon sequestration. Sandstone facies reach a maximum depth of between 1,370 and 1,525 $\mathrm{m}(4,500$ to $5,000 \mathrm{ft})$ in southern Colusa County before shaling out. Individual sandstones range from a few $\mathrm{cm}$ (several in.) to over $100 \mathrm{~m}$ (several hundred feet) thick with aggregate thicknesses upwards of $600 \mathrm{~m}$ (2,000 ft). High porosities between 25-35 percent are common (DOG, 1983). Seals may be thin interbedded Kione shales or the overlying regionally transgressive Sacramento Shale, which can approach $90 \mathrm{~m}$ (300 ft) thick. Locally, variable thicknesses of mudstone fill provide seals along the flanks of the Princeton Submarine Canyon.

Gas accumulations in the Kione are generally small and occur in small closures, fault traps, and stratigraphic traps where Kione sandstones have been truncated by regional unconformity or erosion by the Princeton Canyon. The largest field, from a production standpoint, is Wild Goose Gas Field which produced $2.94 \mathrm{Gm}^{3}$ gas (104 BCFG) from twelve Kione sandstones on a structural closure of less than 320 acres. The field was converted to a natural gas storage field in 1998.

The upper Cretaceous Lathrop, Winters, Tracy, Blewett, and Starkey formations are genetically related units, sometimes collectively called the Panoche Formation. They record a renewed progradational sequence of basin filling overlying the Sacramento Shale. Each unit is separated by regionally extensive marine shale. The Lathrop, Winters, Blewett, and Tracy formations consist of separate sand-rich submarine fan, slope, and basin plain sediments that were delivered to the shelf edge by multiple prograding Starkey Formation deltaic complexes. The Starkey Formation can be divided into at least six deltaic cycles (Moore and Nilsen, 1990). Lateral migration of the prograding deltas resulted in differing spatial distributions and stratigraphic 
position of the submarine fans ranging from the lowermost Lathrop fan through the uppermost Blewett fan.

Lathrop sandstones are time equivalent with the lower Winters sandstones, but occur farther south with little overlap. A lower Starkey delta system provided sands to the Lathrop fans, which were the earliest to be deposited over the Sacramento Shale in the southern Sacramento Basin (Moore and Nilsen, 1990). Lathrop sandstones have a general northeast-southwest trend and are best developed in Southern San Joaquin County where sandstone thickness approaches $760 \mathrm{~m}$ $(2,500 \mathrm{ft})$. They pinch out to the north, in the vicinity of northern San Joaquin County. Porosities range from 18-27 percent (DOG, 1983). Permeabilities in the sands in the Lathrop Field average $5.9 \times 10^{-14} \mathrm{~m}^{2}$ (60 md; Teitsworth, 1964).

Lathrop sands have produced in only three fields in the southern Sacramento Basin. Before conversion to a gas storage field, the Lathrop Field produced $10.2 \mathrm{Gm}^{3}$ gas (359 BCFG) from a sequence of sandstones almost $600 \mathrm{~m}(2,000 \mathrm{ft})$ thick on a faulted anticline with about $180 \mathrm{~m}$ $(600 \mathrm{ft})$ of closure (Teitsworth, 1964). Reservoir depths range from 2,100-2,600 m (6,900-8,500 $\mathrm{ft})$. Much smaller accumulations have been found in French Camp and Lathrop Southeast fields at depths between $2,110-2,170 \mathrm{~m}(6,925-7,110 \mathrm{ft})$.

Winters sandstones are best developed approximately $30 \mathrm{~km}(20 \mathrm{mi}$.) west-southwest of Sacramento where net sand thickness can exceed $460 \mathrm{~m}$ (1,500 ft; Garcia, 1981). Thick sandstone extends for about $160 \mathrm{~km}$ (100 mi.), paralleling the basin axis, before gradually thinning to the north into Yolo County and pinching out to the south in southern San Joaquin County. Laterally, the sandstones pinch out eastward toward the shelf edge and thicken basinward. Porosities range from a low of 18 percent in deep sands below 2,900 $\mathrm{m}(9,500 \mathrm{ft})$ to a range of 25-38 percent in shallower zones. Permeabilities range from $9.9 \times 10^{-15}$ to $1.7 \times 10^{-12} \mathrm{~m}^{2}$ (10-1,700 md; DOG, 1983). Winters and Lathrop sandstones are overlain by the Sawtooth Shale which provides a regional seal ranging from 100-300 $\mathrm{m}(\sim 300-1,000 \mathrm{ft})$ thick.

Winters sandstones are important gas reservoirs in the southern Sacramento Basin. Producing depths range from $750 \mathrm{~m}(2,450 \mathrm{ft})$ in Dunnigan Hills Field to 2,960 m (9,700 ft) in Union Island Field, where Winters sandstones have produced $7.73 \mathrm{Gm}^{3}$ gas $(273 \mathrm{BCFG})$. Other Winters accumulations include the Bunker $\left(2.6 \mathrm{Gm}^{3}\right.$ gas $\left.(92 \mathrm{BCFG})\right)$, River Island $\left(1.6 \mathrm{Gm}^{3}\right.$ gas (58 BCFG)), Putah Sink (1.3 $\mathrm{Gm}^{3}$ gas (47 BCFG)), Winters (1.2 $\mathrm{Gm}^{3}$ gas (41 BCFG)), and Saxon $\left(0.99 \mathrm{Gm}^{3}\right.$ gas (35 BCFG)) fields. Most significant accumulations involve updip normal fault displacement against impermeable shales.

The main Tracy Formation sands are generally confined to the western edge of the southern Sacramento and northern San Joaquin basins between Suisun Bay and the northwestern corner of Fresno County. Upper Tracy sands cover a smaller area, west of Modesto between Contra Costa County and Merced County (Callaway, 1964). Sandstone thickness varies markedly from less than $15 \mathrm{~m}(50 \mathrm{ft})$ to over $300 \mathrm{~m}(1,000 \mathrm{ft})$ with porosities of 20-28 percent (DOG, 1983). No permeability information was available. Producing sandstone depths range from 1,190 m (3,900 $\mathrm{ft})$ in Tracy Field to over 2,560 m (8,400 ft) in Lathrop Field.

Tracy sandstones are not major reservoirs in the Sacramento Basin but have contributed to the 
cumulative production in the Lathrop $\left(10.2 \mathrm{Gm}^{3}\right.$ gas (359 BCFG)), Tracy $\left(0.48 \mathrm{Gm}^{3}\right.$ gas (17 $\mathrm{BCFG})$ ), and French Camp (0.51 $\mathrm{Gm}^{3}$ gas (18 BCFG)) fields.

Blewett Formation sandstones were deposited contemporaneously with the uppermost Starkey deltaic complexes and are confined to an arcuate trend along the western side of the basin from southern San Joaquin County southward into the northwest corner of Fresno County. Blewett sandstones can range from $\sim 1 \mathrm{~m}$ (a few feet) to $\sim 100 \mathrm{~m}$ (a few hundred feet) thick with aggregate thicknesses up to $300 \mathrm{~m}(1,000 \mathrm{ft})$. Porosity and permeability range from 20-30 percent and $6.9 \times 10^{-14}$ to $5.9 \times 10^{-13} \mathrm{~m}^{2}(70-597 \mathrm{md})$ respectively (DOG, 1983).

Blewett sandstones are only present in the southernmost part of the basin and are not major producers. They have, however, contributed to production in the Vernalis $\left(2.92 \mathrm{Gm}^{3}\right.$ gas (103 BCFG)), McMullen Ranch (1.8 $\mathrm{Gm}^{3}$ gas (64 BCFG)), and Tracy (0.48 $\mathrm{Gm}^{3}$ gas (17 BCFG)) fields.

The undifferentiated Starkey Formation deltaic complexes are more extensive than the marine fans that developed marineward. Starkey sandstones occur throughout the southern Sacramento Basin from southern Colusa and Sutter County where they are truncated by post-Cretaceous angular unconformity, southward into the northern San Joaquin Basin, where they are confined to the eastern half of the basin (Callaway, 1964). Sandstones generally thin westward and are locally absent.

Depths range from about $610 \mathrm{~m}(2,000 \mathrm{ft})$ in southern Sutter County to more than 3,050 m $(10,000 \mathrm{ft})$ in southern Solano and Sacramento counties. Individual sandstones range from $\sim 1 \mathrm{~m}$ (a few feet) to $\sim 100 \mathrm{~m}$ (a few hundred feet) thick with aggregate thicknesses of nearly $460 \mathrm{~m}$ $(1,500 \mathrm{ft})$. Porosities of 14-17 percent are typical for sandstones deeper than 2,900 $\mathrm{m}(9,500 \mathrm{ft})$ and 30-35 percent for shallower sandstones. Permeability data is scare, the only recorded values ranging from $4.9 \times 10^{-14}$ to $9.9 \times 10^{-14} \mathrm{~m}^{2}(50-100 \mathrm{md}$; DOG, 1983). The Starkey Formation is overlain by the H\&T Shale, which provides a regional seal 15 to $100 \mathrm{~m}$ (50 to a few hundred feet) thick.

Starkey sandstones are important gas reservoirs in numerous fields with reservoir depths ranging from $690 \mathrm{~m}$ (2,250 ft) in Catlett Field to 3,137 m (10,288 ft) in Lindsey Slough Field. Reported gas production is frequently commingled with other reservoirs making production estimates unreliable. Starkey sandstones have produced over $1.1 \mathrm{Gm}^{3}$ gas (39 BCFG) in the Sycamore Slough Field and are responsible for a significant portion of the production in the Lindsey Slough (8.75 $\mathrm{Gm}^{3}$ gas (309 BCFG)) and Millar (4.62 $\mathrm{Gm}^{3}$ gas (163 BCFG)) fields.

Throughout part of the southern Sacramento Basin, the H\&T shale is overlain by the upper Cretaceous Mokelumne River Formation. The formation is progressively truncated to the north by the post-Cretaceous angular unconformity until it pinches out in southern Yolo and Sutter counties. In its northern reaches, it contains interbedded sands and shales interpreted to be delta plain, distributary channel, natural levee, and crevasse splay deposits (Johnson, 1990). The interbedded sandstones grade southward into series of thick sands generally designated the as the Second through Fourth Massive Sands which can achieve thicknesses of over $300 \mathrm{~m}(1,000 \mathrm{ft})$ (the Paleocene First Massive Sand is of limited extent). The Massive sands may be locally 
eroded or wholly absent due to Paleocene - Eocene erosion and downcutting by the Martinez and Meganos submarine canyons. Depths range from less than $610 \mathrm{~m}(2,000 \mathrm{ft})$ in southern Sutter County to over 2,745 m (9,000 ft) in southern Contra Costa County. Porosities range from 15-35 percent and permeabilities $2.5 \times 10^{-13}$ to $1.5 \times 10^{-12} \mathrm{~m}^{2}(250-1,500 \mathrm{md}$; DOG, 1983).

Mokelumne River Sandstones are major gas reservoirs. Important Mokelumne sandstone accumulations include the McDonald Island (5.21 Gm $\mathrm{Gm}^{3}$ gas (184 BCFG)) and East Brentwood $\left(1.3 \mathrm{Gm}^{3}\right.$ gas (47 BCFG)) fields. Mokelumne River sandstone pools in the Bunker and River Island fields have produced $2.6 \mathrm{Gm}^{3}$ gas $(91 \mathrm{BCFG})$ and $1.2 \mathrm{Gm}^{3}$ gas (42 BCFG) respectively. Trap types include fault truncations, stratigraphic traps, and unconformity traps sealed by intervening shales up to $30 \mathrm{~m}(100 \mathrm{ft})$ thick and by overlying Martinez and Meganos submarine canyon fill mudstone.

In the southern Sacramento and northern San Joaquin basins, Cretaceous rocks of the Great Valley Sequence are separated from overlying Paleocene and younger beds by a basin-wide unconformity. In the Paleogene, marine and fluvio-deltaic sedimentation resumed in the forearc basin until the emergence of the Stockton Arch in the late Paleogene separated the Sacramento Basin from the San Joaquin Basin.

The most important Paleogene unit in the Sacramento Basin is the Eocene Domengene Formation. It is thought to represent a tide-dominated deltaic system with sediment distribution and geometry complicated by a number of complexities including tectonics and subsidence associated with the Stockton Arch, sediment compaction in the Meganos Gorge, active faulting, and distribution of basin margin uplifts. It includes many facies including channel sands, bars, delta front and shoreline sands, shelf sandstones, and fluvial conglomerate (Cherven, 1983).

Domengine sandstones range from as shallow as $300 \mathrm{~m}(1,000 \mathrm{ft})$ in northern Colusa and Sutter counties to over $1,980 \mathrm{~m}(6,500 \mathrm{ft})$ deep in southern Solano County. Sandstones range from interbedded stringers to beds over $150 \mathrm{~m}(500 \mathrm{ft})$ thick in Contra Costa County. Porosities average 18-32 percent. Permeabilities of $1.5 \times 10^{-14}$ to $6.9 \times 10^{-14} \mathrm{~m}^{2}(15-70 \mathrm{md})$ are reported in the Domengene sandstone in Galt Field.

The Domengine sandstones are prolific gas producers. They are the primary reservoirs in the Rio Vista Field which has produced $99 \mathrm{Gm}^{3}$ gas $(3.5 \mathrm{TCFG})$. It also produces in many other fields but reported production is frequently commingled. Trapping mechanisms include simple fault traps and structural closures through complexly faulted structures and erosional truncation and updip trapping by Markley Submarine Canyon fill. Regionally, the Nortonville Shale overlies the Domengene serving as a seal throughout much of the southern Sacramento and northern San Joaquin basins. Due to a regional unconformity and localized erosion by the Markley Submarine Canyon, its thickness varies widely from a featheredge to upwards of $245 \mathrm{~m}(800 \mathrm{ft})$ in the vicinity of the Kirby Hills Field.

A generalized sandstone isopach map of the Sacramento Basin (Figure 3) reveals good sandstone development paralleling the strike of the basin and ranging from over $300 \mathrm{~m}(1,000 \mathrm{ft})$ in Tehama County to nearly 1,220 m (4,000 ft) in Stanislaus County. The southward thickening is largely the result of the post-Cretaceous regional unconformity, which progressively truncates 
the sand-rich Great Valley Sequence formations to the north, leaving only Forbes and Kione formation sandstones remaining in the northernmost counties.

\subsubsection{San Joaquin Basin}

The San Joaquin Basin comprises the southern half of the Great Valley province. It extends about $350 \mathrm{~km}$ (220 mi.) from the Stockton Arch to its southern terminus at the northern Transverse Ranges, and averages $80-110 \mathrm{~km}$ (50-70 mi.) wide. It is bounded on the east by the Sierra Nevada and on the west by the Central Coast Ranges and the San Andreas Fault.

The basin is filled with predominantly marine Cretaceous and Cenozoic clastic sedimentary rocks that attain an aggregate thickness of over 9,150 $\mathrm{m}(30,000 \mathrm{ft})$ (Figure 2). It also contains the deepest well in the state, which bottomed in Cretaceous siltstone and shale at 7,447 m $(24,426 \mathrm{ft})$ in the Elk Hills Field. 


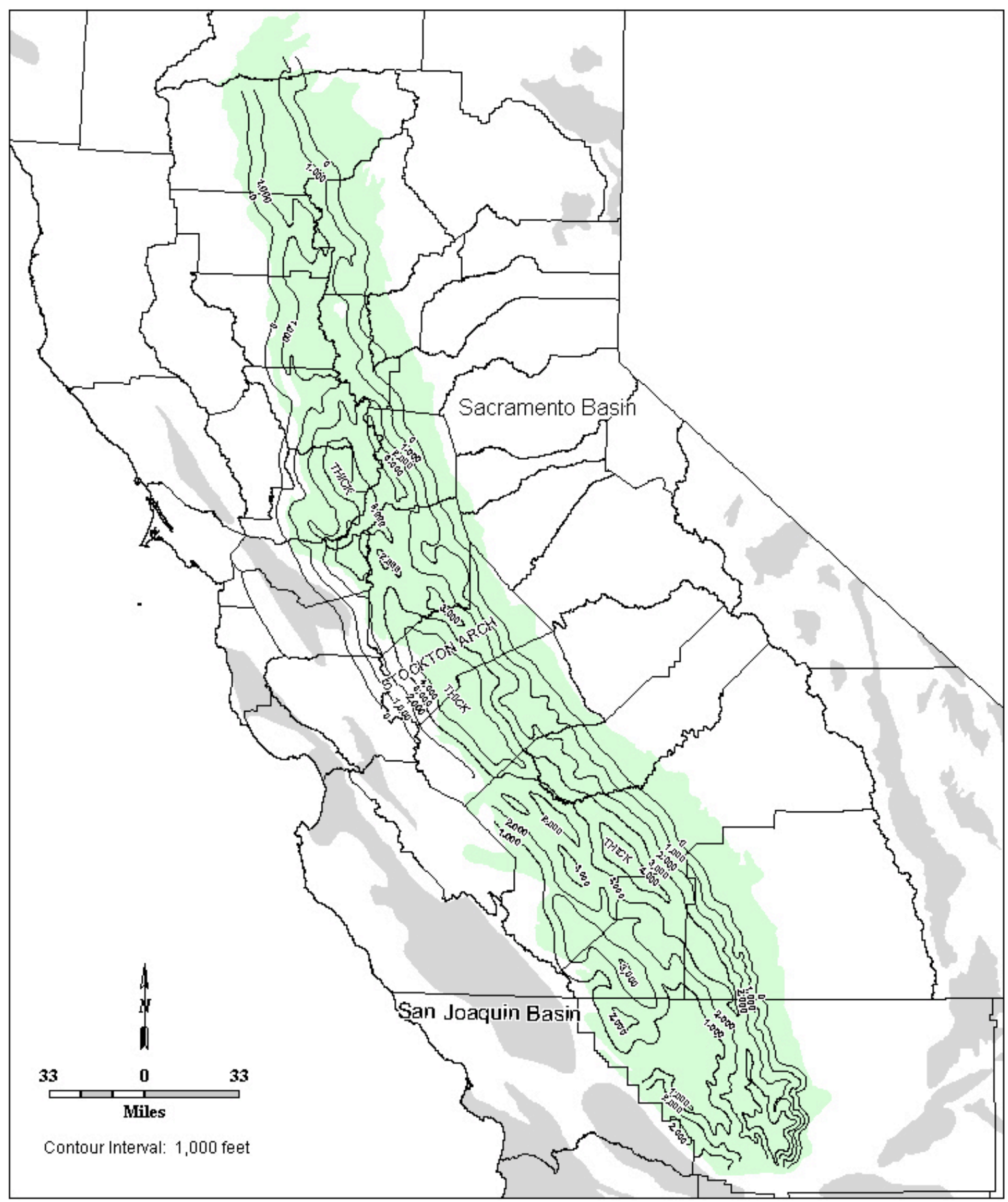

Figure 3. Sacramento and San Joaquin basins - gross sandstone isopach map for depth interval 800-3,050 m (2,625-10,000 ft; or basement). 
During the Mesozoic, the northern San Joaquin and Sacramento basins shared a history of forearc basin sedimentation recorded in the Great Valley Sequence. The Great Valley Sequence thins longitudinally down the axis of the San Joaquin Basin from about 3,050 m (10,000 ft) or more near the Stockton Arch to its pinch out against the north flank of the Bakersfield Arch. Tertiary sedimentation in the San Joaquin Basin records the change from a forearc basin to a wrench related strike-slip basin with multiple sediment sources. Depositional systems filled the basin from sources to the west and south, while prograding shelf deposition continued to infill the basin from the north and east (Callaway, 1990). A thick and complex Neogene marine basin developed in the southern San Joaquin Valley in response to right lateral transform motion along the San Andreas Fault system (Bartow and Nilsen, 1990). This basin received a thick sequence of dominantly marine Miocene and Pliocene aged sediment from which most of the basin's oil is produced. Consequently, the San Joaquin Basin contains many more clastic sequences with geologic carbon sequestration potential than any other California basin.

Only in the northern part of the basin are Cretaceous Great Valley Sequence rocks encountered at reasonable depths. Thick upper Cretaceous sandstones of the Panoche and younger formations produce in several small gas fields in Merced, Madera, and Fresno Counties, which for practical purposes can be considered extensions of the Sacramento Basin and are not reconsidered here.

Important early Tertiary sandstones include the Eocene Gatchell sandstone of the Lodo Formation, and sandstones within the Kreyenhagen Formation. These units are some of the principal stratigraphic and structural reservoirs in the belt of fold-related oil fields along the west side of the basin. Unlike the Sacramento Basin, Domengene sandstones are not well developed in the San Joaquin Basin.

The Gatchell sandstones are confined to the north, northeastern, and western parts of the San Joaquin Basin and pinch out to the east and south. Sandstones are generally $\sim 10 \mathrm{~m}$ (a few tens of $\mathrm{ft}$ ) to $\sim 100 \mathrm{~m}$ (hundreds of feet) thick. Depths range from a $\sim 1,000 \mathrm{~m}$ (few thousand feet) on the west to over 3,660 m (12,000 ft) in the vicinity of Kettleman North Dome Field in western Kings County. Porosity and permeability in sandstones between 1,980-2,290 m (6,500-7,500 ft) deep in Coalinga East Extension Field average 20 percent and $4.2 \times 10^{-13} \mathrm{~m}^{2}(421 \mathrm{md})$, and decline to 14-16 percent and $6.4 \times 10^{-14}$ to $7.4 \times 10^{-14} \mathrm{~m}^{2}(65-75 \mathrm{md})$ at depths between $2,805-3,570 \mathrm{~m}$ (9,200 and 11,700 ft) deep. Kreyenhagen Formation shales, which can exceed $365 \mathrm{~m}$ (1,200 ft) thick in the Coalinga East Extension Field, form the overlying seal.

The Gatchell sandstone is the primary reservoir in Coalinga East Extension Field where it has produced more than 80.1 million cubic meters $\left(\mathrm{Mm}^{3}\right)$ oil $(504 \mathrm{MMBO}$, or million barrels of oil) and 15.4 billion cubic meters $\left(\mathrm{Gm}^{3}\right)$ gas $(542 \mathrm{BCFG})$ from an updip pinch out of the Gatchell sandstone between 1,980-2,290 m (6,500-7,500 ft) deep. Gatchell sandstones have also produced $1.6 \mathrm{Mm}^{3}$ oil (10 MMBO) and $0.40 \mathrm{Gm}^{3}$ gas (14 BCFG) from stratigraphic traps at $3,050 \mathrm{~m}(10,000 \mathrm{ft})$ in the Guijarral Hills Field. Equivalent Lodo Formation sandstones have produced more than $3.8 \mathrm{Mm}^{3}$ oil $(24 \mathrm{MMBO})$ and $30.78 \mathrm{Gm}^{3}$ gas $(1,087 \mathrm{BCFG})$ from structural and stratigraphic traps at 3,050-3,660 m (10,000-12,000 ft) in the Kettleman North Dome Field.

The Eocene Kreyenhagen Formation is continuous throughout much of the basin. In the north it is dominantly marine shale, but thickens south and eastward and interfingers with the Point of 
Rocks Sandstone member. The Point of Rocks sandstone is a thick wedge-shaped submarine fan complex that reaches almost 1,525 $\mathrm{m}(5,000 \mathrm{ft})$ thick in the vicinity of the Antelope Hills Field and covers much of the southern basin. On the western side of the basin, the Point of Rocks sandstones occur at shallow to moderate depths of 457-1,525 m (1,500-5,000 ft), but deepens dramatically eastward toward the basin center where the Kreyenhagen was encountered at 5,335 m (17,500 ft) in the Coles Levee North Field southwest of Bakersfield.

At shallow to moderate depths, Point of Rocks sandstones exhibit porosities in the range of 2038 percent and permeabilities of $3.9 \times 10^{-14}$ to $4.9 \times 10^{-12} \mathrm{~m}^{2}$ (40 to $4,950 \mathrm{md}$ ). Porosity and permeability decline with depth to 12 percent and $9.9 \times 10^{-15} \mathrm{~m}^{2}(10 \mathrm{md})$ at 5,335 $\mathrm{m}(17,500 \mathrm{ft})$ deep in Coles Levee North Field (DOGGR, 1998). Where present, upper Kreyenhagen shales can provide seals up to $>100 \mathrm{~m}$ (several hundred feet) thick. In parts of the basin where the upper shales have been truncated, Point of Rocks sandstone may be unconformably overlain by $>100 \mathrm{~m}$ (several hundred feet) Oligocene Cymric or Santos shale.

Point of Rocks sandstones produce at shallow to moderate depths at several fields along the southwest margin of the basin. In the Pyramid Hills Field, the Point of Rocks and the lower Kreyenhagen Canoas sandstones have produced more than $4.8 \mathrm{Mm}^{3}$ oil (30 MMBO) and 12.3 $\mathrm{Mm}^{3}$ (433 MMCF) gas from structural and stratigraphic traps at depths of 200-1,495 m (650$4,900 \mathrm{ft}$ ). Point of Rocks sandstones have also produced varying amounts from structural traps on faulted anticlines at depths between 183-1,860 m (600-6,100 ft) in the Devil's Den, Belgian Anticline, and Cymric fields. Production data for these fields is commingled.

Oligocene-lower Miocene Vedder sandstones and their equivalents are widespread throughout the south and southeastern part of the basin but are generally absent elsewhere. Vedder sandstones are transgressive marine slope, shelf, and deltaic sands that grade eastward into equivalent nonmarine fanglomerates of the Walker Formation. Sandstones range in thickness from $9 \mathrm{~m}$ (30 ft) to $>100 \mathrm{~m}$ (several hundred feet), but in Tejon North Field multiple Vedder sands comprise an interval more than $610 \mathrm{~m}(2,000 \mathrm{ft})$ thick. At moderate depths of 1,525-2,745 $\mathrm{m}(5,000-9,000 \mathrm{ft})$, porosities range from $20-40$ percent and permeabilities $3.1 \times 10^{-14}$ to $2.4 \times 10^{-12}$ $\mathrm{m}^{2}$ (31-2,400 md), declining to about 12 percent and $1.5 \times 10^{-14} \mathrm{~m}^{2}(15 \mathrm{md})$ at 5,370 $\mathrm{m}(17,600 \mathrm{ft})$ in the Semitropic Field (DOGGR, 1998). Vedder sandstones are overlain by siltstone and shale

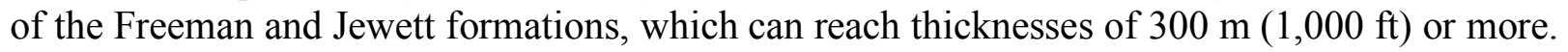

Vedder sandstones (and Walker Formation equivalents) have produced oil in many fields, primarily in the Bakersfield Arch area and farther south. Producing depths range from as shallow as $430 \mathrm{~m}(1,400 \mathrm{ft})$ in the Mount Poso and Round Mountain fields along the eastern basin shelf to as deep as 5,370 $\mathrm{m}(17,600 \mathrm{ft})$ in the Semitropic field near the basin center. Production volumes are difficult to ascertain since production records are commingled, but Vedder sandstones are known to have produced $3.3 \mathrm{Mm}^{3}$ oil (21 MMBO) and $5.92 \mathrm{Gm}^{3}$ gas (209 BCFG) in Tejon North Field. Trapping mechanisms include faulted anticlines, updip pinch outs, and permeability barriers.

In the southeastern basin, Vedder sandstones are overlain by the lower Miocene Jewett and Pyramid Hills sandstones and the Freeman silt. The Freeman silt gradationally overlies and intertongues with the Jewett sandstone and the overlying lower Miocene Olcese Sandstone 
(Bartow and McDougall, 1984). The Jewett and Pyramid Hills sandstones are not particularly thick, generally averaging between 3 and $30 \mathrm{~m}$ (10 and $100 \mathrm{ft})$. Producing depths range from 380-490 m (1,250-1,600 ft) in Round Mountain Field to 3,215 m (10,550 ft) in Rio Bravo Field. Porosities between 15-22 percent are typical in sandstones below 3,050 m (10,000 ft) while higher porosities of up to 38 percent occur in shallow sands. Permeabilities range from $5.9 \times 10^{-15}$ to $4.9 \times 10^{-12} \mathrm{~m}^{2}(6-5,000 \mathrm{md}$; DOGGR, 1998).

The Jewett and Pyramid Hill sandstones are important oil reservoirs in the southeast San Joaquin Basin. Traps included stratigraphic and permeability pinchouts, faults, and anticlinal closures. In most cases sandstones are encased in or overlain by Freeman and Jewett siltstone and shale $>100$ $\mathrm{m}$ (several hundred feet) thick. Much production is commingled, but in the Round Mountain Field, Jewett and Pyramid Hill sandstones have produced $14 \mathrm{Mm}^{3}$ oil (89 MMBO) and $45 \mathrm{Mm}^{3}$ (1.6 BCFG) from between 365-580 m (1,200-1,900 ft). In the Greeley Field, Jewett and Vedder sandstones produced $16 \mathrm{Mm}^{3}$ oil (98 MMBO) and $0.71 \mathrm{Gm}^{3}$ gas (25 BCFG) from $3,445 \mathrm{~m}$ $(11,300 \mathrm{ft})$.

The overlying Olcese Sandstone is also confined to the southeastern portion of the basin where the sands were deposited in a marine environment along the basin margin. The unit is dominantly sandstone and reaches a thickness of about $360 \mathrm{~m}(1,180 \mathrm{ft})$ near the Round Mountain Field (Bartow and McDougall, 1984). The Olcese grades basinward into the upper Freeman Silt and the overlying Round Mountain Shale which provides a seal roughly 30-90 m (100-300 ft) thick. Olcese sands range in depth from $700 \mathrm{~m}(2,300 \mathrm{ft})$ in the Ant Hill Field to 2,715 $\mathrm{m}(8,900 \mathrm{ft})$ in the Mountain View Field. Porosities range from 20-34 percent and permeabilities from $1.5 \times 10^{-13}$ to $2.0 \times 10^{-12} \mathrm{~m}^{2}(150-2,000 \mathrm{md}$; DOGGR, 1998).

Most reported production is commingled with other reservoirs. However, Olcese sands are reported to have produced more than $0.8 \mathrm{Mm}^{3}$ oil $(5 \mathrm{MMBO})$ and $0.37 \mathrm{Gm}^{3}$ gas (13 $\mathrm{BCFG)} \mathrm{from}$ two zones in the Wheeler Ridge Field.

The lower-middle Miocene marine Temblor Formation was deposited on the western basin margin, originating from uplifts associated with initiation of transform motion along the San Andreas Fault zone. It grades eastward into the nonmarine Zilch Formation. The Temblor Formation includes several important sandstones, including the Carneros, Wygal, Phacoides, and Agua sandstones. Sandstones tend to be of multiple environments including estuarine, and shoreline environments to the west and deeper marine turbidite environments farther east and southeast. Individual sandstones are frequently lenticular and discontinuous.

The most widespread is the Carneros sandstone, a large turbidite fan that spread eastward into the central basin. It is well developed in the vicinity of the Elk Hills, Asphalto, Railroad Gap and Northeast McKittrick fields. The Carneros interval correlates to the upper facies of the FreemanJewett interval and the Olcese Sand zone along the eastern basin margin.

Most Temblor sandstones range from $>1 \mathrm{~m}$ (a few feet) to $91 \mathrm{~m}(300 \mathrm{ft})$ thick. Locally, aggregate sandstone thickness can approach $150 \mathrm{~m}$ (500 ft) (Jalicitos Field) to $305 \mathrm{~m}(1,000 \mathrm{ft})$ (Tulare Lake Field). Porosities in shallow to intermediate depth sandstones range from 10-40 percent while permeabilities vary from $6.9 \times 10^{-15}$ to $9.9 \times 10^{-12} \mathrm{~m}^{2}$ (7 to $10,000 \mathrm{md}$ ). Sandstones greater 
than 3,050 $\mathrm{m}(10,000 \mathrm{ft})$ deep exhibit porosities of 12-21 percent and permeabilities of 5.9x $10^{-14}$ to $4.9 \times 10^{-13} \mathrm{~m}^{2}$ (60 to $500 \mathrm{md}$; DOGGR, 1998).

Intraformational shales provide seals for the Temblor sandstones. The Santos Shale, which can range up to $150 \mathrm{~m}(500 \mathrm{ft})$ thick, overlies the lowermost Wygal and Phacoides sandstones. The Upper Santos shale overlies the Agua sand and ranges up to $>100 \mathrm{~m}$ (several hundred $\mathrm{ft}$ ) thick. The Media Shale is 60-90 m (200-300 ft) thick and overlies the Carneros Sandstone.

Temblor sandstones are important reservoirs in the San Joaquin Basin and produce throughout much of the western basin from the Coalinga Field in Fresno County southeastward to the Asphalto and Midway Sunset fields in southwestern Kern County. Trapping mechanisms include low relief structural closures, faulted anticlines, updip pinch outs, and permeability barriers. Production has been established from as shallow as $60 \mathrm{~m}(200 \mathrm{ft})$ in the Devil's Den Field to 4,210 m (13,800 ft) in Tulare Lake Field. In the Coalinga Field, Temblor sandstones have produced over $140 \mathrm{Mm}^{3}$ oil (881 MMBO) and $6.37 \mathrm{Gm}^{3}$ gas (225 BCFG) from sandstones between 215 and 1,400 m (700 and 4,600 ft) deep. Other important Temblor fields include the Kettleman North Dome and Belridge fields where Temblor sandstones have produced more than $68.8 \mathrm{Mm}^{3}$ oil (433 MMBO) and $52.50 \mathrm{Gm}^{3}$ gas (1,854 BCFG), and $10 \mathrm{Mm}^{3}$ oil (65 MMBO) and $16.1 \mathrm{Gm}^{3}$ gas (569 BCFG), respectively, from depths of 1,830-2,685 m (6,000-8,800 ft).

Nonmarine Zilch sandstones tend to be relatively thin, ranging between 2-30 m (5-100 ft) thick, within an otherwise thick section of interbedded sands, siltstones, and mudstones. Where they produce, they are usually structurally and stratigraphically controlled and range in depth from $825 \mathrm{~m}$ (2,700 ft) (Chowchilla Field) to 2,075 m (6,800 ft) (Riverdale Field). Despite the absence of thick individual sandstones, they have produced over $10 \mathrm{Mm}^{3}$ oil $(64 \mathrm{MMBO})$ and $1.7 \mathrm{Gm}^{3}$ gas (59 BCFG) in the Raisin City, Helm, and Riverdale fields. Porosities range from 24-35 percent and permeabilities from $4.9 \times 10^{-15}$ to $7.6 \times 10^{-13} \mathrm{~m}^{2}$ (5 to $771 \mathrm{md}$; DOGGR, 1998).

During the Upper Miocene, the southern San Joaquin Basin underwent rapid structural changes. Localized uplifts shed sands into the subsiding basin in the form of deep marine turbidite channel and lobe systems which interfingered with deep water, organic rich, porcelanites and siliceous shales of the Monterey Formation and the laterally equivalent Fruitvale Formation on the east side of the basin. While local names are common, Monterey and Fruitvale formation sandstones are collectively called Stevens sandstones. The primary source for the Stevens sandstones was the Gabilan uplift, west of the San Andreas Fault. At the same time, along the eastern basin margin, sediments eroded from the Sierra Nevada were being deposited as submarine fan deposits of the Santa Margarita Formation and nonmarine deposits of the Chanac Formation.

Stevens sandstones are generally medium-fine grained arkosic sands between 2-76 m (5-250 ft) thick. However, thick sections of interbedded sandstone and shale can exceed 5,000 ft) in aggregate thickness. Depths range from less than $60 \mathrm{~m}(200 \mathrm{ft})$ on the west side of the basin to over 4,270 $\mathrm{m}(14,000 \mathrm{ft})$ in the south central basin. Porosities in sandstones shallower than 3,050 $\mathrm{m}(10,000 \mathrm{ft})$ range from $20-35$ percent with permeabilities of up to $6.4 \times 10^{-12} \mathrm{~m}^{2}(6,500 \mathrm{md})$ in the shallowest sandstones. Below 3,050 $\mathrm{m}(10,000 \mathrm{ft})$, porosity and permeability decline to 10 20 percent and $2.0 \times 10^{-16}$ to $9.9 \times 10^{-13} \mathrm{~m}^{2}(0.2$ to $1,000 \mathrm{md}$; DOGGR, 1998). Trapping mechanisms include updip pinch outs, structural drape over anticlinal highs, and differential 
compaction closures. Enclosing Monterey or Fruitvale shales provide the seals.

Stevens sandstones are some of the most important reservoirs in the basin. In Midway-Sunset Field, the nation's fourth largest oil field, they have produced more than $430 \mathrm{Mm}^{3}$ oil $(2.7 \mathrm{BBO}$, or billions of barrels) and $16.1 \mathrm{Gm}^{3}$ gas (567 BCFG). Other fields with significant Stevens production include Elk Hills (110 $\mathrm{Mm}^{3}$ oil (691 MMBO) and $37 \mathrm{Gm}^{3}$ gas (1.3 TCFG)), Coles Levee North (26.1 $\mathrm{Mm}^{3}$ oil (164 MMBO) and $6.99 \mathrm{Gm}^{3}$ gas $\left.(247 \mathrm{BCFG})\right)$, Yowlumne (17.0 $\mathrm{Mm}^{3}$ oil (107 MMBO) and $2.7 \mathrm{Gm}^{3}$ gas (94 BCFG)), Buena Vista (14 $\mathrm{Mm}^{3}$ oil (91 MMBO) and $7.31 \mathrm{Gm}^{3}$ gas (258 BCFG)), Paloma (9.7 $\mathrm{Mm}^{3}$ oil (61 MMBO) and $12.2 \mathrm{Gm}^{3}$ gas (432 BCFG)), and Coles Levee South (9.4 $\mathrm{Mm}^{3}$ oil (59 MMBO) and $12.8 \mathrm{Gm}^{3}$ gas (452 BCFG)).

Along the southeastern side of the basin, the Chanac Formation overlies the Santa Margarita Formation in a regressive relationship. Westerly flowing fluvio-deltaic complexes of the Chanac Formation prograded over the Santa Margarita Formation shelf and submarine fan deposits. Chanac sandstones are generally limited to the shallower parts of the eastern basin, but the Santa Margarita marine facies extend farther basinward to greater depths. While individual sandstones may be only $\sim 1 \mathrm{~m}$ (a few feet) thick, aggregate sandstone in both the Chanac and Santa Margarita formations can reach over $150 \mathrm{~m}(500 \mathrm{ft})$ thick. Porosities in known reservoirs range from $20-40$ percent and permeabilities from $9.9 \times 10^{-16}$ to $9.9 \times 10^{-12} \mathrm{~m}^{2}$ ( 1 to $10,000 \mathrm{md}$; DOGGR, 1998).

Chanac and Santa Margarita sandstones have produced considerable oil from reservoirs between $150 \mathrm{~m}(500 \mathrm{ft})$ and 2,470 $\mathrm{m}(8,100 \mathrm{ft})$ deep. Stratigraphic and fault traps are common. In most cases, reported production is commingled with that of other reservoirs. However, Chanac sandstones have produced nearly $31.8 \mathrm{Mm}^{3}$ oil $(200 \mathrm{MMBO})$ and $0.82 \mathrm{Gm}^{3}$ gas $(29 \mathrm{BCFG})$ in the Kern Front Field from an average depth of $700 \mathrm{~m}(2,290 \mathrm{ft})$. Santa Margarita sandstones have produced 2.1 $\mathrm{Mm}^{3}$ oil (13 MMBO) and $800 \mathrm{Mm}^{3}$ (1 BCFG), from a shallow faulted anticline in the Wheeler Ridge Field.

The Pliocene Etchegoin Formation overlies the Chanac and Santa Margarita Formations on the east side of the basin and the Monterey and Fruitvale formations in the deeper basin. The San Joaquin Formation, in turn, overlies the Etchegoin Formation. These formations represent the transition from deep marine to nearshore and brackish water environments. The transition to nonmarine conditions was completed in the Pleistocene with the deposition of the Tulare Formation.

The Etchegoin Formation consists largely of sands and mudstones deposited in transitional deltaic, bay, estuary, and shoreface environments throughout much of the west and central basin where it reaches a thickness of about 1,680 m (5,500 ft). Etchegoin sands are poorly indurated andesitic arkoses derived from the Sierran magmatic arc and Franciscan Coast Range sources (Loomis, 1990). Individual sandstones are generally thin, ranging from 2 to over $60 \mathrm{~m}$ (5 to over $100 \mathrm{ft}$ ) but total sandstone thickness is considerably more. Sandstones are enclosed in, or overlain by, Etchegoin shales ranging from $>1 \mathrm{~m}$ (a few feet) to over $300 \mathrm{~m}(1,000 \mathrm{ft})$ thick. Porosities range from 12-40 percent and permeabilities from $9.9 \times 10^{-16}$ to $2.2 \times 10^{-11} \mathrm{~m}^{2}$ (1 to $22,320 \mathrm{md})$ in sandstones up to $2,290 \mathrm{~m}(7,500 \mathrm{ft})$ deep, and decline to 17 percent and $2.0 \times 10^{-13}$ $\mathrm{m}^{2}(200 \mathrm{md})$ at $3,170 \mathrm{~m}(10,400 \mathrm{ft})$ in the Yowlumne Field (DOGGR, 1998). 
Etchegoin sandstones are important reservoirs and have produced oil from as shallow as $150 \mathrm{~m}$ $(500 \mathrm{ft})$ in the Coalinga Field to as deep as 3,170 $\mathrm{m}(10,400 \mathrm{ft})$ in the Yowlumne Field at the south end of the basin. Most production is commingled, but Etchegoin sandstones have produced more than $124 \mathrm{Mm}^{3}$ oil (782 MMBO) and $20.4 \mathrm{Gm}^{3}$ gas (719 BCFG) from between 700-1,280 $\mathrm{m}(2,300-4,200 \mathrm{ft})$ in the Buena Vista Field. Trap types include stratigraphic pinch outs, subunconformity traps, faults and simple anticlinal closures.

The San Joaquin Formation reaches a maximum thickness of approximately $680 \mathrm{~m}(2,232 \mathrm{ft})$ and is composed largely of brackish water sandstone and mudstone derived from the Sierran arc, the Coast Ranges, and the Gabilan Range. The formation is generally shallow ranging from about $150 \mathrm{~m}(500 \mathrm{ft})$ in the Midway-Sunset Field on the west side of the basin to 1,400 m (4,600 ft) in the Bowerbank Field nearer the basin center. Sandstones tend to be thin and discontinuous ranging from $>1 \mathrm{~m}$ (a few feet) to $15 \mathrm{~m}(50 \mathrm{ft})$ thick and encased in mudstone and shale. Porosity and permeability in the shallow sands range between 28 to 34 percent, and $1.3 \times 10^{-13} \mathrm{~m}^{2}(135 \mathrm{md})$ respectively (DOGGR, 1998).

Sandstones in the San Joaquin Formation have produced oil and gas primarily from thin sands on anticlinal closures or flanking stratigraphic pinch outs. Fault truncations are also common. Reported production is usually commingled, but in the Trico Gas Field thin sandstones between $770-983 \mathrm{~m}(2,525-3,225 \mathrm{ft})$ deep have produced 5.69 $\mathrm{Gm}^{3}$ gas (201 BCFG) on a shallow structural closure.

The Plio-Pleistocene Kern River and Pleistocene Tulare formation are the youngest and shallowest units in the basin. They consist of a poorly consolidated terrestrial progradational deposits of conglomerate, alluvial and fluvial sand, silt, and clay, overlain by Holocene alluvium. Sandstones are thin and discontinuous. The Tulare Formation sediments were shed by uplifts to the west, while the Kern River Formation sediments were shed from the Sierra Nevada on the east. The Kern River Formation is not widespread and interfingers basinward with beds of the Etchegoin, San Joaquin, and Tulare formations.

While the Tulare and Kern River formations are important oil reservoirs, having produced over $320 \mathrm{Mm}^{3}$ oil (2.0 BBO), they are too shallow for $\mathrm{CO}_{2}$ sequestration throughout most of their range. Tulare and upper Kern River beds generally range from 61-610 m (200-2,000 ft) deep

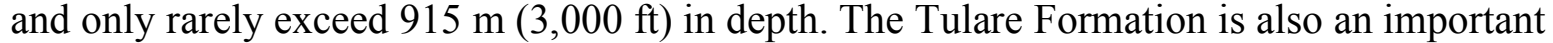
aquifer in much of the San Joaquin Valley. Only near the basin axis, where they interfinger with the Etchegoin and Santa Margarita formations, do beds of the lower Kern River Formation reach depths of about 2,134 m (7,000 ft). Shallow producing Kern River sandstones above $455 \mathrm{~m}$ $(1,500 \mathrm{ft})$ exhibit porosities of $30-40$ percent and permeabilities of $9.9 \times 10^{-13}$ to $4.9 \times 10^{-12} \mathrm{~m}^{2}$ (1,000 to 5,000 md). Sandstones at 1,494 m (4,900 ft) deep, in the Mountain View Field, average 25 percent and $1.5 \times 10^{-14}$ to $7.9 \times 10^{-14} \mathrm{~m}^{2}$ (15 to $\left.80 \mathrm{md}\right)$.

A gross sandstone isopach map (Figure 3) shows that sandstone occurs in a trend thickening to over 1,220 m (4,000 ft) parallel to the basin axis. Unlike the Sacramento Basin, the isopach interval includes largely Eocene Gatchell Formation through Pliocene San Joaquin Formation sandstones deposited above the post-Cretaceous unconformity. However, some upper Cretaceous 
Great Valley Sequence sandstones contribute to the isopach in the northern basin, while lower beds of the Kern River and Tulare formations are included in deeper portion of the southern basin.

\subsubsection{Transverse Ranges Province}

The Transverse Ranges are an east-west trending series of mountain ranges and valleys extending about $520 \mathrm{~km}$ (320 mi.) from Point Arguello eastward to the Mojave Desert. The largest and most important sedimentary basin is the Ventura Basin, a complexly folded and faulted, Cenozoic marine sedimentary basin. The western two thirds of the basin extends offshore to include the Santa Barbara Channel between the Channel Islands and Santa Ynez Mountains. The onshore portion comprises about 4,080 $\mathrm{km}^{2}$ (1,575 sq. mi.) including the Santa Clara Valley and Oxnard Plain. The onshore basin is bounded by the Santa Ynez and Santa Monica mountains to the north and south respectively, and the San Gabriel Fault to the east.

\subsubsection{Ventura Basin}

The Ventura Basin is the deepest of California's Cenozoic basins, containing more than 17,680 $\mathrm{m}(58,000 \mathrm{ft})$ of largely marine sediments (Figure 4). Consequently, the basin includes numerous upper Cretaceous through Pleistocene age sandstones with sequestration potential, and possibly enhanced oil recovery opportunities.

Along the east and northeast margins, basement rocks consist of granodiorite and related plutonic rocks intruded into older gneisses and schists. Along the south rim of the basin, and in outcrops in the Santa Monica Mountains, basement is phyllite and schist intruded by diorite and granodiorite. Franciscan sandstone, shale and chert, intruded by mafic and ultramafic rocks form the basement in the north and northwestern part of the basin.

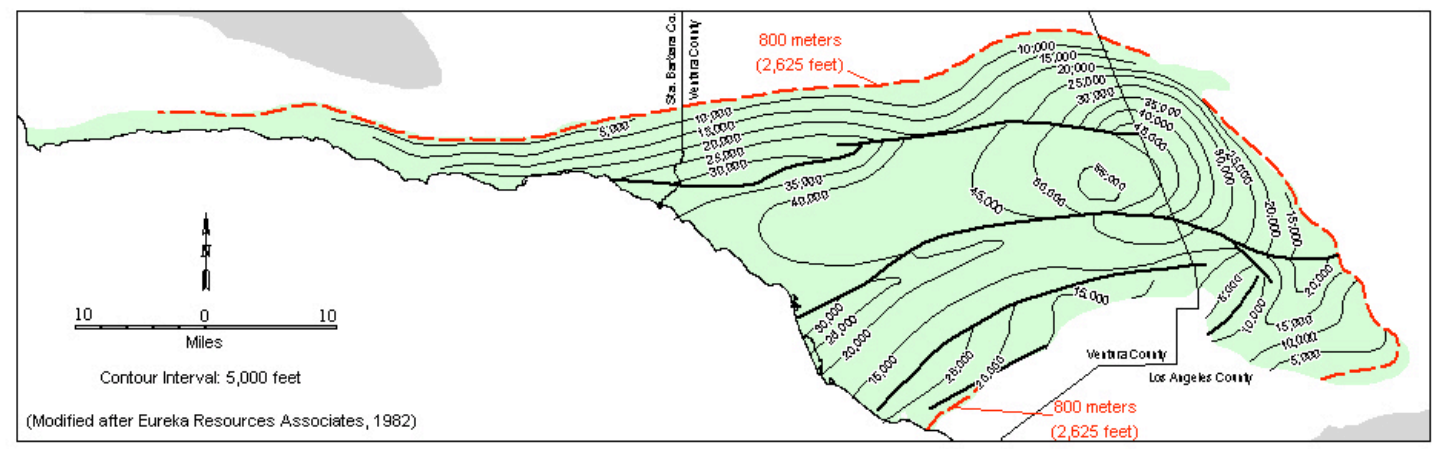

Figure 4. Ventura Basin - depth-to-basement map.

During the late Cretaceous and early Tertiary, sedimentation was in a forearc basin. By the early Miocene, subduction was replaced by crustal stretching, which began the formation of the Ventura and nearby Los Angeles and San Joaquin basins, and allowed the accumulation of thick sections of Miocene sediment. Near the close of the Miocene, accelerated deepening provided

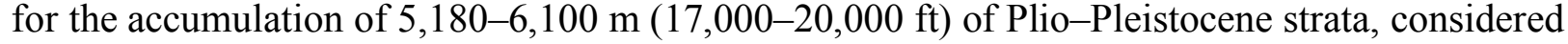


to be the world's thickest Plio-Pleistocene section (Bailey, 1954). About mid-Pleistocene, basin filling ceased and the main Coast Range orogeny occurred. During this time, the basin's structural complexity evolved and most of the intrabasin anticlines, folds and faults formed including the large Oak Ridge, Simi, and Santa Ynez reverse faults with displacements of 1,525$4,575 \mathrm{~m}(5,000-15,000 \mathrm{ft})$ or more (Bailey, 1954). The basin is characterized by major east-west trending thrust faults and tightly folded anticlinal trends that contain the majority of the basin's oil reserves.

Cretaceous rocks are poorly understood in the subsurface due to their extreme depth. However, from 915-2,440 m (3,000-8,000 ft) of Cretaceous marine sandstone, conglomerate, and shale are thought to rest on basement. Two oil fields, now abandoned (Horse Meadows and Mission fields), have yielded commercial hydrocarbons from structural and stratigraphic traps in Cretaceous sandstones of the Tuna Canyon and Chico formations at moderate depths of 1,265$2,195 \mathrm{~m}(4,150-7,200 \mathrm{ft})$. Porosity and permeability data is not readily available.

Cretaceous rocks are overlain by the lower Eocene Santa Susana Formation and the middle Eocene Llajas and Juncal formations. Sandstones in these formations are not known to be significant hydrocarbon reservoirs, producing only minor amounts of oil and gas from depths of 250-1,980 $\mathrm{m}(825-6,500 \mathrm{ft})$. Limited data indicates that these sands have porosities in the range of 22-35 percent and permeability of about $1.5 \times 10^{-13} \mathrm{~m}^{2}$ (150 md; DOGGR, 1991).

The late Eocene-early Miocene nonmarine Sespe Formation is widespread and consists of up to 2,135 m (7,000 ft) of interbedded sandstones, siltstones, and mudstones deposited in braided stream, meandering river, and fan delta environments. Individual sandstones tend to be thin and lenticular ranging between $>1 \mathrm{~m}$ (a few feet) to $>10 \mathrm{~m}$ (several tens of feet) thick, but may reach up to $61 \mathrm{~m}(200 \mathrm{ft})$ thick. Aggregate reservoir thicknesses range between 15-915 m (50-3,000 $\mathrm{ft}$ ). Due to the intense folding and faulting, producing depths vary markedly from as shallow as $30 \mathrm{~m}(100 \mathrm{ft})$ to over 3,355 (11,000 ft), but non-producing sandstones may be present to depths greater than 6,100-7,620 m (20,000-25,000 ft) in deeper portions of the Santa Clara Trough (Keller, 1995). Porosities in shallow sandstones above $1,830 \mathrm{~m}(6,000 \mathrm{ft})$ range from 18-35 percent with reported permeabilities between $2.4 \times 10^{-14}$ and $3.0 \times 10^{-13} \mathrm{~m}^{2}$ (24 and $\left.300 \mathrm{md}\right)$. Sandstones between 1,830-3,355 m (6,000-11,000 ft) exhibit lower porosities and permeabilities of 15 to 28 percent and $3.9 \times 10^{-15}$ to $2.4 \times 10^{-13} \mathrm{~m}^{2}$ (4 to $243 \mathrm{md}$; DOGGR, 1991).

The combined Sespe and Oxnard fields have produced over $11 \mathrm{Mm}^{3}$ oil (72 MMBO) and 2.4 $\mathrm{Gm}^{3}$ gas $(84 \mathrm{BCFG})$, largely from Sespe sandstones. Numerous smaller fields have produced between 0.8 and $1.6 \mathrm{Mm}^{3}$ oil (5 and $10 \mathrm{MMBO}$ ). Generally, traps are anticlinal closures or stratigraphic pinch outs with interbedded siltstones and mudstones providing the seals.

The top of the Sespe formation varies from conformable to strongly unconformable. Where present, shallow marine sandstones of the lower Miocene Vaqueros Formation rest conformably on the Sespe Formation. While individual sandstones can be $>1 \mathrm{~m}$ (a few feet) up to about $91 \mathrm{~m}$

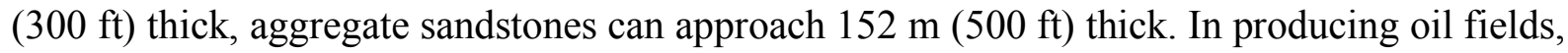
Vaqueros sandstones range from 335-1,205 $\mathrm{m}$ (1,100 to 3,950 ft) deep with porosities between 21 and 30 percent. Permeability of $9.9 \times 10^{-14} \mathrm{~m}^{2}(100 \mathrm{md})$ is reported in several sandstones (DOGGR, 1991). In the deeper basin, depths are similar to those of the Sespe Formation. 
Vaqueros sandstones produce in about ten shallow oil and gas fields. Oil production is commingled in most cases, but sandstones in the La Goleta Gas Field have produced $1.3 \mathrm{Gm}^{3}$ gas (47 BCFG). Fault traps, complexly faulted structures, simple anticlinal closures, and stratigraphic pinchouts all contribute to trapping. Vaqueros sandstones are overlain by the Rincon shale which provides a regional seal between 152-1,525 $\mathrm{m}(500-5,000 \mathrm{ft})$ thick for the Vaqueros and older formations.

Upper Miocene through Pleistocene rocks are some of the most important reservoirs in the Ventura Basin and are represented by oil and gas accumulations in structural and combination traps in sandstone reservoirs. Known traps are largely anticlinal with associated faulting. Stratigraphic traps are rare (Keller, 1995).

The marine upper Miocene Modelo Formation was deposited in the northern part of the Ventura basin at bathyal depths. The Modelo Formation is equivalent in part to the Monterey Formation in the San Joaquin and Los Angeles basins. In the subsurface it reaches a maximum thickness of $3,050 \mathrm{~m}(10,000 \mathrm{ft})$, but is absent east of Newhall and Saugus. Producing depths range from about $152 \mathrm{~m}(500 \mathrm{ft})$ in the Piru Field to over 4,330 m (14,200 ft) in the Newhall-Potrero Field, but unproductive sandstones extend to greater depth. The deepest well in the basin bottomed in the upper Miocene section at 6,555 m (21,500 ft) (Keller, 1995).

Modelo sandstones range from $>10 \mathrm{~m}$ (a few tens of feet) to over $152 \mathrm{~m}(500 \mathrm{ft})$ thick. In sandstones up to $1,830 \mathrm{~m}(6,000 \mathrm{ft})$ deep, porosity ranges from 20-30 percent and permeability from $1.6 \times 10^{-14}$ to $4.7 \times 10^{-13} \mathrm{~m}^{2}$ (16 to $\left.480 \mathrm{md}\right)$. Between $1,830-3,050 \mathrm{~m}(6,000-10,000 \mathrm{ft})$, porosity and permeability decline to about $15-23$ percent and $7.9 \times 10^{-15}$ to $1.9 \times 10^{-13} \mathrm{~m}^{2}$ ( 8 to 192 $\mathrm{md})$. In the few deep sandstones between 3,050-3,660 $\mathrm{m}(10,000-12,000 \mathrm{ft})$ for which data is available, these parameters are further reduced to 12 to 14 percent and $8.9 \times 10^{-15}$ to $3.9 \times 10^{-14} \mathrm{~m}^{2}$ (9 to $40 \mathrm{md}$; DOGGR, 1991).

Modelo sandstones have produced over 200 millions of barrels of oil. Fields in which reported production is not commingled with other zones include the Newhall-Potrero $\left(12 \mathrm{Mm}^{3}\right.$ oil (77 MMBO) and $3.20 \mathrm{Gm}^{3}$ gas (113 BCFG)), Castaic Junction (4.9 $\mathrm{Mm}^{3}$ oil (31 MMBO) and 1.6 $\mathrm{Gm}^{3}$ gas (57 BCFG)), Honor Rancho (4.9 $\mathrm{Mm}^{3}$ oil (31 MMBO) and $1.5 \mathrm{Gm}^{3}$ gas (53 BCFG)), and Ramona (3.7 $\mathrm{Mm}^{3}$ oil (23 MMBO) and $1.2 \mathrm{Gm}^{3}$ gas (43 BCFG)) fields.

The Pliocene Pico Formation is a thick section of neritic to bathyl turbidite and fan deposits that exceeds 3,050 $\mathrm{m}(10,000 \mathrm{ft})$ thick in the basin center. It consists of bedded arkosic sandstones and shales, with sandstones ranging from thin stringers to $>100 \mathrm{~m}$ (hundreds of feet). Sandstone often comprises more than half the formation's thickness. In known oil fields, average reservoir thickness ranges from less than $60 \mathrm{~m}(100 \mathrm{ft})$ to 1,525 $\mathrm{m}(5,000 \mathrm{ft})$ (Keller, 1995). Depths range from less than $305 \mathrm{~m}(1,000 \mathrm{ft})$ in the Newhall Field on the east side of the basin to over 4,575 $\mathrm{m}$ $(15,000 \mathrm{ft})$ in the Long Canyon Field in the axial portion of the basin midway between Ventura and Santa Paula. Porosities and permeabilities of $20-35$ percent and $6.6 \times 10^{-14}$ to $5.9 \times 10^{-12} \mathrm{~m}^{2}(67$ to $6,000 \mathrm{md})$ are typical of sandstones above $1,830 \mathrm{~m}(6,000 \mathrm{ft})$ deep, but decline to 13 to 20 percent and $8.9 \times 10^{-15}$ to $8.1 \times 10^{-14} \mathrm{~m}^{2}$ (9 to $\left.82 \mathrm{md}\right)$ in sandstones below $3,050 \mathrm{~m}(10,000 \mathrm{ft})$ (DOGGR, 1991). 
Pico sandstones are the most important reservoir in the basin having produced well over a billion barrels of oil. In the giant Ventura Field alone, they have produced over $153 \mathrm{Mm}^{3}$ oil (963 $\mathrm{MMBO}$ ) and $60 \mathrm{Gm}^{3}$ gas (2.0 TCFG) from $\sim 1,000 \mathrm{~m}$ (several thousand feet) sandstone between $1,122-3,660 \mathrm{~m}(3,680-12,000 \mathrm{ft})$ on a faulted anticline exhibiting more than $1,050 \mathrm{~m}(3,450 \mathrm{ft})$ of relief. The nearby Rincon Field has produced over $25.3 \mathrm{Mm}^{3}$ oil (159 MMBO) from Pico sands on a smaller faulted anticline between and 1,035 and 3,960 $\mathrm{m}(3,400$ and 13,000 ft) deep (DOGGR, 1991).

A sandstone isopach map for the Ventura Basin reveals three thick east-west trending sandstone zones, each exceeding $1,220 \mathrm{~m}(4,000 \mathrm{ft})$ thick, as well as significant sandstone development exceeding $300 \mathrm{~m}(1,000 \mathrm{ft})$ throughout most of the basin (Figure 5). In the deeper parts of the basin, sandstones within the isopach interval include primarily Sespe through Pico formation sandstones. Increasing contributions of Cretaceous strata, at the expense of these Eocene through Pliocene deposits, occupy the isopach interval in the shallower basin margins.

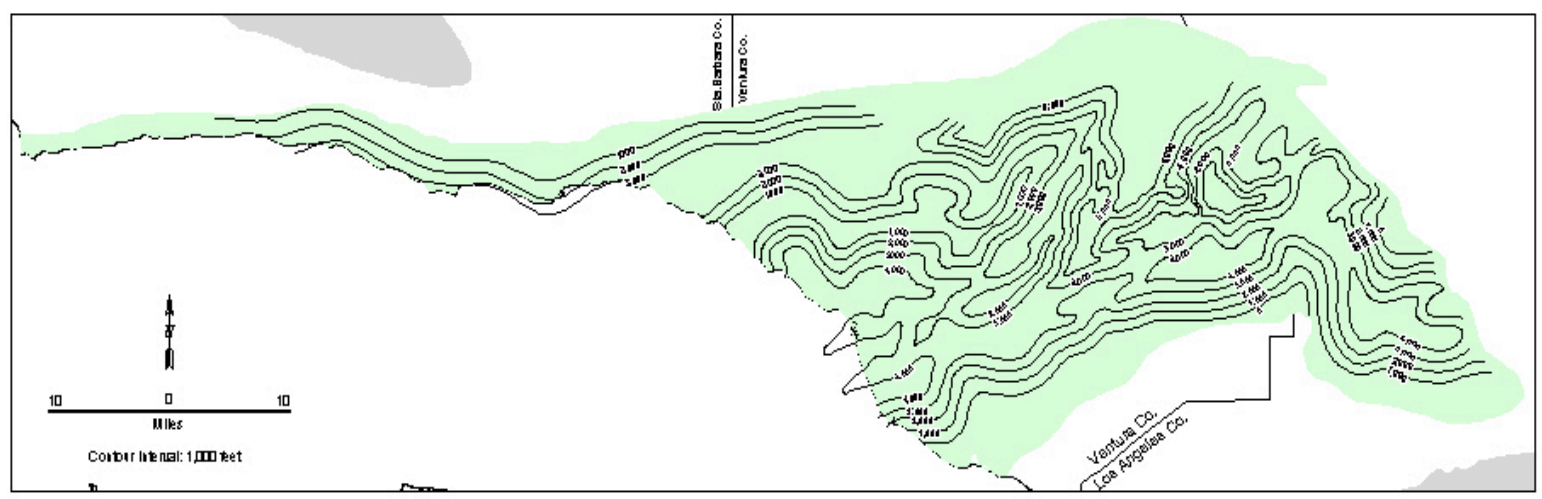

Figure 5. Ventura Basin - gross sandstone isopach map for depth interval 800-3,050 m $(2,625-10,000 \mathrm{ft}$; or basement).

\subsubsection{Peninsular Ranges Province}

The Peninsular Ranges are a series of mountain ranges in southwest coastal California characterized by intervening northwest trending valleys sub-parallel to faults branching from the San Andreas Fault zone. The Peninsular Ranges are bordered on the north by the Transverse Ranges, on the west by the Channel Islands, and on the east by the Colorado Desert province.

\subsubsection{Los Angeles Basin}

The Los Angeles Basin is the largest of the Peninsular Range basins and the southernmost of the onshore Cenozoic basins that formed along the continental borderland from the middle Miocene through the Holocene. It covers about $3,885 \mathrm{~km}^{2}$ (1,500 sq. mi.) and is bordered on the north by the Santa Monica-Hollywood-Raymond Hill Fault Zone and the Santa Monica Mountains; on the northeast by the Sierra Madre Fault and the San Gabriel Mountains; on the east and southeast by 
the Chino Fault, Santa Ana Mountains, and the San Joaquin Hills; and on the west and southwest by the Palo Verdes Fault. The basin contains a thick section of primarily Miocene and Pliocene sedimentary rocks estimated to be over $8,230 \mathrm{~m}(27,000 \mathrm{ft})$ thick (Figure 6). The basin is considered the world's richest in terms of hydrocarbons per unit volume of sedimentary fill and contains three supergiant fields, the Wilmington, Huntington Beach, and Long Beach fields. Collectively, these three fields contain about 52 percent of the basin's recoverable reserves (Biddle, 1991).

The Los Angeles Basin is a structurally complex basin located within the San Andreas Transform system at the intersection of the Peninsular Ranges and Transverse Ranges. Its evolution commenced with mid-Miocene extension associated with strike-slip and rotation of the Transverses Ranges and persisted through the late Miocene to early Pliocene extension associated with the opening of the Gulf of California (Biddle, 1991). During the late Miocene to early Pleistocene, the basin underwent its principle phase of subsidence and deposition, after which it was subjected to post mid-Pleistocene north-to-south compression resulting in extensive folding and thrust faulting of the Neogene section (Biddle, 1991, Yerkes et al., 1965). In its present form, the basin is broken by many faults and folds, the most important being the Palos Verde, Newport-Inglewood, and Whitier fault zones, which divide the basin into several distinct fault blocks.

The southwestern block is bounded on east by the Newport-Inglewood Fault Zone, a linear trend of extensive folding and faulting which has localized major oil fields along its length. The main structural features of the southwestern block are the anticlinal Palos Verde Hills, uplifted along a steep reverse fault exposing basement Catalina Schist at the surface and forming several basement anticlinal ridges over which younger sediments have been draped, forming important oil pools including the most productive field in the state, the Wilmington Field.

The central block, between the Newport-Inglewood and the Whittier Fault zones, forms the axial trough of the basin. Little is known of the basement rocks in this part of the basin since the deepest well bottomed at a depth of 6,322 m (20,736 ft) in lower Pliocene Repetto Formation beds.

The northeastern block lies between the Whittier Fault Zone and the San Gabriel Mountains. The Whittier Fault is a north dipping reverse right-oblique fault along which several important major oil fields are localized including the Brea-Olinda, Sansinena, and Whittier fields. This block is a deep synclinal basin that contains mostly marine Cretaceous sedimentary rocks.

Sedimentary rocks deposited before the Miocene opening of the Los Angeles Basin are unrelated to the present depositional basin. These rocks include late Cretaceous through Miocene fore-arc basin deposits and volcanic and sedimentary rocks of the Topanga Group. The Topanga Group and earlier rocks are deeply buried and poorly understood throughout most of the Los Angeles Basin. Hence, they are not considered in this survey as potential objective for $\mathrm{CO}_{2}$ sequestration. 


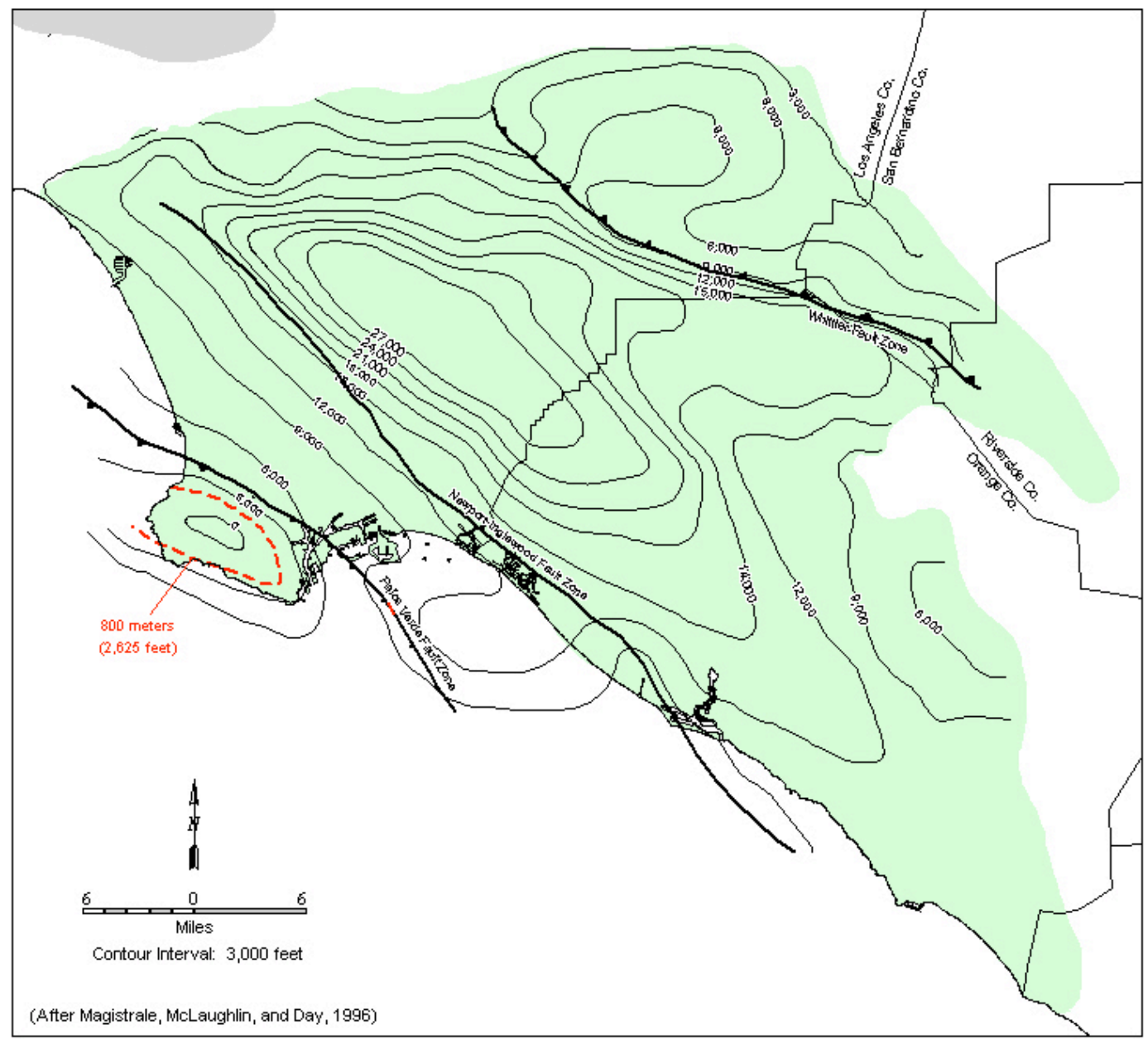

Figure 6. Los Angeles Basin - depth-to-basement map.

Throughout much of the Los Angeles Basin, the Puente Formation overlies the Topanga Formation. The Puente Formation consists of about 2,380 m (7,800 ft) of upper to middle bathyal sediments that can be divided into three general zones - (1) a lower unit ( $\sim 40 \mathrm{~m}$, or $\sim 1,500 \mathrm{ft}$ ) consisting of micaceous and calcareous siltstone and silty medium grained feldspathic sandstone that grades to phosphatic nodular shale in the western part of the basin; (2) a middle zone $(\sim 1,160 \mathrm{~m}$, or $\sim 3,800 \mathrm{ft})$ of medium to coarse feldspathic sandstone interbedded with sandy siltstone and diatomaceous siltstone with lenses of pebble conglomerate; and (3) an upper unit ( $\sim 760 \mathrm{~m}$, or $\sim 2,500 \mathrm{ft}$ ) of fine to coarse grained sandstone interbedded with micaceous sandy siltstone and platy siliceous siltstone with pebble conglomerate (Blake, 1991). Individual sand bodies range from thin stringers to $\sim 100 \mathrm{~m}$ (hundreds of feet) in thickness, but sandstone sequences can contain $\sim 1,000 \mathrm{~m}$ (thousands of feet) of reservoir sandstone.

Producing sandstones range from 150-3,660 m (500 to almost 12,000 ft) deep in the La Mirada Field. Sandstones above $2,440 \mathrm{~m}(8,000 \mathrm{ft})$ average about $20-35$ percent porosity with permeabilities between $3.4 \times 10^{-14}$ and $9.9 \times 10^{-13} \mathrm{~m}^{2}$ (34 and 1,000 md). Deeper sandstones exhibit 
porosities and permeabilities on the order of 15 to 18 percent and $9.9 \times 10^{-15}$ to $1.5 \times 10^{-12} \mathrm{~m}^{2}$ (10 to 1,500 md; DOGGR, 1991).

Puente sandstones produce in at least 50 fields, but reported production is usually commingled with shallower Repetto and Pico formation reservoirs. Producing fields include the supergiant Wilmington (410 $\mathrm{Mm}^{3}$ oil (2.6 BBO) and $34 \mathrm{Gm}^{3}$ gas (1.2 TCFG)), and Huntington Beach (170 $\mathrm{Mm}^{3}$ oil (1.1 BBO) and $24.0 \mathrm{Gm}^{3}$ gas $\left.(846 \mathrm{BCFG})\right)$ fields, and the giant Long Beach $\left(148 \mathrm{Mm}^{3}\right.$ oil (932 MMBO) and $30.81 \mathrm{Gm}^{3}$ gas $\left.(1,088 \mathrm{BCFG})\right)$, Brea-Olinda (64.2 $\mathrm{Mm}^{3}$ oil (404 MMBO) and $13.2 \mathrm{Gm}^{3}$ gas (467 BCFG)), Inglewood (59.8 $\mathrm{Mm}^{3}$ oil (376 MMBO) and $7.70 \mathrm{Gm}^{3}$ gas (272 BCFG)), and Santa Fe Springs (99.2 $\mathrm{Mm}^{3}$ oil (624 MMBO) and $23.7 \mathrm{Gm}^{3}$ gas (837 BCFG)) fields.

Overlying the Puente Formation is a thick section of Pliocene deposits consisting of a lower unit, the Repetto Formation and an upper unit, the Pico Formation. The lower Pliocene Repetto Formation is the most extensive Pliocene unit in the basin and has previously been identified as an important potential target for $\mathrm{CO}_{2}$ sequestration (Hovorka et al., 2003).

The Repetto Formation occurs throughout most of the basin at depths of $305 \mathrm{~m}(1,000 \mathrm{ft})$ to over $3,050 \mathrm{~m}(10,000 \mathrm{ft})$ in the deep central block trough where it exceeds $1,525 \mathrm{~m}(5,000 \mathrm{ft})$ thick. It thins to the southeast toward the San Joaquin Hills and to southwest and northeast to less than $305 \mathrm{~m}(1,000 \mathrm{ft})$. The Repetto Formation represents the deposits of a southward prograding lower bathyal submarine fan and includes submarine channel sandstones, channel levee sands, and broad lobate fan facies sandstones interbedded with siltstones and mudstones. Southward from the central basin, the Repetto sandstones grade chiefly into distal fan facies. Lateral facies changes can be abrupt with porous sandstones grading rapidly into silty mudstones and abyssal mudstones. While many individual Repetto sandstones range from $\sim 1 \mathrm{~m}$ (a few feet) to tens of meters (a few tens of feet) thick, aggregate sandstone thickness within fan deposits can approach $\sim 1000 \mathrm{~m}$ (several thousand feet) in the basin center.

Nearly all producing Repetto sandstones occur at depths from 305-2,315 m (1,000-7,600 ft) with porosities of 20 to 34 percent and permeabilities of $3.9 \times 10^{-14}$ to $3.2 \times 10^{-12} \mathrm{~m}^{2}$ (40 to 3,220 md). Only in the Potrero and Buena Park East fields do deeper reservoir sandstones occur at depths of 2,490-2,815 $\mathrm{m}(8,170-9,240 \mathrm{ft})$ where porosity and permeability of 19 percent and $8.9 \times 10^{-15} \mathrm{~m}^{2}(9 \mathrm{md})$ are reported (DOGGR, 1991).

The Repetto is a major petroleum reservoir in the basin. It has produced in at least 33 fields to various degrees with major commingled production in the aforementioned supergiant and giant Wilmington, Huntington Beach, Long Beach, Brea - Olinda, and Santa Fe Springs fields. Trapping mechanisms are dominantly structural in faulted anticlines and overturned beds along the basin's main fault trends. Smaller stratigraphic traps are not uncommon given the lateral heterogeneity of the turbidite sands. Interbedded siltstones and mudstones provide local seals while overlying Pico Formation shales form a more regional seal up to $\sim 100 \mathrm{~m}$ (many hundreds of feet) thick. However, the trapping capacity of the Pico Formation is controlled by Repetto facies distribution and considerable relief on the pre-Pico unconformity that can be on the order of over tens of meters (hundreds of feet) (Henry, 1987). This results in areas where lower Pico 
shales form upwards of over $245 \mathrm{~m}$ (800 ft) of seal for Repetto sandstones and areas where Pico sandstones rest directly upon Repetto sandstones.

The Repetto is unconformably overlain by inner neritic to upper bathyl shales of the upper Pliocene-lower Pleistocene Pico Formation. The Pico Formation consists of submarine fans and shales that continued to fill the basin for the remainder of the Pliocene and most of the Pleistocene. Throughout most of the basin, the Pico Formation is too shallow for $\mathrm{CO}_{2}$ sequestration. The formation reaches a maximum thickness and depth in a portion of the central trough near Buena Park East and La Mirada fields where the formation ranges from 1,250-1,370 $\mathrm{m}(4,100-4,500 \mathrm{ft})$ thick and 2,045-2,440 $\mathrm{m}(6700-8,000 \mathrm{ft})$ deep. It thins and rises rapidly to the northeast, northwest, and southwest to only 455-610 m (1,500-2,000 ft) thick with the base of the formation only $610-915 \mathrm{~m}(2,000-3,000 \mathrm{ft})$ deep in nearby fields. Where data is available, reported porosities range from 30 to 39 percent and permeabilities from $2.0 \times 10^{-13}$ to $5.8 \times 10^{-12} \mathrm{~m}^{2}$ (200 to 5,900 md) (DOGGR, 1998).

A few shallow and thin Pico sandstones produce small volumes of oil and gas at depths from 290-915 m (950-3,000 ft), but in all cases production is commingled with Puente and/or Repetto production.

A sandstone isopach map for the Los Angeles Basin indicates that more than 1,525 $\mathrm{m}(5,000 \mathrm{ft})$ of sandstone is present within the isopach interval in the central basin and that sandstone thickness generally correlates with relative basement depth (Figure 7). The thicker sandstone reflected in the basin center is dominated by Puente, Repetto, and Pico formation sandstones but in the shallower basin margins, Topanga Formation and older units become locally important in the mapped interval.

\subsubsection{Coast Ranges Province}

California's Coast Ranges are composed of a series of northwesterly trending coastal mountain ranges and valleys extending southward from the Oregon state line to the Transverse Ranges in Santa Barbara and Ventura counties. To the east, they are bounded by the Coast Range Thrust, along which older Mesozoic rocks are thrust over Cretaceous rocks of the Great Valley Sequence in the Sacramento and San Joaquin basins.

The Coast Ranges include several Cenozoic marine sedimentary basins, some of which have produced significant volumes of oil and natural gas. From north to south, these basins include the Eel River, Livermore, Orinda, Sonoma, La Honda, Salinas, and Cuyama basins. While some of these basins are considerably smaller than other California marine basins, they nonetheless contain thick sequences of marine sands and shales. However, many of these basins are poorly explored and lack deep well control.

\subsubsection{Eel River Basin}

The Eel River Basin, located in Humboldt County, is the onshore expression of a much larger offshore Cenozoic forearc basin. The onshore portion is expressed as a westerly plunging syncline. While the Freshwater Fault technically bounds the basin on the northeast, its northeast 
margin is more practically defined by the northeasterly dipping Little Salmon Thrust Fault. To the south, the basin is bounded by the Russ Fault, north of which the upturned beds of the Yager Formation and lower Wildcat Group are exposed.

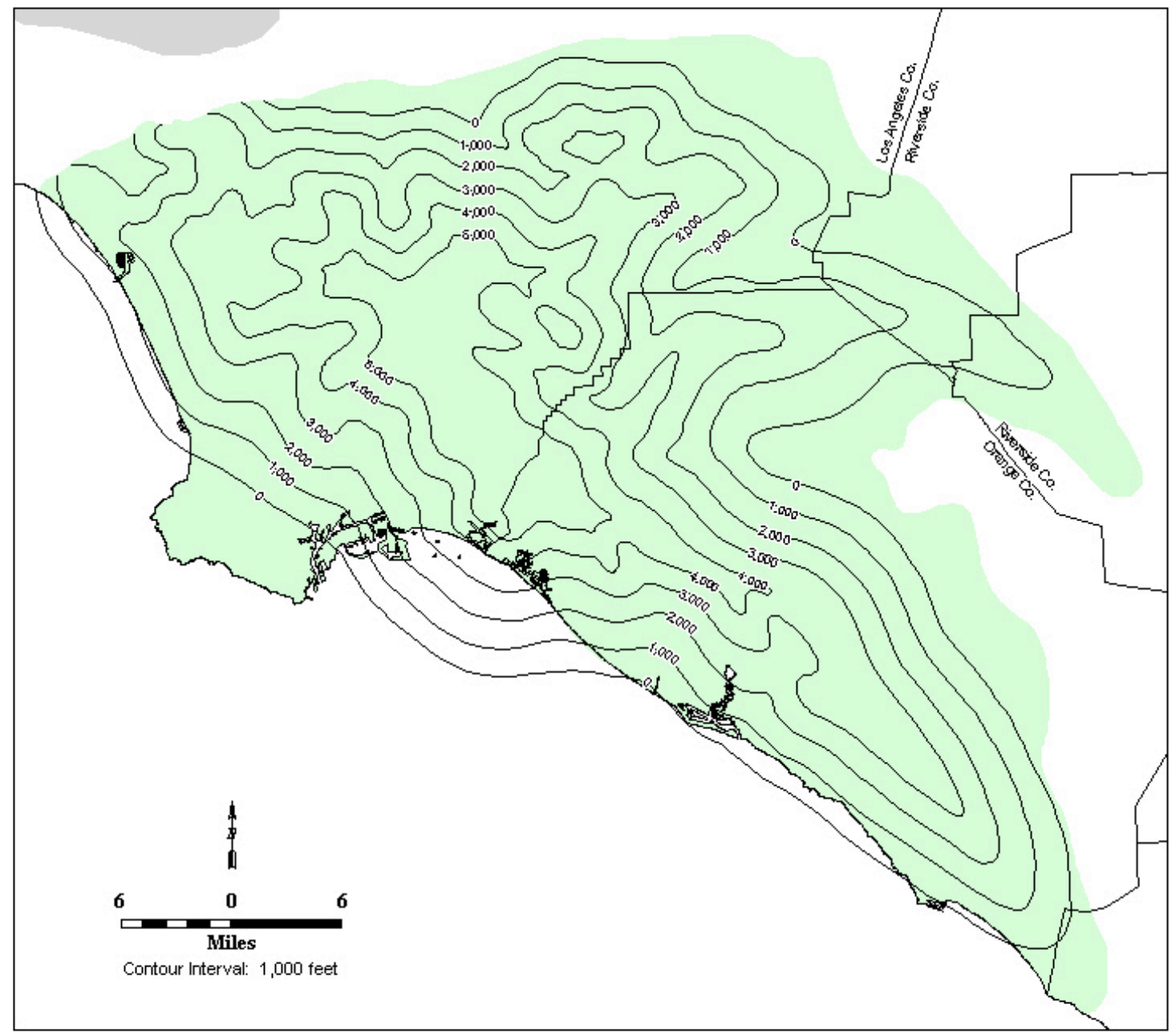

Figure 7. Los Angeles Basin - gross sandstone isopach map for depth interval 800-3,050 m $(2,625-10,000 \mathrm{ft}$; or basement).

The basin contains more than $3,810 \mathrm{~m}(12,500 \mathrm{ft})$ of sedimentary fill including over $3,355 \mathrm{~m}$ $(11,000 \mathrm{ft})$ of dominantly Neogene marine, sandstone, siltstone and shale resting on sandstones, conglomerates, and shales of the Cretaceous Yager Formation. In outcrop, the Yager Formation unconformably rests on basement rocks of the Jurassic Franciscan Complex. The basin is only lightly drilled with no wells having penetrated basement. Hence, an extrapolation to basement, adapted from Hopps and Horan's (1983) shallower Eel River Formation structure map, was used to generate a depth-to-basement map which indicates that most of the basin contains sufficient sedimentary fill for potential $\mathrm{CO}_{2}$ sequestration (Figure 8). 
Due to their depth, Yager Formation beds are poorly defined in the subsurface, but outcrops reveal they are dominantly marine shale, mudstone, and siltstone with interbedded graywacke and conglomerate. Ogle (1968) concluded that these rocks were not of hydrocarbon reservoir quality, except where fractured. Consequently, these beds are considered unlikely candidates for carbon sequestration.

Lower-middle Miocene Bear River beds unconformably overly the Yager Formation, but are confined to the deeper axial portion of the basin. A pronounced unconformity truncates the beds to the north and south along the basin flanks. Due to their depth and distribution, Bear River rocks are less well known than the more extensive overlying upper Miocene and younger units. Where encountered, they consist of bathyl marine units comprised of deep-water sandstones enclosed in siliceous mudstone. Sandstones generally range from 6-37 m (20-120 ft) thick but may reach as much as $610 \mathrm{~m}$ (2,000 ft) thick (Hopps and Horan, 1983; Stanley, 1995b). Gas shows have been reported in the Bear River sandstones, but no commercial production has been established.

Bear River beds are unconformably overlain by the Wildcat Group, containing the only commercial hydrocarbon producing reservoirs in the basin. It consists of a lower sequence of

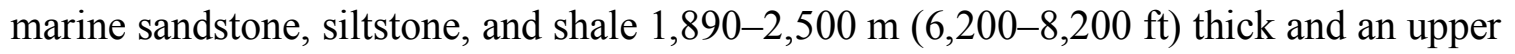
nonmarine sequence of braided delta plain deposits 800-1,000 m (2,625-3,280 ft) thick (Clarke, 1987). In ascending order, the group is composed of the Pullen, Eel River, and Rio Del formations, the Scotia Bluffs Sandstone, and the nonmarine Carlotta Formation (Nilsen and Clarke, 1987).

The Pullen Formation consists of deep-water siliceous clastic sediments. Sandstones are typically 5-6 $\mathrm{m}$ (15-20 ft) thick, with porosities of 12-30 percent and permeabilities of more than 3.0x10${ }^{13} \mathrm{~m}^{2}$ (300 md; Stanley, 1995b). Gas shows have been reported in the Pullen, but no production has been established.

The Pliocene section consists of prograding deep sea fan to shallow marine sediments of the Eel River and Rio Dell formations (Crouch and Bachman, 1987). Eel River sandstones are as much as $185 \mathrm{~m}(600 \mathrm{ft})$ thick with porosities of 15 to 30 percent and permeabilities of $3.9 \times 10^{-15}$ to $2.1 \times 10^{-14} \mathrm{~m}^{2}$ (4 to $21 \mathrm{md}$ ) (Stanley, 1995b). In 1964, gas was discovered in sandstones between $1,370-1,615 \mathrm{~m}(4,500-5,300 \mathrm{ft})$ on a small anticline with about $105-135 \mathrm{~m}(350-450 \mathrm{ft})$ of closure. The early wells never produced, but these sandstones are receiving renewed attention and is currently undergoing development drilling.

Rio Dell Formation sandstones are deep sea fan channel and lobe deposits with some of the shallower sands being shelf and near shore deposits. Sandstones are lenticular, fine to very fine grained, and range from $<1-46 \mathrm{~m}(1-150 \mathrm{ft})$ thick but locally may reach as much as $305 \mathrm{~m}$ $(1,000 \mathrm{ft})$ thick (Stanley, 1995b). Porosity ranges from 22-28 percent with permeabilities of $9.9 \times 10^{-16}$ to $1.2 \times 10^{-14} \mathrm{~m}^{2}$ (1 to $12 \mathrm{md}$; DOG, 1983).

Since 1937, Tompkins Hill Field has produced more than $3.31 \mathrm{Gm}^{3}$ gas (117 BCFG) from middle and lower Rio Dell sandstones between 640-1,770 m (2,100-5,800 ft). Sandstones produce in structural closure and in stratigraphic traps on the flanks of an anticline displaying 
about $365 \mathrm{~m}$ (1,200 ft) of closure (Stanley, 1995b). The main producing sand is about $15 \mathrm{~m}$ (50 $\mathrm{ft}$ ) thick but thickens abruptly to the southeast. In the abandoned Table Bluff Field, gas was discovered in an anticlinal fold in 1960, and abandoned in 1968 after producing only $3 \mathrm{Mm}^{3}(0.1$ BCFG) from Rio Dell sandstones between 640-1,455 m (2,100-4,775 ft). Sandstones are generally $<1-3 \mathrm{~m}(1-10 \mathrm{ft})$ thick, but net pay zones may be 5-90 $\mathrm{m}(15-300 \mathrm{ft})$ thick with porosities of 22-27 percent (DOG, 1983). The Table Bluff anticline has about $610 \mathrm{~m}(2,000 \mathrm{ft})$ of closure.

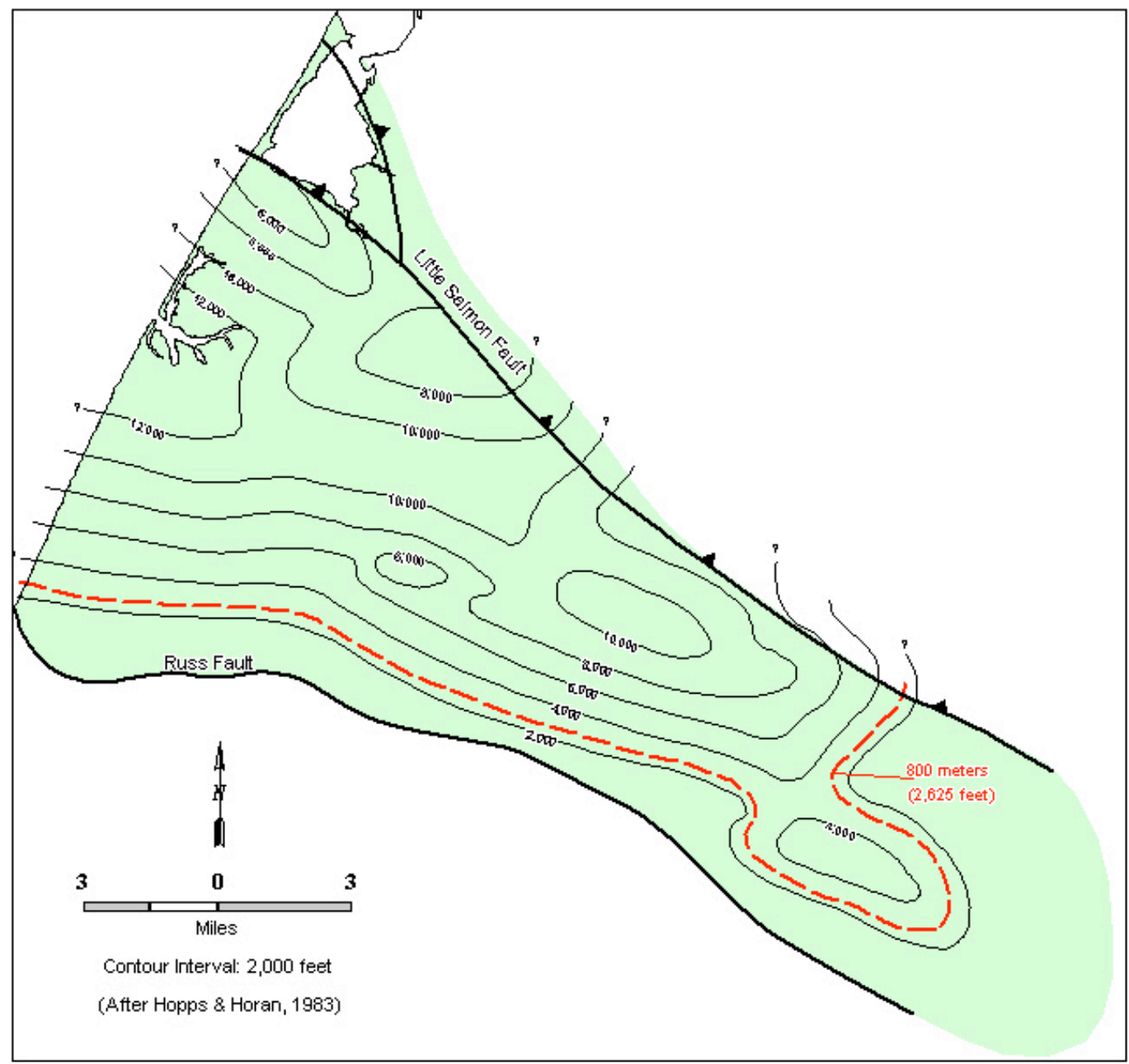

Figure 8. Eel River Basin - depth-to-basement map.

The shallow marine to nonmarine Pleistocene Carlotta and Scotia Bluffs formations, and sediments of the Pleistocene Hookton formation are the youngest units in the basin. With the exception of some lower Carlotta beds near the basin axis, most of these units are too shallow to be considered for potential $\mathrm{CO}_{2}$ sequestration. 
Sandstones in the Bear River Beds through Rio Dell Formation may provide carbon sequestration opportunities in the deeper parts of the basin on anticlinal closures and flanking stratigraphic pinch outs. While individual sandstones are generally thin, a sandstone isopach map reveals a northwesterly trending zone of sandstone, in excess of $760 \mathrm{~m}(2,500 \mathrm{ft})$ thick, paralleling the north flank of the basin (Figure 9). Enclosing siliceous mudstones and shales should provide seals.

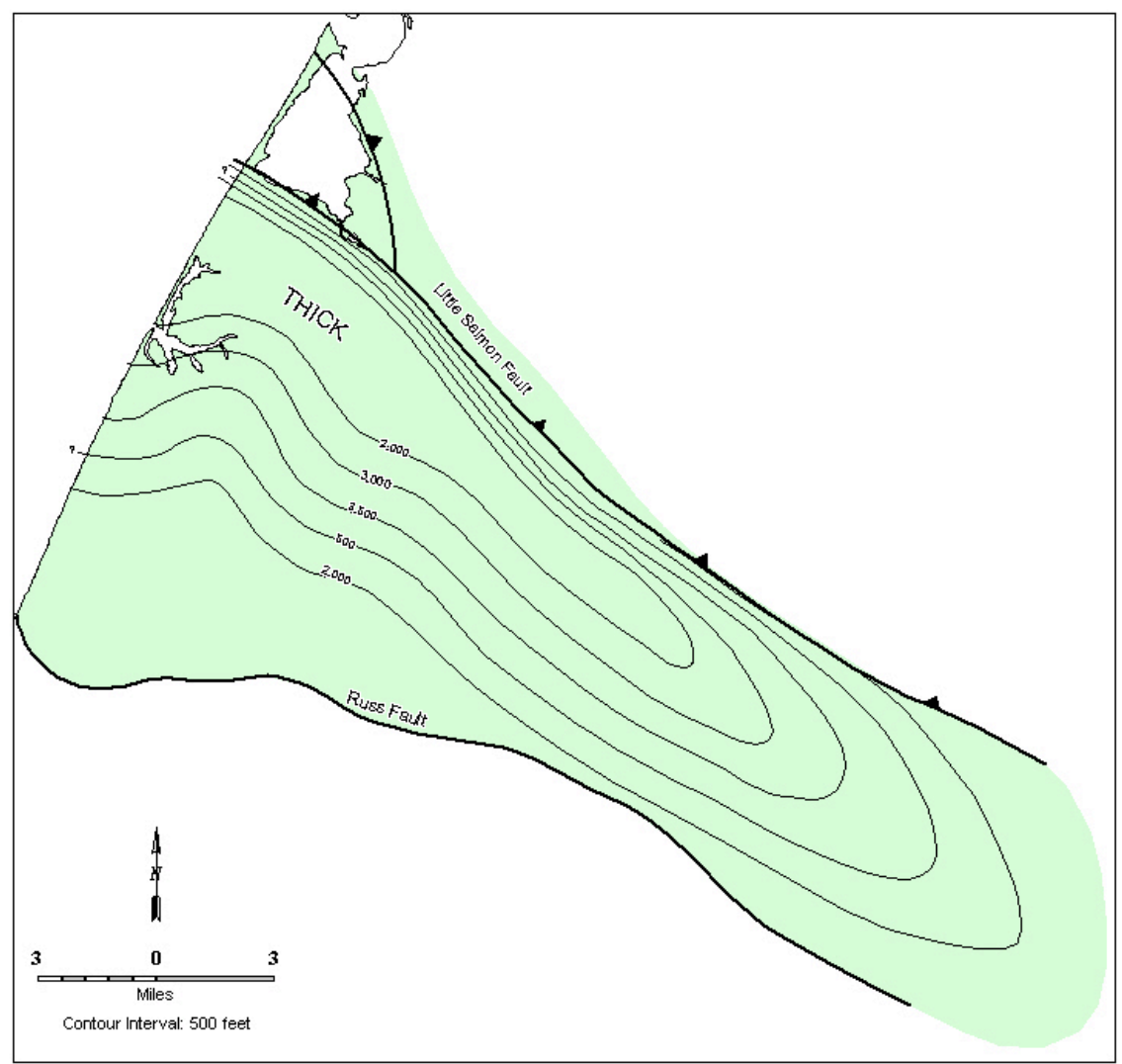

Figure 9. Eel River Basin - gross sandstone isopach map for depth interval 800-3,050 m $(2,625-10,000 \mathrm{ft}$; or basement).

\subsubsection{Salinas Basin}

The Salinas Basin is one of several hydrocarbon producing Cenozoic marine sedimentary basins west of the San Andreas Fault including the La Honda Basin to the northwest and the Cuyama basin to the southeast. The basin is a narrow, northwest-trending feature extending almost 225 $\mathrm{km}$ (140 mi.) from Monterey County southeastward into San Luis Obispo County, and varying in width from less than $16 \mathrm{~km}$ (10 mi.) to $48 \mathrm{~km}$ (30 mi.). It is bordered on the east by the San Andreas Fault. To the northeast, the basin narrows where Salinian granitic basement rocks are uplifted and exposed in the Gabilan Range. The western basin margin is defined by the JolanRinconda Fault Zone and uplifted granitic and metasedimentary rocks of the Santa Lucia Range. 
The structural and lithologic framework of the Salinas Basin consists of a series of tectonic basement blocks assembled during a complex history of subduction and transform motion along plate boundaries. During the Miocene, the plate boundary between the Pacific Plate and the North American Plate evolved into a transform boundary represented by the San Andreas Fault Zone. Basement rocks representing the subduction phase, and characterized by the Franciscan Complex, are present east of the San Andreas Fault Zone, against which transform motion has juxtaposed allochthonous Cretaceous granitic plutonic rocks and metamorphic basement rocks of the Salinian Terrane to the west. Rocks of the Salinian Terrane are thought to have been transported over 1,600 km (1,000 mi.) northward by transform motion along the San Andreas Fault Zone.

The basin is floored by a complex of Cretaceous granitic plutons and metamorphic rocks that are exposed in the Gabilan Range and dip westward towards the basin axis. Basement is overlain by a thick sequence of Cretaceous marine sediments to Pleistocene marine and nonmarine sedimentary rocks. The deepest well drilled in the basin bottomed in the Monterey Formation at 6,096 m (19,994 ft) (Stanley, 1995b). A generalized depth-to-basement map is shown in Figure 10.

Cretaceous rocks and beds of the lower Miocene Berry Formation, Vaqueros Sandstone, and Sandholt Shale onlap granitic Salinian basement. Little information is available regarding these units but sandstone developments are indicated on well logs. These rocks are overlain by the Monterey Formation, which throughout much of the shallower east flank of the basin, onlaps basement of the Gabilan shelf. The Monterey is conformably overlain by the Miocene Santa Margarita Formation, diatomaceous and silty mudstones of the Pliocene Pancho Rico Formation, and non-marine pebble beds, silica cemented sands and calcareous fresh water clays of the PlioPleistocene Paso Robles Formation. The Santa Margarita, Pancho-Rico, and Paso Robles beds are widely exposed throughout the basin in terraces along the lower elevations of the Gabilan Range and are generally too shallow to be considered for potential sequestration purposes.

Where the Monterey Formation onlaps basement, it contains significant sandstone deposits of nearshore, shelf, and turbidite origin which comprise the principal reservoirs in the basins three largest oil fields, the San Ardo, King City, and Monroe Swell fields. Monterey sandstones range in thickness from thin stringers up to $150 \mathrm{~m}(500 \mathrm{ft})$, but aggregate sandstone within the formation can total as much as $455 \mathrm{~m}(1,500 \mathrm{ft})$. Producing sandstone depths are shallow, ranging from 565-975 $\mathrm{m}(1,860-3,200 \mathrm{ft})$, but well control indicates Monterey deposits extend to at least $6,100 \mathrm{~m}(20,000 \mathrm{ft})$. Reported porosities in the shallow sands range from 15-39 percent with permeabilities of $4.9 \times 10^{-13}$ to $7.9 \times 10^{-12} \mathrm{~m}^{2}$ (500-8,000 md; DOGGR, 1991).

The San Ardo Field is the largest Monterey accumulation, having produced $73.9 \mathrm{Mm}^{3}$ oil (465 MMBO) and $2.2 \mathrm{Gm}^{3}$ gas (77 BCFG) from offshore bars and shoreline sandstones that onlap a shallow granitic basement ridge (Baldwin, 1950; Colvin, 1963). The King City Field has produced almost $0.3 \mathrm{Mm}^{3}$ oil (2 MMBO) and $20 \mathrm{Mm}^{3}$ (0.6 BCFG) from the Monterey Thorup Sandstone, a near shore or turbidite deposit along the hingeline between the granitic high on the east and the marine basin to the west. The field area is characterized by numerous northwest southeast trending faults and anticlines, with many having steep overturned flanks (Church, 1963). The Monroe Swell Field has produced $111 \times 10^{3} \mathrm{~m}^{3}$ oil $(695 \mathrm{MBO})$ and $3 \mathrm{Mm}^{3}$ gas $(0.1$ 
BCFG) from structural and stratigraphic traps. Smaller fields such as the Paris Valley, Lynch Canyon, McCool Ranch, and Quinado Canyon fields have produced smaller volumes of oil ranging from $1.6 \times 10^{3} \mathrm{~m}^{3}$ oil $(10 \mathrm{MBO})$ to $50.1 \times 10^{3} \mathrm{~m}^{3}$ oil $(315 \mathrm{MBO})$ from shallow Monterey sandstones.

While the Monterey sands in the known oil fields are too shallow for potential sequestration purposes, deeper Monterey sandstones exist farther west in the deeper basin. A gross sandstone isopach map (Figure 11) shows sandstone developments thickening to over $760 \mathrm{~m}(2,500 \mathrm{ft})$ to the southwest towards the basin axis. Underlying poorly known lower-middle Miocene and Cretaceous sandstones may also be present at depth. 


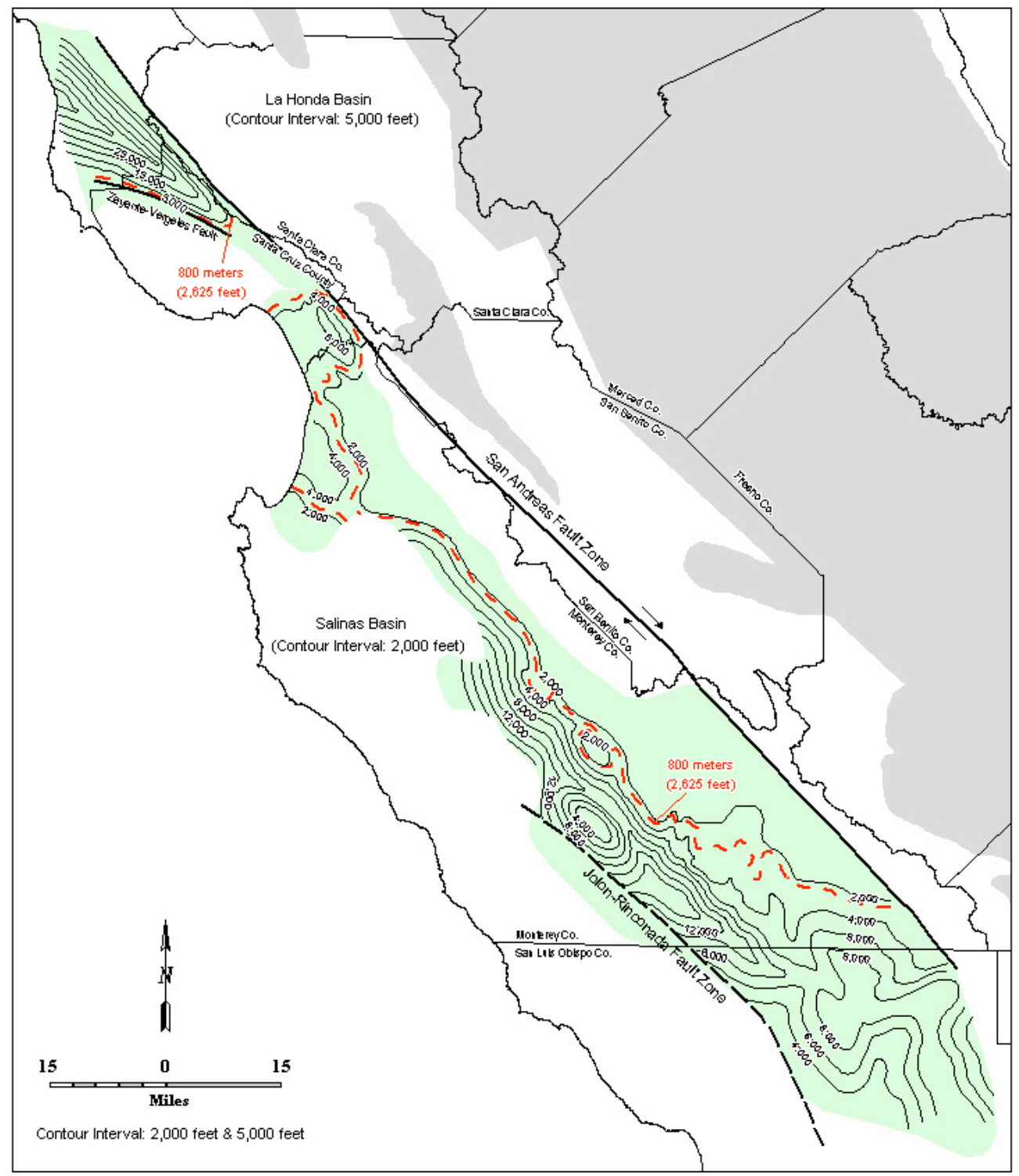

Figure 10. Salinas and La Honda basins - depth-to-basement map.

\subsubsection{La Honda Basin}

The La Honda Basin is located north of the Salinas Basin in Santa Clara and Santa Cruz counties between San Francisco and Monterey Bay. The basin is bounded on the northeast by the San Andreas Fault, on the northwest by granitic rocks of Montara Mountain, on the southwest by the Zayante-Vergeles Fault, and on the west by the San Gregorgio - Hosgri Fault (Stanley, 1995a). The relatively small basin comprises about $930 \mathrm{~km}^{2}$ (360 sq. mi.) and represents a small sliver of the larger San Joaquin Basin which was displaced approximately $300 \mathrm{~km}$ (185 mi.) by right lateral slip along the San Andreas Fault.

It is estimated that as much as $14,635 \mathrm{~m}(48,000 \mathrm{ft})$ of Tertiary sedimentary and volcanic strata fill the basin (Figure 10). However, no wells have reached basement near the basin axis. The 
basin contains only 4 small shallow oil fields and remains largely unexplored with only about 100 wells drilled to relatively shallow depths. The deeper section is poorly defined or unknown.

Where well logs have revealed the shallow stratigraphy, rocks of the Paleocene Locatelli Formation or overlying lower-middle Eocene Butano Formation rest unconformably on basement. The Locatelli Formation is a poorly understood section identified in outcrop but not positively identified in the subsurface (Stanley, 1995a). Where exposed, it consists of arkosic sandstone, mudstone, and conglomerate thought to be at least $300 \mathrm{~m}$ (985 ft) thick and containing both shelf and turbidite sandstones.

The Butano Formation consists of arkosic turbidite sandstone, mudstone, and conglomerate deposited by northward flowing turbidity currents on a deep sea fan (Nilsen, 1979). Individual sandstones may exceed $60 \mathrm{~m}(200 \mathrm{ft})$ thick but aggregate sand thickness can exceed $915 \mathrm{~m}$ $(3,000 \mathrm{ft})$. Shallow producing sands between $550-760 \mathrm{~m}(1,800-2,500 \mathrm{ft})$ deep exhibit porosities between $15-35$ percent with permeabilities of $3.0 \times 10^{-14}$ to $3.9 \times 10^{-14} \mathrm{~m}^{2}(30-40 \mathrm{md})$ but at depth, these are expected to be considerably reduced. The Butano Formation is conformably overlain by the Twobar Shale and Rices mudstone members of the San Lorenzo Formation which provide a thick overlying seal. The Twobar Shale is widespread and generally ranges from 50-250 m $(165-825 \mathrm{ft})$ thick (Stanley, 1995a). The Rices member is locally as much as $670 \mathrm{~m}(2,200 \mathrm{ft})$ thick.

The San Lorenzo Formation is overlain by sandstone of the Vaqueros Formation except where the Vaqueros is locally absent, where the San Lorenzo Formation is overlain by the Zayante Sandstone and Mindego Basalt (Stanley, 1995a). The Vaqueros Formation is mainly sandstone, mudstone, and conglomerate deposited in environments ranging from deep sea fan to shallow marine shelf. The Vaqueros is overlain by the Lambert Shale and the discontinuous Lampico Sandstone.

Throughout much of the eastern basin, the Miocene Monterey Formation has been removed by erosion, but thickens to the southwest and south where it is present in the subsurface under Monterey Bay and along the western flank of the Salinas Basin to the south. Middle to late Miocene sandstones of the Santa Margarita Formation unconformably overlie rocks ranging from Mesozoic granitic basement to the Miocene Monterey Formation, and are themselves conformably overlain by the Santa Cruz mudstone. Unconformably overlying the Santa Cruz mudstone is the upper Miocene-Pliocene Purisima Formation. The Purisima Formation is widespread throughout the basin, resting on granitic basement rocks to rocks as young as the Santa Cruz mudstone (Stanley, 1995a). The Purisima includes arkosic and volcanic sandstones, conglomerate and mudstone. Sandstones are generally lenticular stringers but may reach as much as $30 \mathrm{~m}$ (100 ft) thick. Shallow Purisima sandstones between $245-825 \mathrm{~m}$ (800 and 2,700 ft) deep exhibit porosities of 22-34 percent and permeabilities of $9.9 \times 10^{-16}$ to $3.9 \times 10^{-14} \mathrm{~m}^{2}(1-40 \mathrm{md}$; DOGGR, 1991).

Four small oil fields have produced a total of over $0.27 \mathrm{Mm}^{3}$ oil (1.7 MMBO) from shallow sandstones between 100-825 m (330-2,700 ft) deep. The largest, La Honda Field, has produced $0.22 \mathrm{Mm}^{3}$ oil (1.4 MMBO) and $42 \mathrm{Mm}^{3}(1.5 \mathrm{BCFG})$, primarily from Butano and Purisima sandstones. The Oil Creek Field has produced only $38.3 \times 10^{3} \mathrm{~m}^{3}$ oil $(241 \mathrm{MBO})$ and $2.2 \mathrm{Mm}^{3}(79$ 
MMCF) gas from steeply dipping, faulted Butano sandstones. The Moody Gulch and Half Moon Bay fields have collectively produced $25.1 \times 10^{3} \mathrm{~m}^{3}$ oil $(158 \mathrm{MBO})$ and $2,200 \mathrm{~m}^{3}(76 \mathrm{MCF})$ from thin shallow San Lorenzo and Purisima sandstones. Traps include anticlinal closures and stratigraphic traps under the regional sub-Purisima unconformity, and stratigraphic tar seal traps (Stanley, 1995a). The small field size and shallow reservoirs offer little practical opportunity for potential $\mathrm{CO}_{2}$ sequestration.

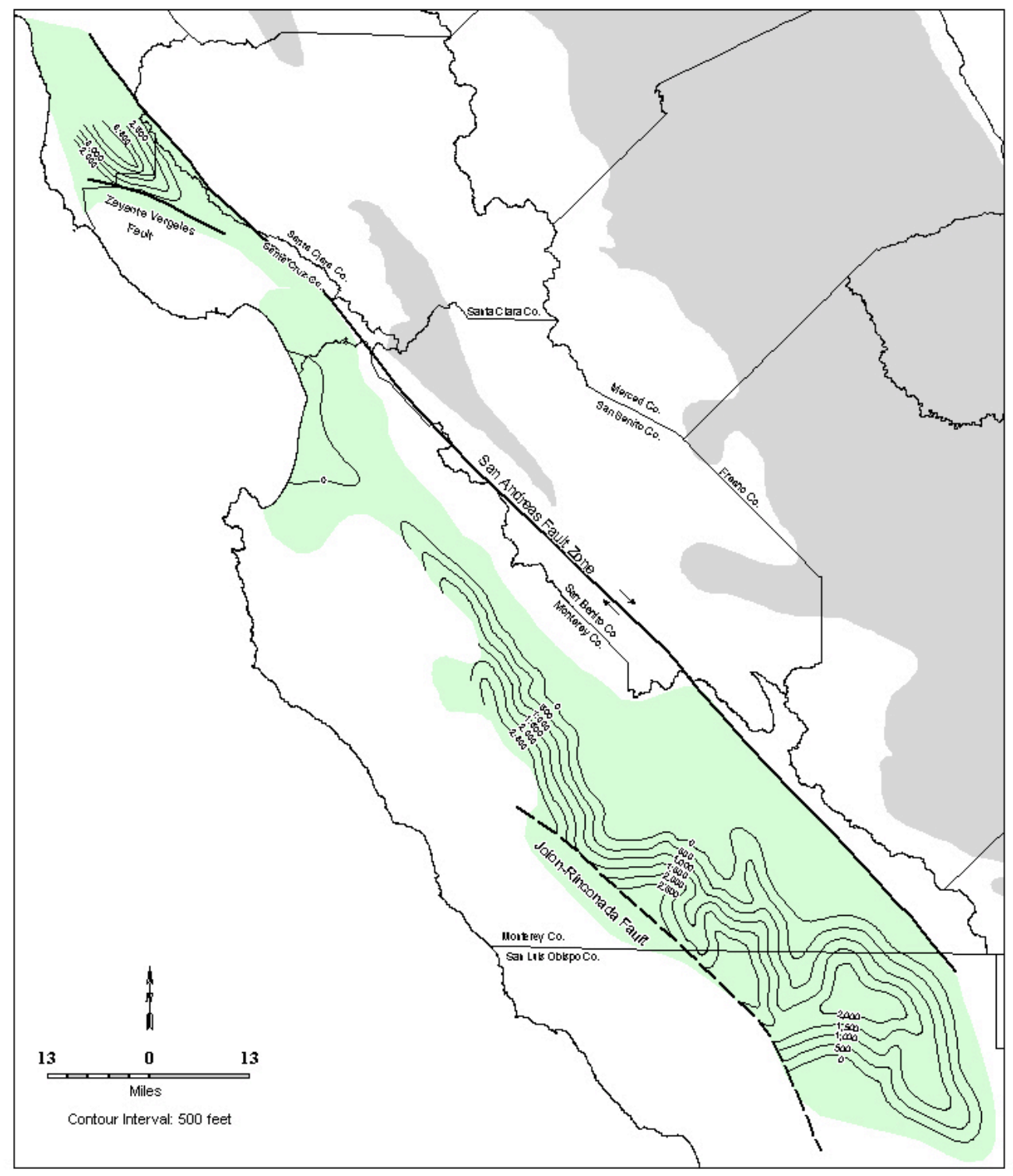

Figure 11. Salinas and La Honda basins - gross sandstone isopach map for depth interval $800-3,050$ m (2,625-10,000 ft; or basement)

In the eastern basin, the Butano and Locatelli formations are too shallow to be considered for $\mathrm{CO}_{2}$ sequestration. Westward, towards the basin center, however, sandstone in the Butano and 
younger formations thickens markedly (Figure 11). The deepest well in the basin, drilled on the Butano Anticline, bottomed in the Butano Formation at 3,370 $\mathrm{m}(11,053 \mathrm{ft})$ and encountered more than 1,220 $\mathrm{m}(4,000 \mathrm{ft})$ of Butano sandstone within the isopach interval. The Vaqueros through Santa Margarita formations are blanketed by the Santa Cruz Mudstone and Purisima Formation, which can attain thicknesses of 2,715 m (8,900 ft) and 2,410 m (7,900 ft) respectively.

\subsubsection{Cuyama Basin}

The Cuyama Basin is a relatively small Cenozoic marine basin near the southern end of the Coast Ranges. It extends approximately 100-120 km (65-75 mi.) in a northwest-southeast direction and varies from 13-29 km (8-18 mi.) wide. It is bounded on the northeast by the San Andreas Fault zone and the Temblor Range, which separate it from the San Joaquin Basin. Its southwest margin is structurally complex and consists of at least two early Miocene wrench faults (Russell and La Panza Faults), which separate the basin from the Sierra Madre Range. The northwest end of the basin is indeterminate, but approaches the southeast end of the Salinas Basin. Its southeastern end is defined by a buried normal fault sub-parallel to the younger Big Pine Fault (Tennyson, 1995).

The basin is located in the southern part of the Salinian block and is floored by granitic and gneissic rocks at considerable depth. Only a handful of wells have encountered deep sub-thrust granitic basement rocks below 5,185 $\mathrm{m}(17,000 \mathrm{ft})$ under the Caliente Range east of the basin. The deepest wells in the central basin bottomed just below 3,965 m (13,000 ft) in the Soda Lake member of the Vaqueros Formation (Spitz, 1988). The lack of basement control or published geophysical maps precluded the construction of a depth-to-basement map.

The basin is structurally complex with extensive normal faulting of the pre-Pliocene section followed by later thrust faulting of the basement through Pliocene section burying much of the sedimentary section below complex thrust sheets. Principle thrust faults include the northeasterly dipping Morales, Taylor Canyon, and Whiterock faults.

Nonmarine mudstones, sandstones, and alluvial gravels of the Oligocene Simmler Formation are presumed to unconformably overly basement throughout much of the basin. The overlying lower and middle Miocene section consists of the Vaqueros Formation, Branch Canyon Sandstone, and Monterey Formation. The Vaqueros Formation is a transgressive-regressive sequence consisting of three principal units; 1) basal transgressive shallow marine sandstone of the Quail Canyon member; 2) transgressive deep marine shale of the Soda Lake member; and 3) an upper unit of regressive clastic deltaic and near shore marine facies of the Painted Rock member. No reliable petrophysical data was available for the Vaqueros sandstones.

During the middle and upper Miocene, the western basin was dominated by marine conditions and the deposition of up to 1,370 m (4,500 ft) of Monterey Formation shale. Eastward, the basin plain shales grade shoreward through distal thin-bedded turbidite sands to thicker proximal turbidite sands. Farther shoreward, shallower marine conditions prevailed with the development of a transgressive - regressive shoreline sequence of interfingering Monterey shale and coarser shelf and shallow marine sediments of the Branch Canyon Sandstone, Painted Rock Sandstone, 
and overlying Santa Margarita Formation. In turn, these units grade landward into nonmarine rocks of the Caliente Formation (Lagoe, 1984). Shallow marine to nonmarine rocks of the Pliocene Morales Formation unconformably overlie the Santa Margarita Formation.

Branch Canyon sandstones are generally 14-30 m (45-100 ft) thick. Porosity has been reported to be about 19 percent at 2,215 m (7,270 ft). No permeability data was available. Painted Rock sandstones are the primary oil reservoirs in the basin. Sandstones range from 15-91 m (50-300 $\mathrm{ft})$ thick but aggregate sandstones can achieve a thickness of 1,830 m (6,000 ft) (Tennyson, 1995). Porosities and permeabilities in reservoir sandstones at depths of 1,250-2,285 m (4,100$7,500 \mathrm{ft}$ ) range from $23-40$ percent and $1.7 \times 10^{-13}$ to $3.9 \times 10^{-13} \mathrm{~m}^{2}(177-400 \mathrm{md})$ respectively. Reported porosities in shallow Santa Margarita sandstones between 560 and $760 \mathrm{~m}(1,830$ and $2,500 \mathrm{ft}$ ) range $30-32$ percent, and permeabilities $6.7 \times 10^{-13}$ to $1.3 \times 10^{-12} \mathrm{~m}^{2}(675-1,300 \mathrm{md})$. Porosity of 30 percent has been reported in a shallow Morales sandstone at $580 \mathrm{~m}(1,900 \mathrm{ft})$ (DOGGR, 1991).

In north central portion of the basin where deep well control exists, a sandstone isopach map (Figure 12) indicates an area of thick sandstone exceeding 1,220 $\mathrm{m}(4,000 \mathrm{ft})$ and aligned in a northwest-southeast orientation roughly paralleling the basin axis. Sandstones within the isopach interval include Branch Canyon and Painted Rock sandstones and overlying Santa Margarita sandstones.

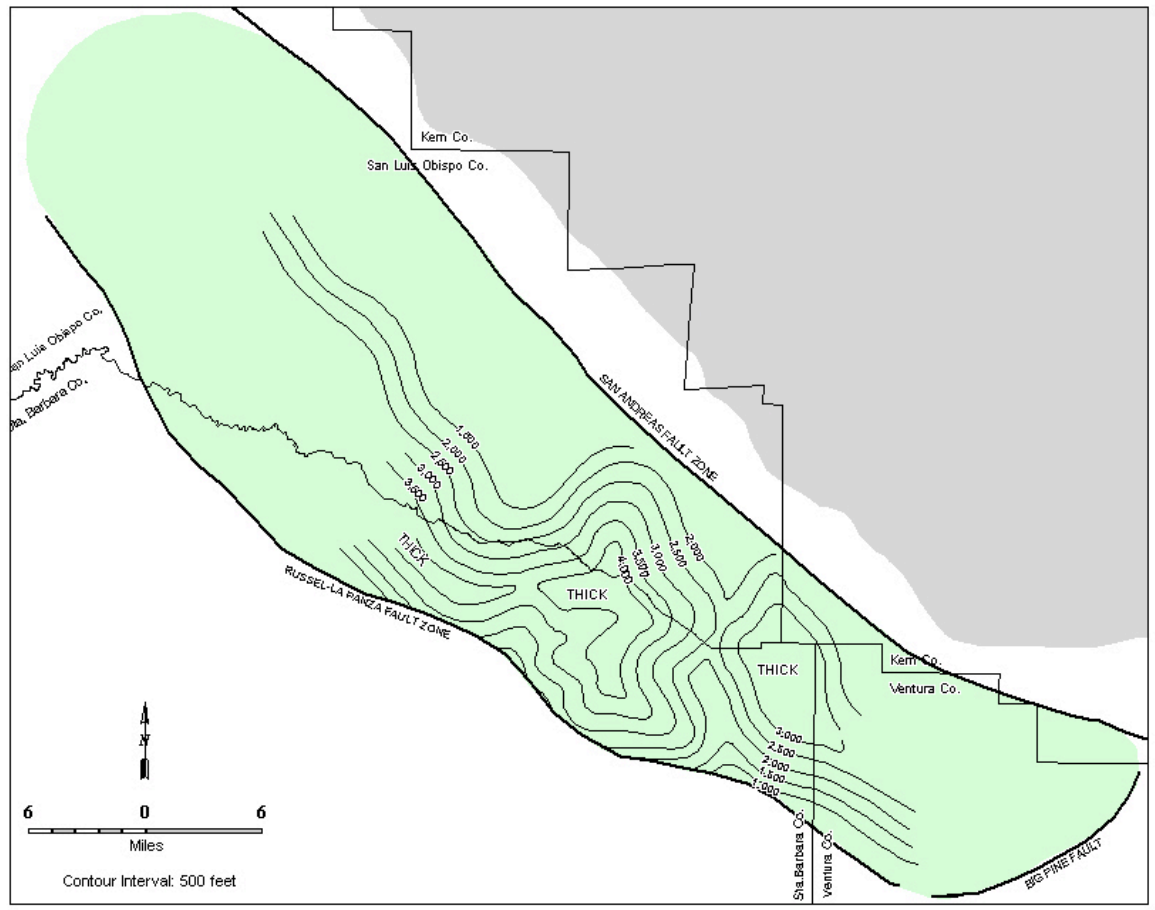

Figure 12. Cuyama Basin - gross sandstone isopach map for depth interval 800-3,050 m (2,625-10,000 ft; or basement). 
Three significant oil fields have been discovered in the basin. The two largest, the South Cuyama Field and the Russell Ranch Field produce from complexly faulted northwest - southeast trending structures. Both fields produce primarily from Painted Rock sandstones. The South Cuyama Field has produced almost $35.5 \mathrm{Mm}^{3}$ oil (223 MMBO) and $2.18 \mathrm{Gm}^{3}$ gas (234 BCFG) from sands between 1,250 and 2,285 m (4,100 and 7,500 ft) deep, while the Russell Ranch Field has produced over $11 \mathrm{Mm}^{3}$ oil (68 MMBO) and $1.4 \mathrm{Gm}^{3}$ gas (49 BCFG) from sands between 795-1,065 m (2,600-3,500 ft) deep. The Morales Canyon Field, has produced $0.40 \mathrm{Mm}^{3}$ oil $(2.5$ $\mathrm{MMBO})$ and $51 \mathrm{Mm}^{3}$ (1.8 BCFG) from small sub-thrust structural and stratigraphic traps in Vaqueros Formation sands a 1,770 $\mathrm{m}(5,800 \mathrm{ft})$ and a shallow Morales Formation sand at $580 \mathrm{~m}$ $(1,900 \mathrm{ft})$.

\subsubsection{Livermore, Orinda, and Sonoma Basins}

The Livermore, Orinda, and Sonoma basins are a related series of deep, linear, Neogene pullapart basins within the Coast Ranges between San Francisco Bay and the Sacramento Basin. All three basins formed under the influence of extensional stresses after the onset of strike-slip motion along the San Andreas and associated Calaveras and Hayward fault systems during the middle Miocene. Right-slip movement provided the shearing motion to open the basins (Magoon, 1995). Widespread volcanism occurred during the filling of the basins and volcanic rocks are especially prevalent in the shallow Pliocene section in the Sonoma Basin.

The basins are filled with thick sections of Miocene and Pliocene sediments resting on an inferred basement of Jurassic-Cretaceous Franciscan Complex rocks which are exposed in the many uplifts surrounding the basins. No wells have been drilled to basement in the axial portions of these basins and no published geophysical basement maps are available, hence no depth-tobasement maps were prepared for these basins. The Livermore Basin contains the most subsurface control with several wells exceeding 3,050 m (10,000 ft) deep. The Orinda Basin has considerably less well control with only 3 wells exceeding 2,745 m (9,000 ft). Very little control is available in the Sonoma Basin with the deepest well bottoming at 2,470 $\mathrm{m}(8,105 \mathrm{ft})$.

The Livermore Basin is approximately $48 \mathrm{~km}$ (30 mi.) long by $19 \mathrm{~km}$ (12 mi.) wide. It is bounded on the north and east by Mount Diablo and the Diablo Range and on the west and southwest by the Calaveras Fault which separates it from the Orinda Basin. Uplifted Franciscan Complex rocks form its southern end. While the deepest well drilled bottomed at $5,305 \mathrm{~m}$ (17,404 ft) in Miocene sediments (Darrow, 1979), outcrop and unpublished geophysical data suggest that the Livermore Basin may be filled with as much as $6,705 \mathrm{~m}(22,000 \mathrm{ft})$ of Eocene, Miocene, and Pliocene sediments that have been extensively folded and faulted by later compressional forces caused by motion on the marginal faults. Outcrops of Eocene marine rocks equivalent to the Capay, Domengene, Nortonville, and Markley formations of the Sacramento Basin dip basinward to depths sufficient for $\mathrm{CO}_{2}$ sequestration. The Miocene section includes the Sobrante, Briones, Cierbo, and Neroly formations. The Sobrante Formation consists of shallow marine sands and pebbly conglomerates. The Briones, Cierbo, and Neroly units make up about $1,370 \mathrm{~m}(4,500 \mathrm{ft})$ of shallow marine to brackish water sands, pebbly conglomerates, and tuffaceous sands and shales (Darrow, 1979). The Neroly Formation is overlain by the Pliocene Orinda Formation, a basin-wide nonmarine sequence of sands, conglomerates, shales, and 
volcanics that may reach a thickness of greater than $4,575 \mathrm{~m}(15,000 \mathrm{ft})$ in the major synclinal areas of the basin (Darrow, 1979).

Well logs indicate sandstone intervals separated by laterally persistent shale units that might be suitable seals for potential sequestration purposes. In the basin's single oil field, the Livermore Field, Eocene Tesla Formation (Domengene equivalent) sandstones at 1,615 m (5,300 ft) exhibit porosities of about 23 percent while reported porosity and permeability in the Miocene Cierbo Formation sandstones between $175-610 \mathrm{~m}(900-2,000 \mathrm{ft})$ average 26 percent and $2.5 \times 10^{-13} \mathrm{~m}^{2}$ (250 md) respectively (DOG, 1983). Cumulatively, these zones have produced $0.29 \mathrm{Mm}^{3}$ oil (1.8 MMBO) from a folded and faulted anticlinal nose. The combined Tesla-Cierbo sandstone interval, which reaches as much as $490 \mathrm{~m}(1,600 \mathrm{ft})$ thick, is overlain by close to $150 \mathrm{~m}(500 \mathrm{ft})$ of overlying upper Cierbo Formation shale. Similar Pliocene and Miocene sand and shale relationships are indicated by the deeper well logs.

In the abandoned Hospital Nose Field, near the south end of the basin, over $610 \mathrm{~m}(2,000 \mathrm{ft})$ of interbedded upper Cretaceous Panoche Formation sandstone occurs at a depth of 1,525 m (5,000 $\mathrm{ft}$ ) and is overlain by over $150 \mathrm{~m}(500 \mathrm{ft})$ of Moreno Shale. While the distribution of these units is not well known in the basin, these units dip steeply basinward and persist to unknown depth.

A gross sandstone isopach map for the basin depicts an area of thicker sand development exceeding $490 \mathrm{~m}$ (1,600 ft) in the south central portion of the basin (Figure 13). Given the complex structural configuration of the basin, steep dips, and fault displacements along the basin margins, the isopach interval includes sandstones of the Cretaceous Panoche through Pliocene Orinda formations.

The Orinda Basin is a narrow linear basin measuring about $80 \mathrm{~km}(50 \mathrm{mi}$.) by $11 \mathrm{~km} \mathrm{(7} \mathrm{mi.)} \mathrm{and}$ is bounded on the west by the Hayward Fault and on the east by the Calaveras Fault. Its southern limit is the convergence of the two faults in northern Santa Clara County. Its northern end is taken to San Pablo Bay, past which the Sonoma Basin begins.

Limited well control and outcrop data indicates the Orinda Basin contains a sedimentary section very similar to that of the neighboring Livermore Basin. The deepest well bottomed at 3,048 $\mathrm{m}$ $(9,997 \mathrm{ft})$ in the abandoned one-well Pinole Point Field near the north end of the basin. Only two other wells exceeded 2,745 $\mathrm{m}(9,000 \mathrm{ft})$ with a handful going to $1,525-2,135 \mathrm{~m}(5,000-7,000 \mathrm{ft})$. The available well logs were used to construct a sandstone isopach map of logged section, which suggests a longitudinal thickness of at least $245 \mathrm{~m}(800 \mathrm{ft})$ extending from near the basin center to San Pablo Bay (Figure 13).

The Pinole Point Field produced only $2.2 \times 10^{3} \mathrm{~m}^{3}$ oil (14 MBO) oil and $3.14 \mathrm{Mm}^{3}(111 \mathrm{MMCF})$ gas from faulted and poorly developed Orinda Formation sandstones at $1,325 \mathrm{~m}(4,350 \mathrm{ft})$ and late Miocene Neroly sandstones at 1,950 m (6,400 ft). No petrophysical properties are reported for either reservoir zone.

The Sonoma Basin measures about $80 \mathrm{~km}(50 \mathrm{mi}$.) by $13 \mathrm{~km}(8 \mathrm{mi}$.) at its widest. The northerly extension of the Hayward Fault forms its western boundary. The Healdsburg and Rogers Creek faults mark its eastern limit. 
Deep subsurface well control is nonexistent in the Sonoma Basin and no depth to basement or sandstone isopach map could be prepared. Only five wells went to depths of more than $1,525 \mathrm{~m}$ $(5,000 \mathrm{ft})$. The deepest well, at the south end of the basin, bottomed at 2,471 $\mathrm{m}(8,105 \mathrm{ft})$ and encountered only $70 \mathrm{~m}(225 \mathrm{ft})$ of sandstone below $800 \mathrm{~m}$ (2,625 ft). In the other four wells, considerably less sand was encountered in the equivalent intervals.

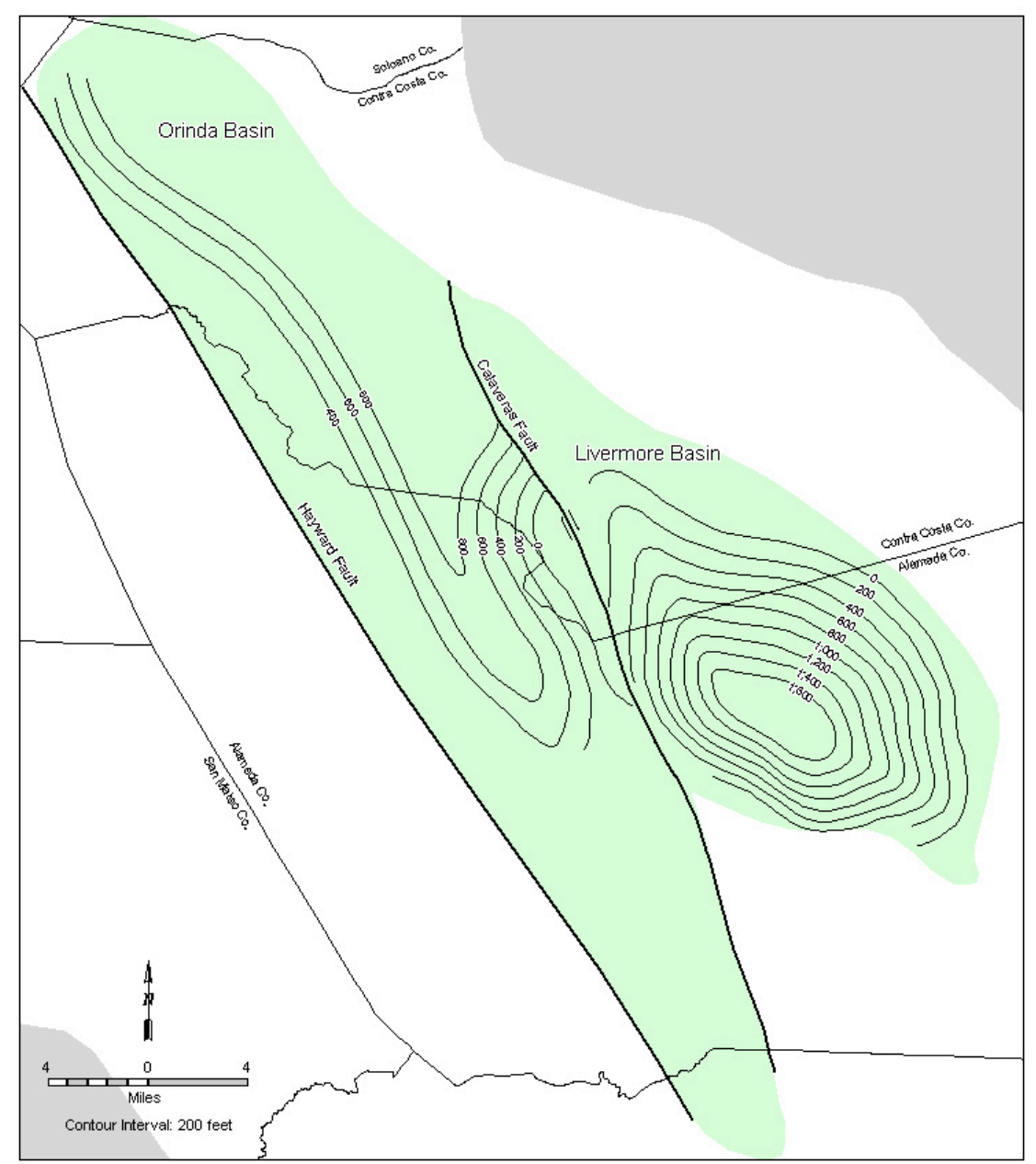

Figure 13. Livermore and Orinda basins - gross sandstone isopach map for depth interval $800-3,050 \mathrm{~m}(2,625-10,000 \mathrm{ft}$; or basement $)$.

Similarly, the only available petrophysical information about basin sandstones comes from sandstones in one of two shallow oil and gas pools that have been discovered. The Petaluma Field, in the south end of the basin, produced $2.2 \times 10^{3} \mathrm{~m}^{3}$ oil (14 MBO) and $37 \mathrm{Mm}^{3}(1.3 \mathrm{BCFG})$ from thin Pliocene Petaluma Formation sands at depths of only 185-380 m (600 to 1,240 ft) with reported porosities of 30 percent (DOG, 1983). The one well Cotati Gas Field, on the western fringe of the basin, produced only $17.2 \mathrm{Mm}^{3}$ (609 MMCF) gas from an unidentified Pliocene sand at $275 \mathrm{~m}(900 \mathrm{ft})$. No other data is available. 
Since the Sonoma Basin lacks sufficient well control to adequately assess its subsurface geology, its potential for geologic $\mathrm{CO}_{2}$ sequestration remains unknown. Its genetic relationship with the Livermore and Orinda basins implies that sandstones and shales equivalent to the MiocenePliocene section in the Livermore and Orinda basins may be present at depth and possibly be suitable for sequestration.

\subsubsection{Mojave Desert Province}

The Mojave Desert province is a broad interior region in southern California composed of isolated mountain ranges and intervening, fault bounded Cenozoic nonmarine basins with enclosed drainages and numerous playas. It is bounded on the north by the Garlock Fault, to the west by the San Andreas Fault, and to the east by the Colorado River.

Basement rocks exposed in adjacent mountain ranges consist of Proterozoic and Precambrian metamorphic and igneous rocks and limestones, and Mesozoic granitic rocks. Basin fill sediments are primarily nonmarine aggrading alluvial fan sequences derived from adjacent uplands, and interbedded layers of tuff, ash, lacustrine sediments, and evaporates. Volcanic flows and flow breccias are common with andesites and rhyolites characterizing the older extrusives and basaltic flows and cinder cones characterizing younger episodes (Norris and Webb, 1990).

Only six basins in the Mojave Desert province were determined to have $\mathrm{CO}_{2}$ sequestration potential, including the Bristol, Chuckwalla, Fremont, Palen, Palo Verde, and Ward basins. Aside from shallow water wells and mineral exploration borings, almost no subsurface stratigraphic information in the form of well control exists. Consequently, there are no means to currently assess the stratigraphic sequence for potential sandstone aquifers, sealing units, or trapping configurations. Hence, sandstone isopach maps could not be prepared for these basins. The basins were selected almost entirely on thickness of sedimentary fill derived from the geophysical depth-to-basement maps of Saltus and Jachens (1995) and Blakely and Ponce (2001). In the absence of basin specific data, it was assumed that the nature of sedimentary fill in Mojave Desert basins is ubiquitous and can be characterized by surface and shallow stratigraphic information. While it's relatively clear that these basins contain abundant sands and gravels, the presence of widespread seals and trapping mechanisms is less clear. However, surface and shallow basin center playa deposits, including mudstones and evaporate minerals, under appropriate structural and stratigraphic conditions, may provide localized seals if present at greater depths.

At current levels of knowledge, these basins appear to have considerably less sequestration potential than the larger, deeper, and better understood Cenozoic marine basins. More thorough subsurface characterization would be required before the sequestration potential of these basins could be properly assessed.

\subsubsection{Bristol Basin}

The Bristol basin covers approximately $1,013 \mathrm{~km}^{2}$ (391 sq. mi.) in south-central San Bernardino County. Gravity data indicates an area of approximately $220 \mathrm{~km}^{2}(85 \mathrm{sq}$. mi.) near the basin center where over $3,050 \mathrm{~m}(10,000 \mathrm{ft})$ sediments may overlie basement (Figure 14). While the 
nature of the deep beds is unknown, the dry lakebed is actively mined for the mineral halite (salt). The shallow beds include layers of sand, clay, and gypsum. Muds, largely of volcanic ash origin, are found within the salt body. The main salt body averages $2 \mathrm{~m}(5 \mathrm{ft})$ thick and is underlain by $2-3 \mathrm{~m}(8-10 \mathrm{ft})$ of lacustrine clay which is underlain by another salt bed approximately $2 \mathrm{~m}(5 \mathrm{ft})$ thick. Similar beds at depth could provide seals for deeper saline aquifers under the right structural or stratigraphic circumstances.

\subsubsection{Ward Basin}

Ward Basin is a narrow linear basin in southeastern San Bernardino County. It comprises approximately $1,564 \mathrm{~km}^{2}$ (604 sq. mi.). In the southern end of the basin, gravity data suggests an area of approximately $260 \mathrm{~km}^{2}$ (100 sq. mi.), which may contain over 1,525 m (5,000 ft) of sedimentary fill (Figure 14).

\subsubsection{Palen Basin}

Palen Basin is a small basin of about $381 \mathrm{~km}^{2}$ (147 sq. mi.) in eastern Riverside County. Gravity data indicates a small depression in the southern end of the basin comprising only $60 \mathrm{~km}^{2}(23 \mathrm{sq}$. mi.) in which sediments may reach close to $1,525 \mathrm{~m}(5,000 \mathrm{ft})$ (Figure 14).

\subsubsection{Chuckwalla Basin}

Chuckwalla Basin covers about 1,380 km² (533 sq. mi.) in eastern Riverside County. Gravity data suggests that two small sub-basins, which collectively comprise an area of about $236 \mathrm{~km}^{2}$ (91 sq. mi.), and may contain sediments up to $1,830 \mathrm{~m}$ (6,000 ft) thick (Figure 14). No subsurface stratigraphic information is available.

\subsubsection{Palo Verde Basin}

Palo Verde Basin straddles the California - Arizona state line in eastern Riverside County, California and La Paz County, Arizona. The California portion includes approximately 1,062 $\mathrm{km}^{2}$ (410 sq. mi.), of which about $400 \mathrm{~km}^{2}$ (155 sq. mi.) may be filled with sediments greater than $800 \mathrm{~m}(2,625 \mathrm{ft})$ thick (Figure 14). Two smaller subbasins over 1,525 $\mathrm{m}(5,000 \mathrm{ft})$ deep are indicated in the north and south ends of the basin. 


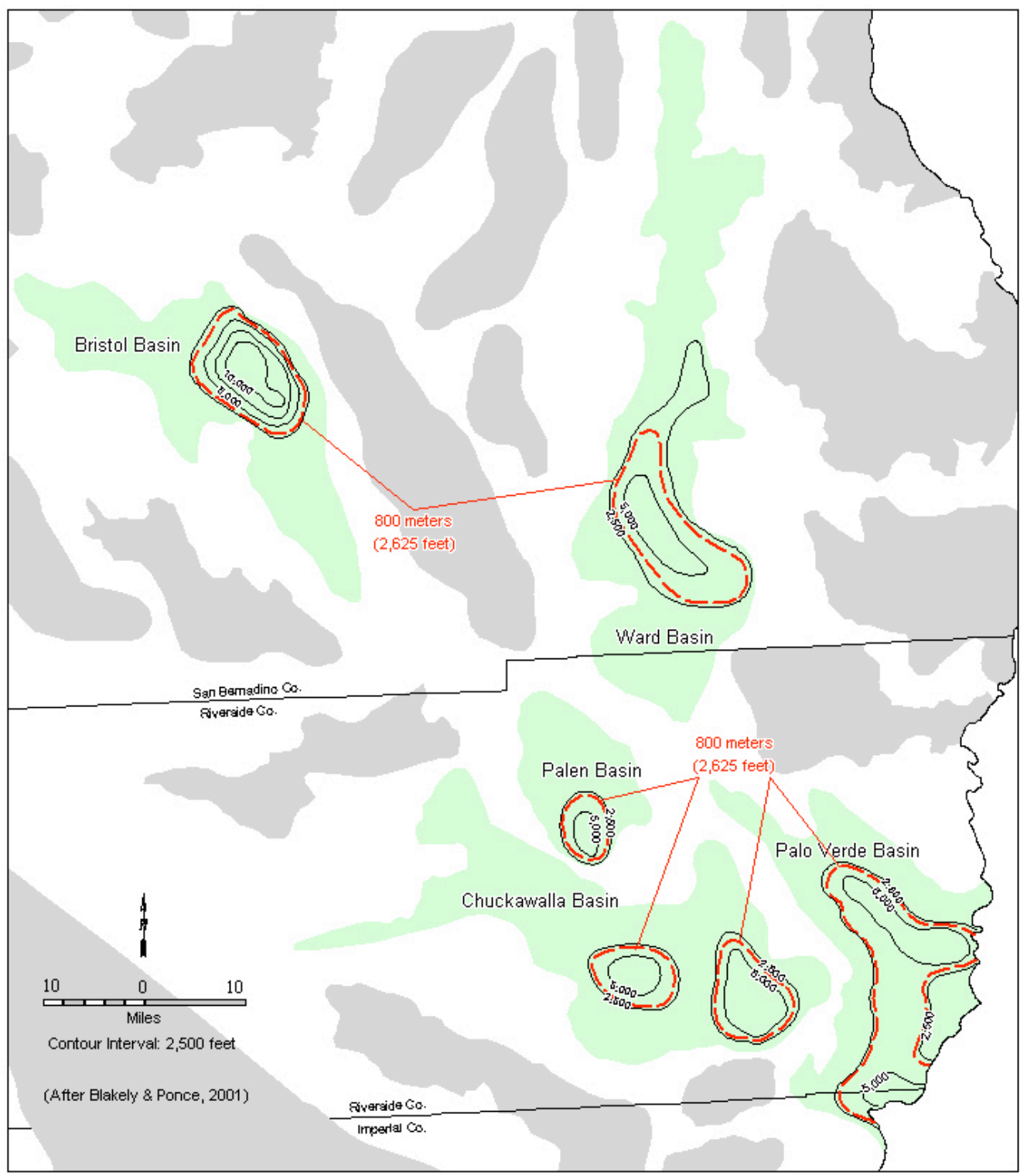

Figure 14. Bristol, Ward, Palen, Chuckwalla, and Palo Verde basins depth-to-basement map.

\subsubsection{Fremont Basin}

The northern end of the Fremont Valley, in eastern Kern County, is underlain by a small narrow basin of about $325 \mathrm{~km}^{2}$ (125 sq. mi.) containing some of the thickest known sedimentary fill in the Mojave Desert. The basin is genetically related to the Garlock Fault zone, which forms its northern boundary. Gravity interpretations reveal an area of about $135 \mathrm{~km}^{2}$ (52 sq. mi.), which may contain sediments over 3,660 $\mathrm{m}(12,000 \mathrm{ft})$ thick along the basin axis (Figure 15). An exploratory well drilled in 1926 to a depth of $1,545 \mathrm{~m}(5,063 \mathrm{ft})$ encountered interbedded sand, gravel, and clay from surface to total depth. Deeper sediments are likely to be similar with the 
possibility of Miocene marine rocks at depth. While this basin may contain saline aquifers with carbon sequestration potential, its proximity to the Garlock Fault may influence that potential.

\subsubsection{Basin and Range Province}

The Basin and Range province encompasses the westernmost part of the Great Basin which lies largely in neighboring Nevada. The California portion is bounded on the west by the Sierra Nevada Mountains and to the south by the Garlock Fault. It includes most of Inyo and Mono counties, northeastern Kern County, and northern San Bernardino County. A small portion of the Basin and Range extends northward through eastern Lassen and Modoc counties into southeastern Oregon. Bordering the Basin and Range to the west in Lassen and Modoc Counties is the Modoc Plateau province.

The Basin and Range is characterized by north-northwesterly trending fault bounded uplifts and intervening downdropped grabens produced by Cenozoic crustal extension and transform motion. Most basins exhibit interior drainages with ephemeral saline lakes and playas. Of the many basins identified, only seven appear to have sufficient depth and sedimentary fill for potential $\mathrm{CO}_{2}$ sequestration. These include the Amargosa, Pahrump, Mesquite, and Owens basins in the southern Basin and Range, and the Surprise, Goose Lake, and Alturas basins in the northern Basin and Range.

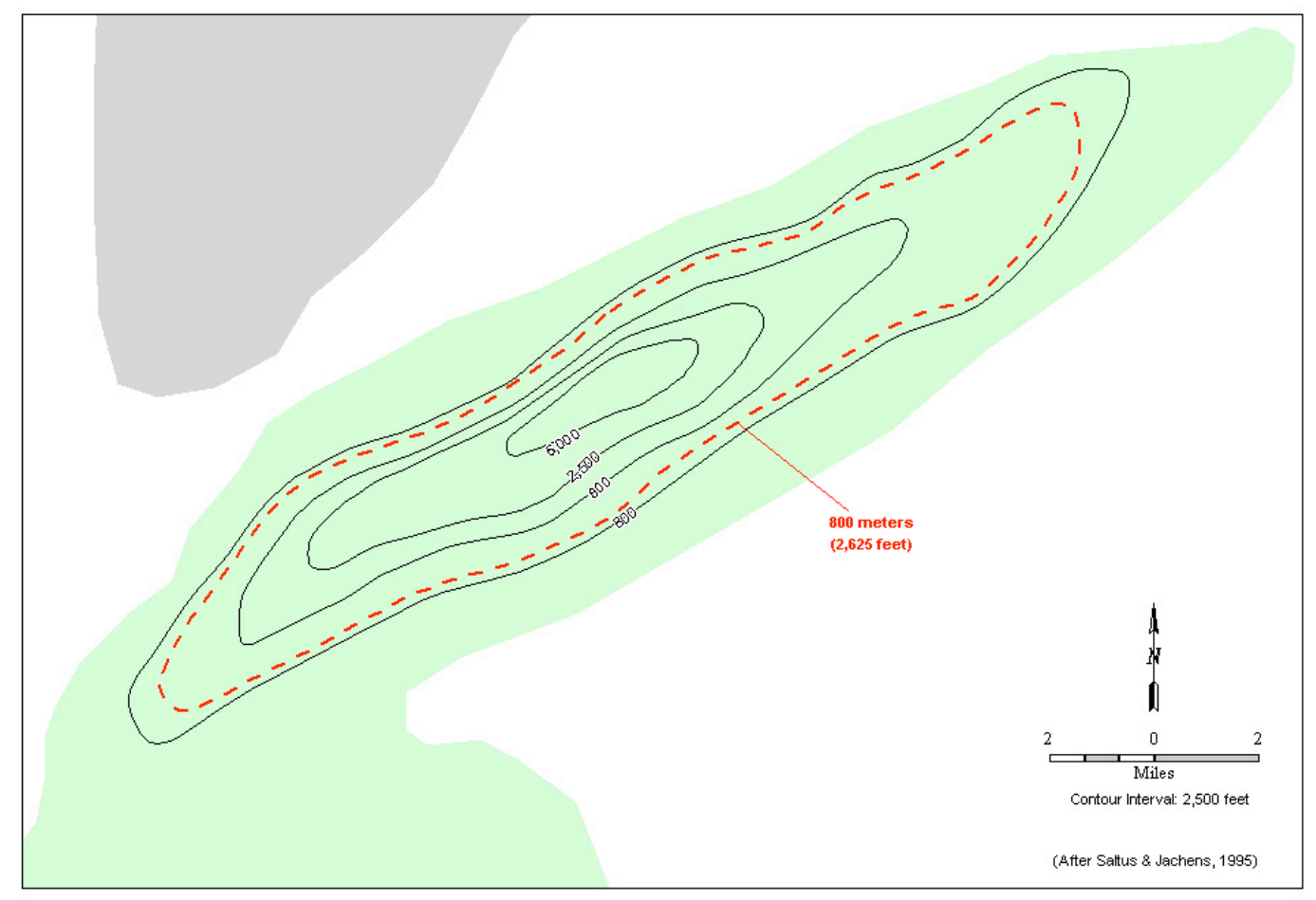

Figure 15. Fremont Basin - depth-to-basement map. 
Similar to the Mojave Desert, very little well control exists to evaluate subsurface stratigraphy in the southern part of the province and the depth-to-basement maps of Saltus and Jachens (1995) and Blakely and Ponce (2001) were again used as the primary tool for assessing sediment thickness. In the northern Basin and Range, no geophysical mapping was available. However, the stratigraphy in several geothermal exploratory wells between $1,508 \mathrm{~m}(4,946 \mathrm{ft})$ and $2,136 \mathrm{~m}$ $(7,005 \mathrm{ft})$ deep in the Surprise Basin was assumed to be similar to that in the neighboring Goose Lake and Alturas basins.

Generally, the basins of the Basin and Range province contain only thin sections of Miocene to Holocene terrestrial sediments and Pliocene to Holocene volcanic rocks. Basin fill tends to be largely coarse alluvial fan material and colluvium shed from bordering uplifts in thick flanking fans and wedges, and possessing no updip stratigraphic seal. Marine sedimentation is absent. Similar to the Mojave Desert, some basins contain Pleistocene lacustrine claystone, mudstone, and evaporate beds which may provide seals for saline aquifers under favorable structural or stratigraphic conditions. For example, in the Searles Valley, where shallow evaporites are solution mined, saline deposits are known to range from 11-24 m (35-80 ft) thick.

\subsubsection{Amargosa Basin}

The Amargosa Basin is one of three northwest trending basins straddling the California - Nevada state line that may contain sufficient sedimentary fill for carbon sequestration. The California portion of the basin, in southeast Inyo County, comprises approximately $710 \mathrm{~km}^{2}(275 \mathrm{sq}$. mi.), of which approximately $155 \mathrm{~km}^{2}$ (60 sq. mi.) contain sediments greater than $760 \mathrm{~m}(2,500 \mathrm{ft})$ thick (Figure 16). Sediment thickness may reach as much as $1,525 \mathrm{~m}(5,000 \mathrm{ft})$ in the west side of the basin.

\subsubsection{Pahrump Basin}

Pahrump Basin straddles the state line about 13-16 km (8-10 mi.) southeast of the Amargosa Basin in Inyo County. About $342 \mathrm{~km}^{2}$ (132 sq. mi.) lies within California with approximately $130 \mathrm{~km}^{2}$ (50 sq. mi.) underlain by sediments thicker than $760 \mathrm{~m}$ (2,500 ft) (Figure 16). Maximum indicated fill is estimated to exceed 2,285 $\mathrm{m}(7,500 \mathrm{ft})$ near the state line.

\subsubsection{Mesquite Basin}

A few kilometers south of the Pahrump Basin is the Mesquite Basin in northeast San Bernardino and northeasternmost Inyo counties. The California portion covers $319 \mathrm{~km}^{2}(123 \mathrm{sq}$. mi.) of which about $70 \mathrm{~km}^{2}$ (27 sq. mi.) contains fill estimated to be between 760-2,285 m (2,500-7,500 ft) thick (Figure 16). 


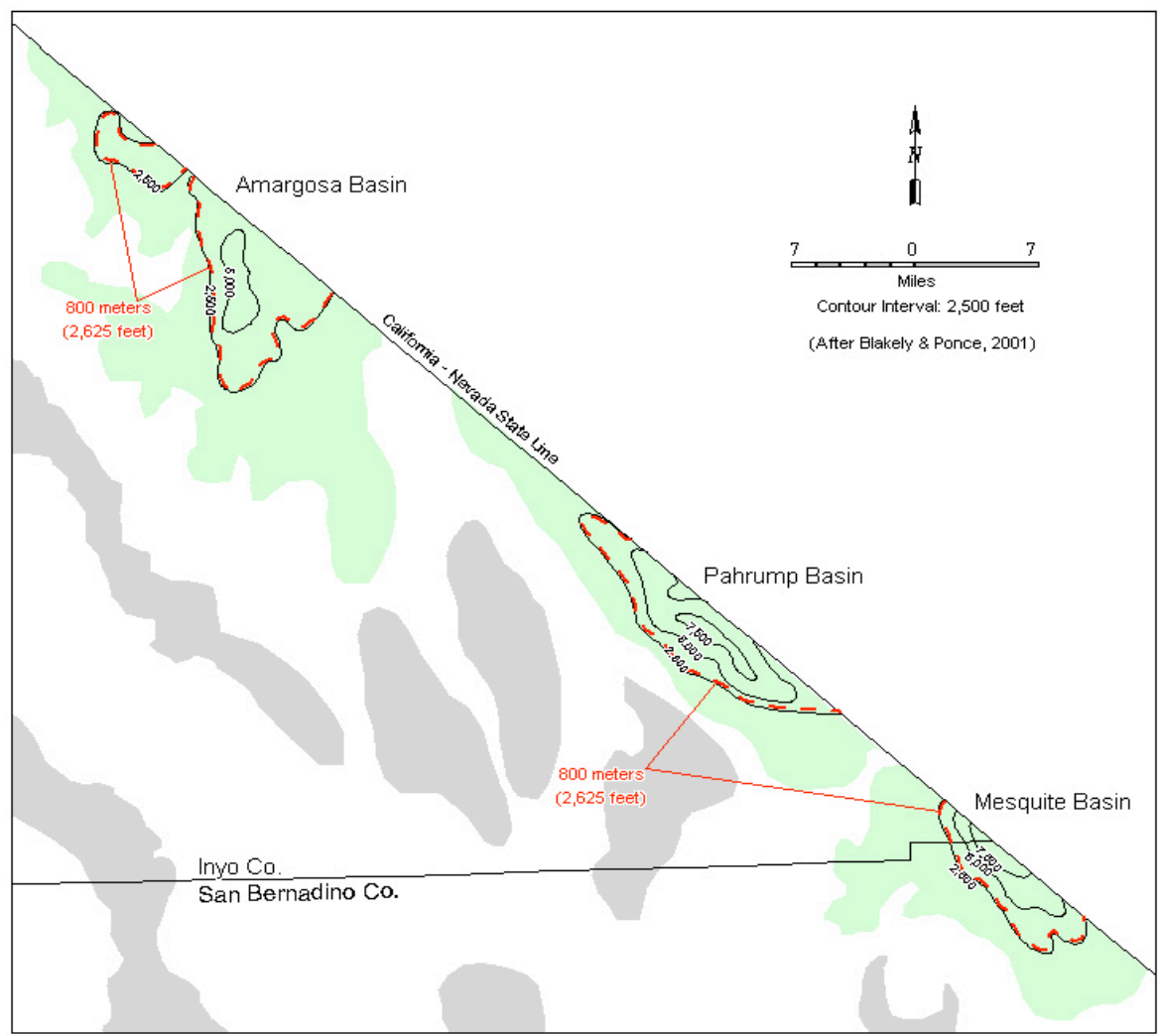

Figure 16. Amargosa, Pahrump, and Mesquite basins - depth-to-basement map.

\subsubsection{Owens Basin}

The Owens basin is the deepest and largest of the identified basins in the Basin and Range province with sequestration potential. A narrow, linear fault bounded graben, it extends from southwestern Inyo County for approximately $225 \mathrm{~km}$ (140 mi.) northward through Mono County to the Nevada state line, and ranges in width from as little as $3 \mathrm{~km}(2 \mathrm{mi}$.) to over $16 \mathrm{~km}$ (10 mi.) at Owens Dry Lake. It lies along the western edge of the Basin and Range geomorphic province, within the Eastern California Shear Zone, where it forms part of the boundary between the Sierra Nevada and Basin and Range provinces. Steeply dipping faults of the Owens Valley and WhiteInyo Mountain fault systems separate it from the Sierra Nevada Mountains to the west and the Inyo and White Mountains to the east respectively.

The shallowest sediments consist of unconsolidated Quaternary alluvial fan material deposited along the basin margin which grade into nearshore fluvial and lacustrine sand, silt, clay, and evaporites near the southern basin center. These surficial deposits reach at least $365 \mathrm{~m}(1,200 \mathrm{ft})$ thick. In some areas, these strata are interbedded with basalt flows or shallow unconsolidated pumice beds. The only deep control consists of a 2,131 m (6,989 foot) exploratory well drilled on the Owens Lake bed. This well encountered Pliocene to Holocene interbedded muds, clays, sands, and evaporites. 
No wells have been drilled to basement, but gravity data indicates two areas of thick basin sediments. The larger of the two, about $20 \mathrm{~km}$ (12 mi.) south of Lone Pine and underlying Owens Lake, may contain up to 4,575 $\mathrm{m}(15,000 \mathrm{ft})$ of sediments (Figure 17). The smaller of the two lies southeast of Bishop and extends from Big Pine to the Mono County line. It may contain as much as $3,050 \mathrm{~m}(10,000 \mathrm{ft})$ of fill.

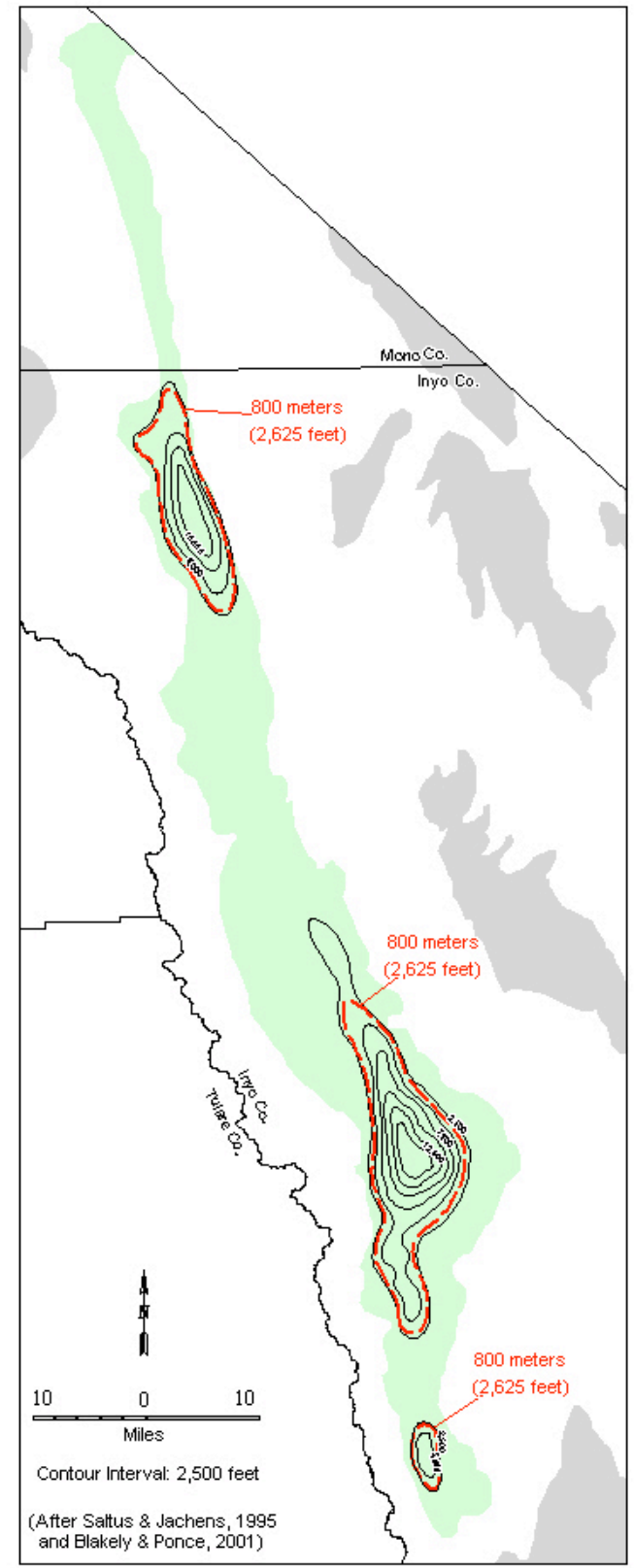

Figure 17. Owens Basin - depth-to-basement map.

The Owens basin is geologically active, which must be taken into consideration. As much as 20 -25 percent of the relative motion between the Pacific and North American plates is 
accommodated within the Eastern California Shear Zone, with a significant amount of this along the Owens Valley Fault-White Mountains Fault system (Schroeder et al., 2002). Significant tectonic events along the Owens Valley Fault include the pre-1872, 7.4 magnitude earthquake. Offsets of the Owens Valley Fault indicate at least 2 additional large earthquakes occurred

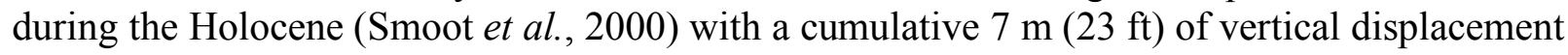
and $5 \mathrm{~m}$ (16 ft) of horizontal displacement (Sheehan, 1987).

\subsubsection{Surprise Basin}

Surprise Basin is a large complexly faulted graben straddling the Nevada state line in northeast California's Modoc County. The basin is approximately $80 \mathrm{~km}$ (50 mi.) long by $20 \mathrm{~km}$ (12 mi.) wide, the California portion comprising about $857 \mathrm{~km}^{2}$ (331 sq. mi.). The valley is bounded on all sides by normal faults including the Surprise Valley Fault on the west and the Hays Canyon Fault on the east. Smaller faults mark its northern and southern ends. Surface deposits are coalesced alluvial fan and nearshore lake deposits. While the depth to bedrock is unknown, several geothermal exploratory wells penetrated a 2,139 m (7,015 foot) thick sequence of interbedded volcanic breccias, tuffs, volcanic sandstones and conglomerates, clays, rhyolite, andesite, and basalt. Sample logs and lost circulation problems while drilling suggest that the igneous rocks may be highly fractured, but lacustrine clay beds and altered argillaceous tuffs might provide seals for underlying sandstones where structural closure or stratigraphic containment could be demonstrated.

\subsubsection{Goose Lake Basin}

Goose Lake Basin is approximately $24 \mathrm{~km}$ (15 mi.) northwest of and sub-parallel to Surprise Basin in northern Modoc County. The basin overlaps the Oregon state line to the north. The California portion is approximately $40 \mathrm{~km}$ (24 mi.) long by $16 \mathrm{~km}$ (10 mi.) wide, comprising approximately $458 \mathrm{~km}^{2}$ (177 sq. mi.). Similar to Surprise Valley, it consists of a graben bounded by numerous normal faults. Surface deposits consist of alluvium and lake deposits grading laterally into marginal alluvial fans. Basin depth is unknown but its proximity to, and similar structural framework with Surprise Basin suggests it too may contain a thick sequence of interbedded sands, conglomerates, volcanics, and clays.

\subsubsection{Alturas Basin}

The Alturas Basin is located west of Surprise Basin and south of Goose Lake Basin in eastern Modoc County. It occupies an area of $298 \mathrm{~km}^{2}$ (115 sq. mi.) and is bounded to the east by the Warner Mountains and to the south and west by the Likely Fault and volcanic tablelands. Geologically, the basin is similar to the neighboring Surprise and Goose Lake basins and thought to host an unknown thickness of interbedded sands, conglomerates, volcanics, and clays. Depth to basement is unknown. Lacking data to the contrary, the basin was retained as a potential candidate for $\mathrm{CO}_{2}$ sequestration. 


\subsubsection{Modoc Plateau Province}

The Modoc Plateau province is a transitional zone between the Cascades, Basin and Range, and Sierra Nevada provinces. It is an undulating plateau composed mostly of Miocene to Holocene basaltic flows. Unlike many of the basins of the Mojave Desert and Basin and Range, little gravity data was available to determine basin depth. Further, deep well control is virtually absent. Published geological information on the basins is also meager. Of the four basins originally identified in the province, only the Big Valley and Fall River basins have indications of sequestration potential.

\subsubsection{Big Valley Basin}

Big Valley Basin is a broad flat plain comprising about $319 \mathrm{~km}^{2}$ (123 sq. mi.) in southwest Modoc and northwestern Lassen Counties. The basin consists of a series of downthrown grabens surrounded by tilted fault block ridges. To the north, south, ands east are Pleistocene and Pliocene basalt and Tertiary pyroclastic rocks of the Turner Creek Formation, and to the west are Tertiary rocks of the Big Valley Mountain volcanic series.

Basin depth is unknown, but a single geothermal exploratory well drilled near the basin center provides some insight into the basin's stratigraphy. The well encountered 2,134 $\mathrm{m}(7,000 \mathrm{ft}) \mathrm{of}$ interbedded medium to coarse arkosic and volcanic sandstone and conglomerate interbedded with tuffaceous claystone, green-gray claystone, tuff, and siltstone. The lateral extent of these facies is unknown, but the vertical facies relationships suggest that at least aquifers and seals may be present.

\subsubsection{Fall River Basin}

Fall River Basin encompasses about $194 \mathrm{~km}^{2}$ (75 sq. mi.) in northeast Shasta County, about 25 $\mathrm{km}$ (15 mi.) southwest of the Big Valley Basin. No deep wells have been drilled to determine basin fill. However, a single exploratory well encountered at about $282 \mathrm{~m}(925 \mathrm{ft})$ of diverse shallow sediments. Deposits include Holocene alluvium and stream channel and floodplain sands, Pleistocene and Holocene volcanic cinders, tuffs, and basalts, and Pleistocene near shore lacustrine clayey silt and sand. The proximity and geologic similarity to the Big Valley Basin suggests the basin may contain over $1,000 \mathrm{~m}$ (several thousand feet) of interbedded sandstones and potential seals.

\subsubsection{Colorado Desert Province}

\subsubsection{Salton Trough}

The Salton Trough is a northeast-southwest elongate Neogene structural trough underlying the Coachella and Imperial Valleys. Its surface expression comprises the Colorado Desert geomorphic province. It extends from the vicinity of Palm Springs in Riverside County, southeastward through Imperial County into Mexico. The US portion of the basin is about 200 $\mathrm{km}$ (125 mi.) long by 13-105 km (8-65 mi.) wide. It is bordered on the east by the San Andreas 
Fault and uplifted crystalline rocks of the Little San Bernardino and Chocolate Mountain ranges, and on the west by the San Jacinto Mountains and the southern Peninsular Ranges.

The Salton Trough differs from California's other large Cenozoic sedimentary basins in several respects that may adversely impact its potential for geologic $\mathrm{CO}_{2}$ sequestration. However, its considerable areal extent and depth, in conjunction insufficient existing well control, requires that additional information be obtained before the basin, in whole or in part, is excluded from consideration as a potential sequestration site.

Tectonically, the Salton Trough is one of California's most active basins. It is the northward extension of the Gulf of California, an active rift zone where new crust is being formed by intrusion of mafic igneous rocks at depth. Rifting and magmatic intrusion produces a high heat flow, which has metamorphosed part of the sedimentary section (Fuis et al., 1984). The unusually high geothermal gradients are also responsible for the basin's geothermal energy fields. High temperature water and steam has been harnessed from shallow reservoirs in five geothermal fields ranging from the Salton Sea Geothermal Field at the south end of the Salton Sea to the Heber Geothermal Field near the Mexican Border.

Natural magmatic offgasing has also resulted in shallow high purity $\mathrm{CO}_{2}$ reservoirs. Lenticular sandstones at depths of less than $300 \mathrm{~m}$ (1,000 ft) were commercially exploited during the early to mid-1900s in the now abandoned Imperial Carbon Dioxide Gas Field at the south end of the Salton Sea.

The Salton Trough is filled with a thick sequence of Miocene-Pliocene sedimentary deposits, reaching a thickness of over 5,488 $\mathrm{m}(18,000 \mathrm{ft})$ near the Mexican border (Figure 18). In contrast to California's other large Cenozoic marine basins, the Salton Trough is filled largely, if not entirely, with nonmarine sediments. Consequently, no oil or gas production has been established in the basin and deep well control is scarce. While marine sandstones and shales of the Imperial Formation have been identified in bordering outcrops (Dibblee, 1954), the few deep wells encountered only nonmarine rocks, bottoming in terrestrial and lacustrine sediments of the overlying Borrego Formation at depths of over 4,268 m (14,000 ft). Underlying Imperial Formation marine deposits, if present, would likely be metamorphosed in the deep basin, but as yet unidentified marine rocks may occur at shallower depths along the basin margins. Nonetheless, gross sandstone thickness exceeds $1,220 \mathrm{~m}(4,000 \mathrm{ft})$ near the basin axis (Figure 19). Like the terrestrial basins of the Mojave Desert and Basin and Range, the prevalence of nonmarine clastic deposits, combined with the lack of widespread marine shales, reduces the basin's potential for large-scale geologic sequestration. 


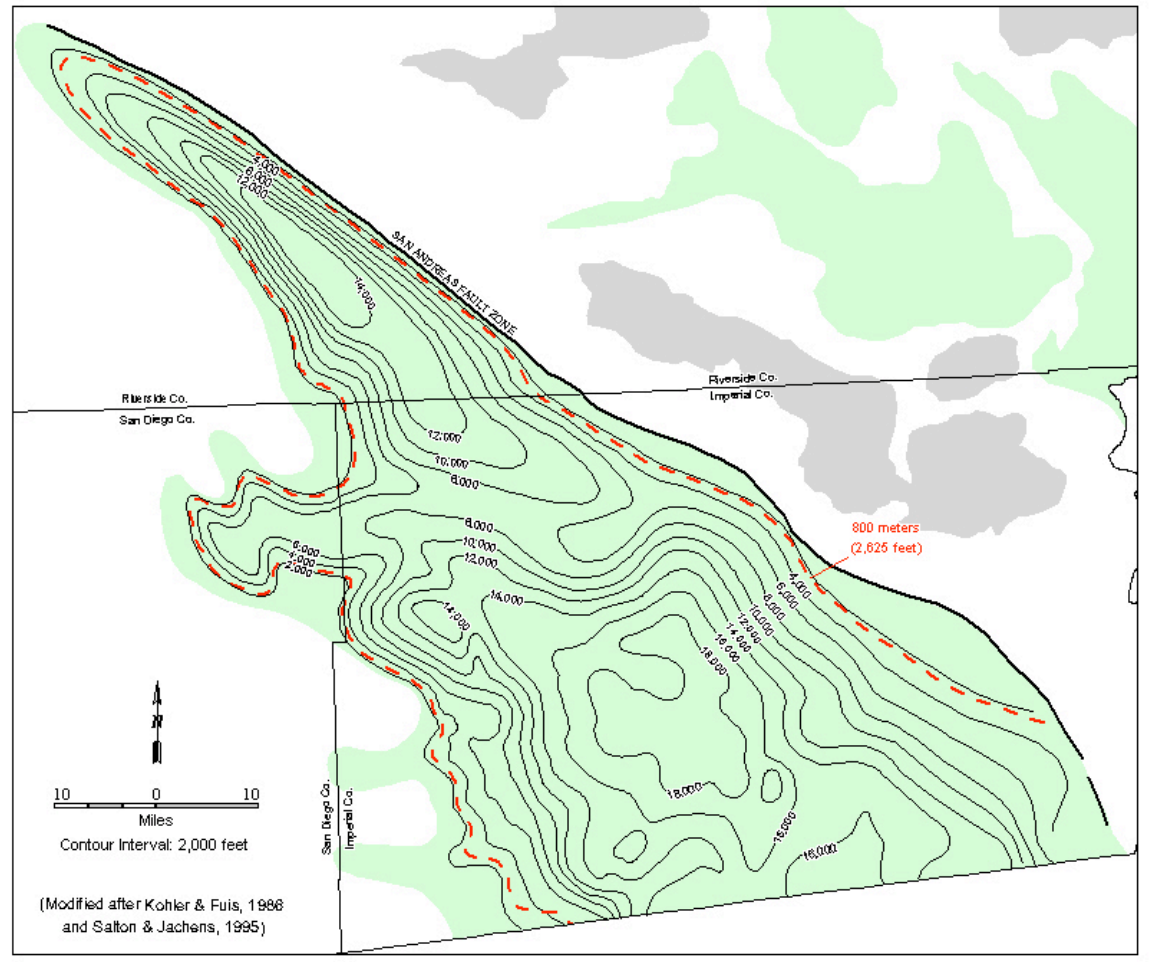

Figure 18. Salton Trough - depth-to-basement map.

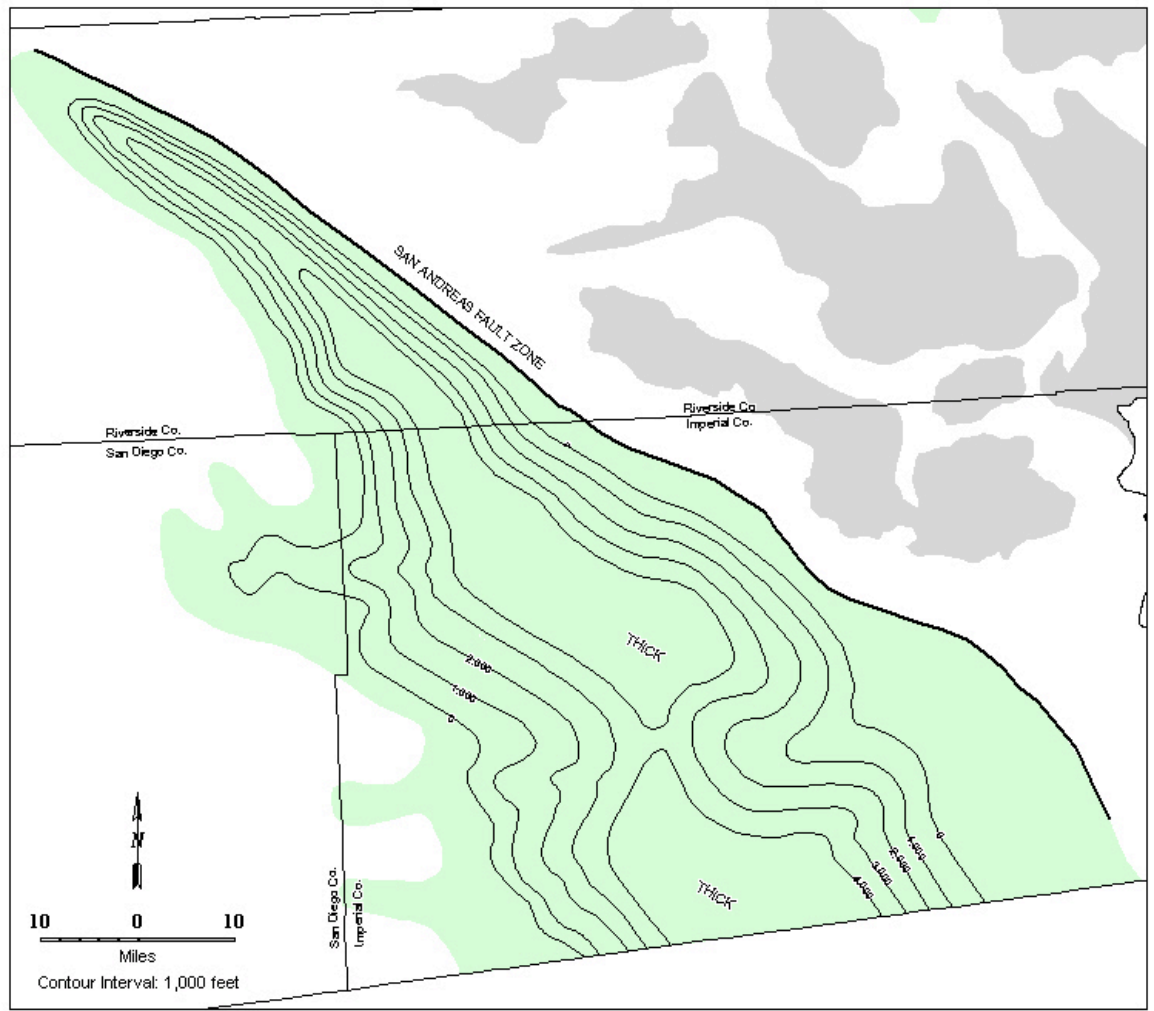

Figure 19. Salton Trough - gross sandstone isopach map for depth interval 800-3,050 m (2,625-10,000 ft; or basement). 


\section{Conclusions}

A preliminary screening of California's sedimentary basins indicates that at least 27 basins possess varying potential for $\mathrm{CO}_{2}$ sequestration. These basins comprise an aggregate area of more than $98,420 \mathrm{~km}^{2}$ (38,000 sq. mi.) and range from small, relatively shallow terrestrial basins in the Mojave Desert and Basin and Range geoprovinces to the much larger and deeper Cenozoic marine basins of coastal and central California.

While these basins all appear to meet minimum depth and stratigraphic requirements for $\mathrm{CO}_{2}$ injection, our current understanding of each basin's suitability is dictated by the amount of available subsurface geological information. Since marine basins tend to be hydrocarbon rich, exploration and development of these resources has provided abundant geological, petrophysical, and fluid data allowing a more objective assessment of a basin's $\mathrm{CO}_{2}$ sequestration potential. Similar data is nearly, if not completely, absent in California's terrestrial basins where, in some cases, data is limited to geophysical interpretations of depth-to-basement. California's marine sedimentary basins include thick sequences of laterally extensive marine sandstones and shales providing multiple potential sequestration objectives and thick widespread seals. Depths range from shallow to well over 3,050 m (10,000 ft). Additionally, marine basins not only provide opportunities for sequestration in saline aquifers, but also include numerous, well characterized, abandoned and mature oil and gas reservoirs that may provide near-term and future targets for $\mathrm{CO}_{2}$ sequestration.

Currently, the most promising basins for potential $\mathrm{CO}_{2}$ sequestration include the San Joaquin, Sacramento, Ventura, Los Angeles, and Eel River basins. Smaller marine basins such as the Salinas, La Honda, Cuyama, Livermore, Orinda, and Sonoma basins are also promising but more restricted in terms of size and available geological information. Several terrestrial basins, including the large Salton Trough, may present some opportunities for $\mathrm{CO}_{2}$ sequestration and cannot be excluded from consideration given the limited currently available information.

Geological information resulting from this assessment will be used by WESTCARB participants to help identify potential areas for $\mathrm{CO}_{2}$ sequestration, and to assess $\mathrm{CO}_{2}$ storage capacity of saline aquifers and hydrocarbon reservoirs in California. Preliminary estimates of $\mathrm{CO}_{2}$ storage capacity of the ten largest basins identified in this assessment have placed the storage capacity of saline aquifers between 146-840 Gt $\mathrm{CO}_{2}$ depending on the varying degrees of dissolved phase and separate-phase pore volume storage (Myer et al., 2005). Additional geological information and characterization of these basins, including detailed, formation specific, mapping will be required before their specific potential for $\mathrm{CO}_{2}$ sequestration can be more accurately assessed. 


\section{References}

Adam, D.P., Rieck, H.J., McGann, M.L., Schiller, K.H., Sarna-Wojcicki, A.M., Roberts, A.P., 1994, Lithologic description of a sediment core from Butte Valley, Siskiyou County, California: U.S. Geological Survey Open-File Report OF 94-0593, 84 p.

Bailey, T.L., 1954, Geology of the western Ventura Basin, Santa Barbara, Ventura, and Los Angeles Counties, Map Sheet No. 4, in Geology of Southern California; Jahns, R.H., ed.: California Division of Mines Bulletin 170.

Baldwin, T.A., 1950, San Ardo; a stratigraphic analysis of a California oil field: Bulletin of the American Association of Petroleum Geologists, 34; 10, p. 1981-1989.

Bartow, J. A., and McDougall, K., 1984, Tertiary stratigraphy of the southeastern San Joaquin Valley, California: U.S. Geological Survey Bulletin 1529-J, 43 p.

Bartow, J.A., and Nilsen, T.H., 1990, Review of the Great Valley sequence, eastern Diablo Range and northern San Joaquin Valley, central California, in Structure, stratigraphy and hydrocarbon occurrences of the San Joaquin Basin, California; Kuespert, J.G. and Reid, S.A., eds.: Field Trip Guidebook 64-Pacific Section, Society of Economic Paleontologists and Mineralogists, p. 253-265.

Biddle, K.T., 1991, The Los Angeles Basin: an overview, in Active margin basins, Biddle, K.T., ed.: American Association of Petroleum Geologists Memoir 52, p. 5-24.

Blake, G.H., 1991, Review of the Neogene biostratigraphy and stratigraphy of the Los Angeles Basin and implications for basin evolution, in Active margin basins; Biddle, K.T., ed.: American Association of Petroleum Geologists Memoir 52, p. 135-184.

Blakely, R.J., and Ponce, D.A., 2001, Map showing depth to pre-Cenozoic basement in the Death Valley ground-water model area, Nevada and California: U.S. Geological Survey Miscellaneous Field Studies Map MF-2381-E, 6 p., 1 sheet.

California Department of Conservation, Division of Oil and Gas (DOG), 1983, California oil \& gas fields, volume 3, northern California: California Dept. of Conservation, Division of Oil and Gas, publication TR10.

California Department of Conservation, Division of Oil, Gas, and Geothermal Resources (DOGGR), 1998, California oil \& gas fields, volume 1, central California: California Dept. of Conservation, Division of Oil and Gas, publication TR11.

California Department of Conservation, Division of Oil, Gas, and Geothermal Resources (DOGGR), 1991, California oil \& gas fields, volume 2, southern, central coastal, and offshore California: California Dept. of Conservation, Division of Oil and Gas, publication TR12.

Callaway, D.C., 1964, Distribution of uppermost cretaceous sands in the Sacramento-northern San Joaquin Basins of California, Selected Papers: San Joaquin Geological Society, 2, p. 4-18. 
Callaway, D.C., 1990, Organization of stratigraphic nomenclature for the San Joaquin Basin, California, in Structure, stratigraphy and hydrocarbon occurrences of the San Joaquin Basin, California; Kuespert, J.G., and Reid, S.A., eds.: Field Trip Guidebook 64-Pacific Section, Society of Economic Paleontologists and Mineralogists, p. 5-21.

Cherven, V.B., 1983, Stratigraphy, facies, and depositional provinces of the middle Eocene Domengene Formation, southern Sacramento Basin, in Cenozoic marine sedimentation; Pacific margin, U.S.A.; Larue, D.K., and Steel, R.J., eds.: Society of Economic Paleontologists and Mineralogists, Pacific section, p. 63-75.

Chesterman, C.W. and Saucedo, G.W., 1984, Cenozoic volcanic stratigraphy of Shasta Valley: California Division of Mines and Geology, California Geology 37(4), p. 67-74

Church, H.V., 1963, King City Oil Field, Monterey County, California, in Geology of Salinas Valley and the San Andreas fault: American Association of Petroleum Geologists and Society of Economic Paleontologists and Mineralogists, 1963 Spring Field Trip Guidebook, p. 60-71.

Clarke, S.H., Jr., 1987, Late Cenozoic geology and structure of the onshore-offshore Eel River Basin, northern California, in Tectonics, sedimentation, and evolution of the Eel River and associated coastal basins of northern California; Schymiczek, H., and Suchsland, R., eds.: Bakersfield, San Joaquin Geological Society Miscellaneous Publication 37, p. 31-39.

Colvin, R.G., 1963, San Ardo Field, Monterey County, California, in Geology of Salinas Valley and the San Andreas fault: American Assocciation of Petroleum Geologists and Society of Economic Paleontologists and Mineralogists, 1963 Spring Field Trip Guidebook, p. 57-59.

Crouch, K.C. and Bachman, B.B., 1987, Exploration potential, offshore Point Arena and Eel River basins, in Tectonics, sedimentation, and evolution of the Eel River and associated coastal basins of northern California; Schymiczek, H., and Suchsland, R., eds.: Bakersfield, San Joaquin Geological Society Miscellaneous Publication 37, p. 99-111.

Darrow, R., 1979, The Livermore basin, in Geology and Engineering in the Livermore-Hayward region, California: Northern California Geological Society, field trip guidebook, $11 \mathrm{p}$.

Department of Water Resources, 2003, California's groundwater: California Department of Water Resources Bulletin 118, 246 p.

Dibblee, T.W., Jr., 1954, Geology of the Imperial Valley region, in Geology of Southern California; Jahns, R.H., ed.: California Division of Mines Bulletin, 170, p. 21-28.

Eilperin, J., 2005, Scientists looking at ways to trap greenhouse gases: Washington Post, Tuesday, February 22, 2005, p. A02.

Fuis, G.S., and Kohler, W.M., 1984, Crustal structure and tectonics of the Imperial Valley region, California, in The Imperial Basin - tectonics, sedimentation, and thermal aspects; 
Rigsby, CA., ed.: Field Trip Guidebook 40-Pacific Section, Society of Economic Paleontologists and Mineralogists, p. 1-13.

Garcia, R., 1981, Depositional systems and their relation to gas accumulation in Sacramento Valley, California: American Association of Petroleum Geologists Bulletin 65(4), p. 653-673.

Goff, G., and Lackner, K.S., 1998, Carbon dioxide sequestering using ultramafic rocks: Environmental Geosciences, 5(3), p. 1-13.

Handman, E.H., Londquist, C.J., and Maurer, D.K., 1990, Ground-water resources of Honey Lake valley, Lassen County, California, and Washoe County, Nevada: U.S. Geological Survey Water Resources Investigation WRI 90-4050, 128 p.

Hansen, J., 2004, Defusing the global warming time bomb: Scientific American, 297(5579), p. 69-77.

Hansen, L.D., and Dipple, G.M., 2005, Carbonated serpentinite (listwanite) at Atlin, British Columbia — a geological analogue to carbon dioxide sequestration: Canadian Mineralogist, 43, p. 225-239.

Hovorka, S.D., Romero, M.L., Warne, A.G., Ambrose, W.A., Tremblay, T.A., Trevino, R.H., and Sasson, D, 2003, Sequestration of greenhouse gases in brine formations: University of Texas, Bureau of Economic Geology. Available electronically at: http://www.beg.utexas.edu/environqlty/co2seq/dispslsaln.htm.

Henry, M.J., 1987, Los Angeles Basin-an overview, in Oil-producing areas in Long Beach; Clarke, D., and Henderson, C., eds.: American Association of Petroleum Geologists Field trip Guidebook, Pacific Section, p. 1-29.

Herzog, H.J. and D. Golomb, 2004, Carbon capture and storage from fossil fuel use, in Encyclopedia of Energy; Cleveland, C.J., ed.: Elsevier Science Inc., New York, p 277-287.

Hopps, T.E., and Horan, E.P., 1983, Subsurface stratigraphy: Eel River Basin, Humboldt County, California, in Selected papers of the Pacific Section 1983 annual meeting, Sacramento, California, Hester, R.L., and Hallinger, D.E., eds.: Los Angeles, Pacific Section, American Association of Petroleum Geologists, p. 1-29.

Imperato, D.P, Nilsen, T.H., and Moore, D.W., 1990, Depositional facies of the upper Cretaceous Forbes Formation, Sacramento Basin, California: American Association of Petroleum Geologists Bulletin, 74(5), 681 p.

Jennings, C.W., Strand, R.G., and Rogers, T.H., 1977, Geologic map of California: California Division of Mines and Geology, scale 1:750,000. 
Johnson, D.S., 1990, Depositional environment of the Upper Cretaceous Mokelumne River Formation, Sacramento Basin, California: American Association of Petroleum Geologists Bulletin, 74(5), $686 \mathrm{p}$.

Keller, M.A., 1995, Ventura Basin Province (013), in 1995 National assessment of United States oil and gas resources-results, methodology, and supporting data; Gautier, D. L., Dolton, G.L., Takahashi, K.I., and Varnes, eds.: U.S. Geological Survey Digital Data Series DDS-30, Release 2, 1 CD-ROM.

Lagoe, M.B., 1984, Paleogeography of the Monterey Formation, Cuyama Basin, California: American Association of Petroleum Geologists Bulletin, 68(5), p. 610-627.

Loomis, K.B., 1990, Depositional environments and sedimentary history of the Etchegoin Group, west-central San Joaquin Valley, California, in Structure, stratigraphy and hydrocarbon occurrences of the San Joaquin Basin, California; Kuespert, J.G., and Reid, S.A., eds.: Field Trip Guidebook 64-Pacific Section, Society of Economic Paleontologists and Mineralogists, p. 231246.

Magoon, L.B., 1995, Sonoma-Livermore Basin Province (008), in 1995 National assessment of United States oil and gas resources-results, methodology, and supporting data; Gautier, D. L., Dolton, G.L., Takahashi, K.I., and Varnes, eds.: U.S. Geological Survey Digital Data Series DDS-30, Release 2, 1 CD-ROM.

Magoon, L.B. and Valin, Z.C., 1995, Sacramento Basin Province (009), in 1995 National assessment of United States oil and gas resources-results, methodology, and supporting data; Gautier, D. L., Dolton, G.L., Takahashi, K.I., and Varnes, eds.: U.S. Geological Survey Digital Data Series DDS-30, Release 2, 1 CD-ROM.

Moore, D.W. and Nilsen, T.H., 1990, Upper Campanian and Lower Maestrichtian depositional systems, southern Sacramento Basin, California, in Sacramento Valley symposium and guidebook; Ingersoll, R.V., and Nilsen, T.H., eds.: Pacific Section of the Society of Economic Paleontologists and Mineralogists, $215 \mathrm{p}$.

Mukhopadhyay, B., 2002, Water-rock interactions in the basement beneath Long Valley Caldera; an oxygen isotope study of the Long Valley exploratory well drill cores: Journal of Volcanology and Geothermal Research, 116(3-4), p. 325-359.

Myer, L., and Birkinshaw, K, 2005, West Coast Regional Carbon Sequestration PartnershipQuarterly Report: DOE contract no. DE-FC26-032NT41984, 32 p.

Myer, L., Benson, S., Clinkenbeard, J., Downey, C., Zhang, H., and Herzog, H, 2005, An assessment of the geologic storage capacity of California sedimentary basins: paper presented at the Fourth Annual Conference on Carbon Capture and Sequestration, Department of Energy/National Energy Technology Laboratory, Alexandria, VA, May 2-5, 2005. 
Nilsen, T.H., 1979, Sedimentology of the Butano Sandstone, Santa Cruz Mountains, in Geology of the Santa Cruz Mountains, California; Nilsen, T.H., and Brabb, E.E., eds.: Cordilleran Section, Geological Society of America, Field Trip Guidebook, p. 30-39.

Nilsen, T., and Clarke, S.H., Jr., 1987, Geologic evolution of the late Cenozoic basins of northern California, in Tectonics, sedimentation, and evolution of the Eel River and associated coastal basins of northern California; Schymiczek, H., and Suchsland, R., eds.: Bakersfield, San Joaquin Geological Society Miscellaneous Publication 37, p. 15-29.

Norris, R.M., Webb, R.W., 1990, Geology of California (second edition): John Wiley \& Sons, New York, 365 p.

Ogle, B.A., 1968, Natural gas in Eel River Basin, Humboldt County, California, in Natural gases of North America-Pt. 1, Natural gases in rocks of Cenozoic age: American Association of Petroleum Geologists Memoir 1, p. 68-75.

Saltus, R. W., and Jachens, R. C., 1995, Gravity and basin-depth maps of the Basin and Range Province, Western United States, U.S. Geological Survey Geophysical Investigations Map GP 1012,1 sheet.

Schroeder, J.M., Lee, J., Owen, L.A., and Finkel, R.C., 2002, Quaternary dextral fault slip history along the White Mountains fault zone, California, in Geological Society of America, Cordilleran Section, $98^{\text {th }}$ annual meeting, Abstracts with programs, 34, $87 \mathrm{p}$.

Sheehan, J.R., 1987, The Owens Valley earthquake of 1872, in Geology and mineral wealth of the Owens Valley region, California: South Coast Geological Society Annual Field Trip Guidebook 15, p. 157-159.

Smoot, J.P., Litwin, R.J., Bischoff, J.L., and Lund, S.J., 2000, Sedimentary record of the 1872 earthquake and "tsunami" at Owens Lake, southeast California, in Seismoturbidites, seismites, and tsunamiites; Shiki, T., Cita, M.B., and Gorsline, D.S., eds., Sedimentary Geology, 135(1-4), p. 241-254.

Spitz, H.M., 1988, Structure of the Cox Trough, southeastern Cuyama Valley, southern California, in Field Trip Guidebook 59-Pacific Section; Bazeley, W.J.M., ed.: Society of Economic Paleontologists and Mineralogists, p. 113-126.

Stanley, R.G., 1995a, Central Coastal Province (011), in 1995 National assessment of United States oil and gas resources-results, methodology, and supporting data; Gautier, D.L., Dolton, G.L., Takahashi, K.I., and Varnes, K.L., eds.: U.S. Geological Survey Digital Data Series DDS30, Release 2, 1 CD-ROM.

Stanley, R.G., 1995b, Northern Coastal province (007), in 1995 National assessment of United States oil and gas resources-results, methodology, and supporting data; Gautier, D.L., Dolton, G.L., Takahashi, K.I., and Varnes, K.L., eds.: U.S. Geological Survey Digital Data Series DDS30, 1 CD-ROM. 
Teistworth, R.A., 1964, Geology and development of the Lathrop Gas Field, San Joaquin County, California: Selected Papers, San Joaquin Geological Society, v. 2, p. 19-29.

TenBrink, A.L., Cashman, P.H., Trexler, J.H., Joih, L. and Shahe, S., 2002, Active tectonism since $8 \mathrm{Ma}$ in the Sierra Nevada-Basin and Range transition zone, Lassen County, California, in Geological Society of America, Cordilleran Section, 98th annual meeting, Geological Society of America, 34:5, $100 \mathrm{p}$.

Tennyson, M.E., 1995, Santa Maria Basin province (012), in 1995 National assessment of United States oil and gas resources-results, methodology, and supporting data; Gautier, D. L., Dolton, G.L., Takahashi, K.I., and Varnes, eds.: U.S. Geological Survey Digital Data Series DDS-30, Release 2, 1 CD-ROM.

Wentworth, C.M., Fisher, G.R., Levine, P., and Jachens, R.C., 1995, The surface of crystalline basement, Great Valley and Sierra Nevada, California: a digital map database, U.S. Geological Survey Open-File Report 95-0096, 16 p.

Wilson, D.V., 1975, Geophysical investigation of the subsurface structure of Deep Springs Valley, California: Master's Thesis, University of California, Los Angeles.

Wood, P.R., 1960, Geology and ground-water features of the Butte Valley region, Siskiyou County, California: U.S. Geological Survey Water Supply Paper W 1491, 150 p.

Yerkes, R.F., McCulloch, T.H., Schoellhamer, J.E., and Vedder, J.G., 1965, Geology of the Los Angeles Basin, California-an introduction: U.S. Geological Survey Professional Paper 420-A, 57 p. 


\section{Acknowledgements}

The authors and PIER would like to thank the following individuals for their invaluable help in preparing this document:

For review of the Report content and editorial assistance:

Rick Blake - Lawrence Livermore National Laboratory

Ron Churchill - California Geological Survey

Chris Higgins - California Geological Survey

Larry Myer - UC Office of the President, California Institute for Energy and Environment

Mike Stetner - California Division of Oil, Gas, and Geothermal Resources

Chris Wills - California Geological Survey

For GIS support and cartographic design:

Milton Fonseca - California Geological Survey

\section{Glossary}

$\begin{array}{ll}\text { BBO } & \text { Billion Barrels of Oil } \\ \text { BCFG } & \text { Billion Cubic Feet of Gas } \\ \text { CCS } & \text { Carbon Capture and Sequestration } \\ \text { CGS } & \text { California Geological Survey } \\ \text { DOE } & \text { U.S. Department of Energy } \\ \text { DOG } & \text { California Division of Oil and Gas } \\ \text { DOGGR } & \text { California Division of Oil, Gas, and Geothermal Resources } \\ \text { EOR } & \text { Enhanced Oil Recovery } \\ \text { GIS } & \text { Geographic Information Systems } \\ \text { Gt } & \text { Gigaton (One Billion Metric Tons) } \\ \text { Gm } & \text { Giga (Billion) Cubic Meters } \\ \text { MBO } & \text { Thousand Barrels of Oil } \\ \text { MMBO } & \text { Million Barrels of Oil } \\ \text { MCF } & \text { Thousand Cubic Feet } \\ \text { MMCF } & \text { Million Cubic Feet } \\ \mathrm{m}^{3} & \text { Meters squared } \\ \mathrm{m}^{3} & \text { Cubic meters } \\ \mathrm{Mm}^{3} & \text { Mega (Million) Cubic Meters } \\ \text { TCFG } & \text { Trillion Cubic Feet of Gas } \\ \text { WESTCARB } & \text { West Coast Regional Carbon Sequestration Partnership }\end{array}$




\section{Appendix. Excluded Basins}

\begin{tabular}{|c|c|c|c|c|}
\hline Geoprovince & Basin Name & $\begin{array}{l}\text { Reason for } \\
\text { Exclusion }\end{array}$ & References & Comments \\
\hline Basin \& Range & Searles Valley & $\begin{array}{l}\text { In China Lake Naval } \\
\text { Weapons Station }\end{array}$ & Blakely \& Ponce, 2001 & $\begin{array}{l}\text { Thick areas only within China Lakes } \\
\text { Naval Station }\end{array}$ \\
\hline Basin \& Range & Indian Wells Valley & $\begin{array}{l}\text { In China Lake Naval } \\
\text { Weapons Station }\end{array}$ & & $\begin{array}{l}>60 \% \text { within China Lake Naval Weapons } \\
\text { Station }\end{array}$ \\
\hline Basin \& Range & Panamint Valley & See Comments & Blakely \& Ponce, 2001 & $\begin{array}{l}\text { Too small - Only } 12 \mathrm{~km}^{2} \text { of basin with fill } \\
>1.5 \mathrm{~km} \text { thick }\end{array}$ \\
\hline Basin \& Range & Saline Valley & $\begin{array}{l}\text { Within Death Valley } \\
\text { National Park }\end{array}$ & & $90 \%$ within Death Valley NP \\
\hline Basin \& Range & Eureka Valley & $\begin{array}{l}\text { Within Death Valley } \\
\text { National Park }\end{array}$ & & $80 \%$ within Death Valley NP \\
\hline Basin \& Range & Round Valley & $<1.0 \mathrm{~km}$. of fill & Saltus \& Jachens, 1995 & \\
\hline Basin \& Range & Deep Springs Valley & $<1.0 \mathrm{~km}$. of fill & Wilson, D.V., 1975 & $\begin{array}{l}122 \mathrm{~m}(400 \mathrm{ft}) \text { of valley fill and } 427 \mathrm{~m} \\
(1,400 \mathrm{ft}) \text { of alluvial fan material on } \\
\text { basement }\end{array}$ \\
\hline Basin \& Range & Adobe Valley & $<1.0 \mathrm{~km}$. of fill & Saltus \& Jachens, 1995 & \\
\hline Basin \& Range & Long Valley Caldera & See Comments & Mukhopadhyay, 2002 & $\begin{array}{l}\text { Tectonically active with } 50-150 \text { tons } \\
\text { CO2/ day escaping naturally }\end{array}$ \\
\hline Basin \& Range & Mono Basin & See Comments & & $\begin{array}{l}\text { Tectonically active and analogous to Long } \\
\text { Valley Caldera }\end{array}$ \\
\hline Basin \& Range & Bridgeport Valley & $<1.0 \mathrm{~km}$. of fill & Saltus \& Jachens, 1995 & \\
\hline Basin \& Range & Fish Lake Valley & $<1.0 \mathrm{~km}$. of fill & Blakely \& Ponce, 2001 & \\
\hline Basin \& Range & Death Valley & $\begin{array}{l}\text { Within Death Valley } \\
\text { National Park }\end{array}$ & & Entirely within Death Valley NP \\
\hline Basin \& Range & Greenwater Valley & $\begin{array}{l}\text { Within Death Valley } \\
\text { National Park }\end{array}$ & & $>90 \%$ in Death Valley NP \\
\hline Basin \& Range & Chicago Valley & $<1.0 \mathrm{~km}$. of fill & Blakely \& Ponce, 2001 & $\begin{array}{l}\text { Only small area of }<10 \mathrm{sq} . \mathrm{km} \text {. With } 1.0- \\
1.5 \mathrm{~km} \text {. of fill }\end{array}$ \\
\hline Basin \& Range & California Valley & $<1.0 \mathrm{~km}$. of fill & Blakely \& Ponce, 2001 & Only $4-5 \mathrm{sq} . \mathrm{km}$. With $1.0 \mathrm{~km}$. of fill \\
\hline Basin \& Range & Unnamed 12 & $\begin{array}{l}\text { Small basin with }< \\
0.5 \mathrm{~km} \text {. of fill }\end{array}$ & Blakely \& Ponce, 2001 & Small valley with $<0.5 \mathrm{~km}$. of fill \\
\hline Basin \& Range & Honey Lake Valley & $\begin{array}{l}\text { Within Sierra Army } \\
\text { Depot }\end{array}$ & Handman et al, 1990 & $\begin{array}{l}>50 \% \text { in Army Depot; only small area } \\
\text { north of Depot }>1.0 \mathrm{~km} \text {. }\end{array}$ \\
\hline Basin \& Range & Long Valley & See Comments & TenBrink et al, 2002 & $\begin{array}{l}\text { No apparent seals; thick sequence of } \\
\text { coarse sands \& diatomite }\end{array}$ \\
\hline Basin \& Range & Secret Valley & $<1.0 \mathrm{~km}$. of fill & CDWR, 2003 & $\begin{array}{l}\text { No deep control. CDWR strat log } \\
\text { indicates } 762 \mathrm{~m}(2500 \mathrm{ft} \text {.) of sediments }\end{array}$ \\
\hline Basin \& Range & Madeline Plains & $<0.5 \mathrm{~km}$. Of fill & CDWR, 2003 & \\
\hline Cascades & Shasta Valley & $<1.0 \mathrm{~km}$. of fill & $\begin{array}{l}\text { Chesterman \& } \\
\text { Saucedo, 1984; Mack, } \\
1960\end{array}$ & $\begin{array}{l}\text { Thin veneer of } \mathrm{Cz} \text { alluium. \& glacial } \\
\text { deposits on basement }\end{array}$ \\
\hline Coast Ranges & Santa Maria Basin & See Comments & & $\begin{array}{l}\text { Almost all perm and porosity in fractured } \\
\text { Monterey Shale }\end{array}$ \\
\hline Coast Ranges & Sargent Hollister Basin & $\begin{array}{l}\text { Small active fault } \\
\text { controlled basin }\end{array}$ & & $\begin{array}{l}\text { Narrow basin bounded by active San } \\
\text { Andreas and Calaveras faults }\end{array}$ \\
\hline Klamath Mountains & Scott Valley & $<120 \mathrm{~m}(400 \mathrm{ft})$ & Mack, 1958 & $\begin{array}{l}\text { Maximum of } 120 \mathrm{~m}(400 \mathrm{ft}) \text { of alluvium } \\
\text { on basement }\end{array}$ \\
\hline Modoc Plateau & Butte Valley & $<1.0 \mathrm{~km}$. of fill & $\begin{array}{l}\text { Wood, 1960; Adam et } \\
\text { al, } 1994\end{array}$ & $\begin{array}{l}\text { Basalt/ andesite basement overlain by } \\
\text { veneer of glacial alluvium and lacustrine } \\
\text { sediments }\end{array}$ \\
\hline Modoc Plateau & Klamath Valley & $<1.0 \mathrm{~km}$. of fill & $\begin{array}{l}\text { Sammel, \& Peterson, } \\
1976\end{array}$ & $\begin{array}{l}\text { Gravity shows portion in Southern } \\
\text { Oregon to be up to } 2.0 \mathrm{~km} \text {. Deep, but } \\
\text { thins into CA }\end{array}$ \\
\hline Mojave Desert & Unnamed 1 & $<1.0 \mathrm{~km}$. of fill & Saltus \& Jachens, 1995 & Small basin with $<1.0 \mathrm{~km}$. fill \\
\hline Mojave Desert & Unnamed 2 & $\begin{array}{l}\text { Within Chocolate } \\
\text { Mt. Gunnery Range }\end{array}$ & & \\
\hline Mojave Desert & Pinto Basin & $\begin{array}{l}\text { Within Joshua Tree } \\
\text { National Park }\end{array}$ & & \\
\hline Mojave Desert & Rice Valley & $<1.0 \mathrm{~km}$. of fill & Saltus \& Jachens, 1995 & \\
\hline Mojave Desert & Clipper Valley & Within Mojave & & \\
\hline
\end{tabular}




\begin{tabular}{|c|c|c|c|c|}
\hline Geoprovince & Basin Name & $\begin{array}{l}\text { Reason for } \\
\text { Exclusion }\end{array}$ & References & Comments \\
\hline & & National Park & & \\
\hline Mojave Desert & Fenner Valley & $<1.0 \mathrm{~km}$. of fill & Saltus \& Jachens, 1995 & North half in Mojave NP \\
\hline Mojave Desert & Unnamed 3 & $\begin{array}{l}\text { Within Mojave } \\
\text { National Park }\end{array}$ & & More than $50 \%$ in Mojave NP \\
\hline Mojave Desert & Cadiz Valley & $<1.0 \mathrm{~km}$. of fill & Saltus \& Jachens, 1995 & \\
\hline Mojave Desert & Unnamed 4 & $<0.5 \mathrm{~km}$. of fill & Saltus \& Jachens, 1995 & Small valley with $<0.5 \mathrm{~km}$. \\
\hline Mojave Desert & Dale Lake Valley & $<1.0 \mathrm{~km}$. of fill & Saltus \& Jachens, 1995 & \\
\hline Mojave Desert & Unnamed 5 & $\begin{array}{l}\text { Within Twentynine } \\
\text { Palms Marine Base }\end{array}$ & & $60 \%$ within Marine base \\
\hline Mojave Desert & Unnamed 6 & $\begin{array}{l}\text { Within Twentynine } \\
\text { Palms Marine Base }\end{array}$ & & $>50 \%$ within Marine base. \\
\hline Mojave Desert & Unnamed 7 & $\begin{array}{l}\text { Small basin with }< \\
0.5 \mathrm{~km} \text {. of fill }\end{array}$ & Saltus \& Jachens, 1995 & \\
\hline Mojave Desert & Johnson Valley & $\begin{array}{l}\text { Small basin with }< \\
0.5 \mathrm{~km} \text {. of fill }\end{array}$ & Saltus \& Jachens, 1995 & \\
\hline Mojave Desert & Lucerne Valley & $\begin{array}{l}\text { Small basin with }< \\
0.5 \mathrm{~km} \text {. of fill }\end{array}$ & Saltus \& Jachens, 1995 & \\
\hline Mojave Desert & North Lucerne Valley & $\begin{array}{l}\text { Small basin with }< \\
0.5 \mathrm{~km} \text {. of fill }\end{array}$ & Saltus \& Jachens, 1995 & \\
\hline Mojave Desert & El Mirage Valley & $<1.0 \mathrm{~km}$. of fill & Saltus \& Jachens, 1995 & \\
\hline Mojave Desert & Apple Valley & $<1.0 \mathrm{~km}$. of fill & Saltus \& Jachens, 1995 & \\
\hline Mojave Desert & Brisbane Valley & $<1.0 \mathrm{~km}$. of fill & Saltus \& Jachens, 1995 & \\
\hline Mojave Desert & Hinkley Valley & $<1.0 \mathrm{~km}$. of fill & Blakely \& Ponce, 2001 & \\
\hline Mojave Desert & Unnamed 8 & $<1.0 \mathrm{~km}$. of fill & Blakely \& Ponce, 2001 & \\
\hline Mojave Desert & Silurian Valley & $<1.0 \mathrm{~km}$. of fill & Blakely \& Ponce, 2001 & \\
\hline Mojave Desert & China Ranch Basin & $<1.0-1.5 \mathrm{~km}$. of fill & Blakely \& Ponce, 2001 & $\begin{array}{l}\text { Only about } 14 \mathrm{sq} . \mathrm{km} \text {. with } 1.0-1.5 \mathrm{~km} \text {. of } \\
\text { fill }\end{array}$ \\
\hline Mojave Desert & Valjean Valley & $\begin{array}{l}\text { Small basin with }< \\
0.5 \mathrm{~km} \text {. of fill }\end{array}$ & Blakely \& Ponce, 2001 & \\
\hline Mojave Desert & Unnamed 9 & $\begin{array}{l}\text { Within Mojave } \\
\text { National Park }\end{array}$ & & $>50 \%$ within Mojave NP \\
\hline Mojave Desert & Unnamed 10 & $\begin{array}{l}\text { Within Mojave } \\
\text { National Park }\end{array}$ & & Entirely within Mojave NP \\
\hline Mojave Desert & Shadow Valley & $\begin{array}{l}\text { Within Mojave } \\
\text { National Park }\end{array}$ & & $\begin{array}{l}>75 \% \text { within Mojave NP and } 0 \% \text { with }> \\
0.5 \mathrm{~km} \text {. of fill }\end{array}$ \\
\hline Mojave Desert & Antelope Valley & $<1.0 \mathrm{~km}$. of fill & Saltus \& Jachens, 1995 & Large valley with $<0.5 \mathrm{~km}$. \\
\hline Mojave Desert & Unnamed 11 & $<1.0 \mathrm{~km}$. of fill & Blakely \& Ponce, 2001 & Small basin with $<1.0 \mathrm{~km}$. \\
\hline Mojave Desert & Almond Cove Basin & $<1.0 \mathrm{~km}$. of fill & Saltus \& Jachens, 1995 & $\begin{array}{l}\text { Very small area of } 2.0 \mathrm{~km} \text { fill per Blakely } \\
\text { \& Ponce (2001) }\end{array}$ \\
\hline Mojave Desert & Pilot Knob Valley & $\begin{array}{l}\text { In China Lake Naval } \\
\text { Weapons Station }\end{array}$ & & $\begin{array}{l}\text { Entirely within China Lake Naval } \\
\text { Weapons Station }\end{array}$ \\
\hline Mojave Desert & Goldstone Basin & $\begin{array}{l}\text { In China Lake Naval } \\
\text { Weapons Station } \\
\end{array}$ & & $\begin{array}{l}>90 \% \text { in China Lake Naval Weapons } \\
\text { Station }\end{array}$ \\
\hline Mojave Desert & Ivanpah Valley & $\begin{array}{l}\text { Within Mojave } \\
\text { National Park }\end{array}$ & & $90 \%$ in Mojave NP \\
\hline Mojave Desert & Lanfair Valley & $\begin{array}{l}\text { Within Mojave } \\
\text { National Park }\end{array}$ & & \\
\hline Mojave Desert & Needles Valley & $\begin{array}{l}<1.0 \mathrm{~km} . \text { of fill in } \\
\mathrm{CA}\end{array}$ & Saltus \& Jachens, 1995 & $\begin{array}{l}\text { Up to } 3.5 \mathrm{~km} \text {. of fill just east of state line } \\
\text { in NV }\end{array}$ \\
\hline Mojave Desert & Chemehuevi Valley & $<1.0 \mathrm{~km}$. of fill & Saltus \& Jachens, 1995 & \\
\hline Mojave Desert & Vidal Valley & $<0.5 \mathrm{~km}$. of fill & Saltus \& Jachens, 1995 & \\
\hline Mojave Desert & Unnamed 13 & $\begin{array}{l}\text { Within Mojave } \\
\text { National Park }\end{array}$ & & Entirely within Mojave NP \\
\hline Mojave Desert & Unnamed 14 & $<1.0 \mathrm{~km}$. of fill & $\begin{array}{l}\text { Saltus and Jachens, } \\
1995\end{array}$ & Small basin with $<1.0 \mathrm{~km}$. of fill \\
\hline Mojave Desert & Unnamed 15 & $<0.5 \mathrm{~km}$. of fill & \begin{tabular}{|l} 
Saltus and Jachens, \\
1995
\end{tabular} & Very small basin with $<0.5 \mathrm{~km}$. of fill \\
\hline Mojave Desert & Unnamed 16 & $<0.5 \mathrm{~km}$. of fill & $\begin{array}{l}\text { Saltus and Jachens, } \\
1995\end{array}$ & Very small basin with $<0.5 \mathrm{~km}$. of fill \\
\hline
\end{tabular}




\begin{tabular}{|c|c|c|c|c|}
\hline Geoprovince & Basin Name & $\begin{array}{l}\text { Reason for } \\
\text { Exclusion }\end{array}$ & References & Comments \\
\hline Mojave Desert & Unnamed 17 & $<0.5 \mathrm{~km}$. of fill & $\begin{array}{l}\text { Saltus and Jachens, } \\
1995\end{array}$ & Very small basin with $<0.5 \mathrm{~km}$. of fill \\
\hline Mojave Desert & Unnamed 18 & $<0.5 \mathrm{~km}$. of fill & $\begin{array}{l}\text { Saltus and Jachens, } \\
1995\end{array}$ & Very small basin with $<0.5 \mathrm{~km}$. of fill \\
\hline Mojave Desert & Unnamed 19 & $\begin{array}{l}\text { Within Twentynine } \\
\text { Palms Marine Base }\end{array}$ & & $70 \%$ within Marine Base \\
\hline Peninsular Ranges & Moreno Valley & $<0.5 \mathrm{~km}$. of fill & $\begin{array}{l}\text { Saltus and Jachens, } \\
1995\end{array}$ & \\
\hline Peninsular Ranges & Perris Valley & $<0.5 \mathrm{~km}$. of fill & $\begin{array}{l}\text { Saltus and Jachens, } \\
1995\end{array}$ & \\
\hline Peninsular Ranges & Diamond Valley & $<0.5 \mathrm{~km}$. of fill & $\begin{array}{l}\text { Saltus and Jachens, } \\
1995\end{array}$ & \\
\hline Peninsular Ranges & San Jacinto Basin & $\begin{array}{l}\text { Small, seismically } \\
\text { active basin }\end{array}$ & $\begin{array}{l}\text { Lee et al, 1996; Fett, } \\
\text { 1968; Thatcher et al; } \\
1975\end{array}$ & $\begin{array}{l}\text { Basin in most seismically active part of } \\
\text { southern San Andreas Fault system. Only } \\
\text { very small area with }>1.0 \mathrm{~km} \text {. of fill }\end{array}$ \\
\hline Peninsular Ranges & Temecula Valley & $<1.0 \mathrm{~km}$. of fill & $\begin{array}{l}\text { Saltus and Jachens, } \\
1995\end{array}$ & \\
\hline Sierra Nevada & Sierra Valley & $<1.0 \mathrm{~km}$. of fill & Jackson et al, 1961 & $\begin{array}{l}\text { Cenozoic deposits at least } 760 \mathrm{~m}(2500 \mathrm{ft}) \\
\text { thick in deepest part }\end{array}$ \\
\hline
\end{tabular}

